A BIBLIOGRAPHY

RELATING TO THE

GEOLOGY, PALEONTOLOGY, $\triangle N D$

MINERAL RESOURCES

or

CALIFORNIA

ANTHONY W. VOGDRS 


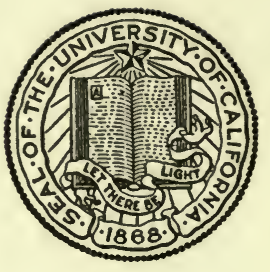

THE LIBRARY

OF

THE UNIVERSITY

OF CALIFORNIA

DAVIS 






\section{' CALIFORNIA STATE MINING BUREAU.}

J. J. CRAWFORD, State Mineralogist.

BULLETIN No. $10 . \quad$ San Francisco, September, 1896.

\section{A BIBLIOGRAPHY}

RELATING TO THE

\section{Geologi,Palmontologi, and Mineral Ressources}

OF

\section{CALI.FORNIA.}

By ANTHONY W. VOGDES, Captain Fifth Artillery, U. S. A.,

Fellow American Geological Society, American Association for the Advancement of Science; Member of the New York Academy of Sciences; also of the Georgia, Philadelphia, Chicago, and California Academies of Natural Sciences.

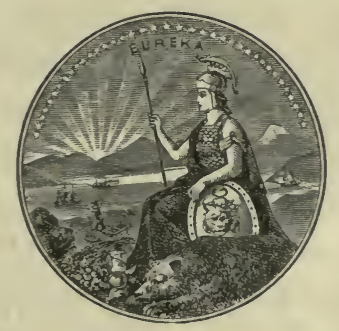

SACRAMENTO:

A. J. Johnston, : : : : : : SUPT. STATE PRINTING. 1896 .

LIBRARY 



\section{CONTENTS.}

INTRODUCTION, WITH LETTER OF TRANSMITTAL TO STATE

PART I.

Publications of the State of California.

PUBLICATIONS OF THE FIRST GEOLOGICAL SURVEY OF CALIFORNIA (JOHN B. TRASK, STATE GEOLOGIST) ............. 1 SURVEYOR-GENERAL'S REPORTS .................................. 3 PUBLICATIONS OF THE SECOND GEOLOGICAL SURVEY OF

CALIFORNIA (J. D. WHITNEY, STATE GEOLOGIST).......... 3 PUBLICATIONS OF CALIFORNIA STATE MINING BUREAU ..... 13 CALIFORNIA SENATE AND ASSEMBLY DOCUMENTS ............ 18 CALIFORNIA STATE UNIVERSITY PUBLICATIONS ..... .......... 19

PART II.

\section{Publications of the United States Government.}

REPORTS OF THE SECRETARY OF WAR ....................... 26

U. S. NAVY DEPARTMENT _...................................... 29

REPORTS OF EXPLORATIONS AND SURVEYS ................... 29

REPORTS OF MINERAL RESOURCES OF THE STATES AND

TERRITORIES WEST OF THE MISSISSIPPI.................... 33

REPORTS TO UNITED STATES MINT ............ ................. 36

UNITED STATES CENSUS REPORTS-10TH AND 11TH ........... . 37

UNITED STATES GEOGRAPHICAL AND GEOLOGICAL SURVEYS

WEST OF THE 100TH MERIDIAN ............................. 38

UNITED STATES GEOLOGICAL AND GEOGRAPHICAL SURVEYS

OF THE TERRITORIES ...................................... 39

UNITED STATES GEOLOGICAL SURVEY ......................... 39 
PART III.

Publications of Scientific Societies, and Periodicals.

AMERICAN ASSOCIATIONS FOR THE ADVANCEMENT OF

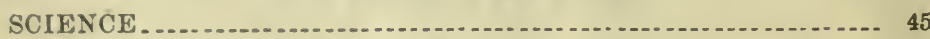

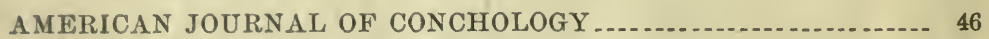

AMERICAN NATURALIST..................................... 47

INTERNATIONAL CONGRESS OF GEOLOGISTS, AMERICAN COM-

MITTEE REPORTS, 1888 .................................... 48

AMERICAN GEOLOGIST . .........

AMERICAN JOURNAL OF SCIENCE AND ARTS................... 50

AMERICAN MINING GAZETTE ................................ 57

ANNALS OF THE NEW YORK LYCEUM OF NATURAL HISTORY.. 58

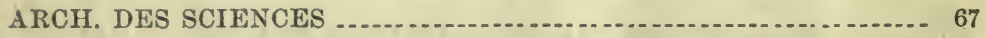

BRITISH ASSOCIATIONS REPORTS ............................. 68

BULLETINS OF THE GEOLOGICAL SOCIETY OF AMERICA ...... 58

BULLETINS GEOLOGICAL SOCIETY DE FRANCE................. 68

CALIFORNIA ACADEMY OF SCIENCES ............................ 61

COMPTES RENDUS DE L'ACADÉMIE DES SCIENCES.. ............ 67

FOREIGN SOCIETIES.................................................. 67

FRANKLIN INSTITUTE JOURNAL AND AMERICAN MECHANICS

MAGAZINE ...................................................... 69

GEOLOGICAL MAGAZINE......................................... 67

HUTCHINGS'S ILLUSTRATED CALIFORNIA MAGAZINE ......... 69

HUNT'S MERCHANTS' MAGAZINE .............................. 69

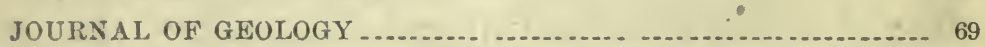

JOURNAL OF GEOLOGICAL SOCIETY OF LONDON ............... 67

MINING MAGAZINE............................................ 70

MINING AND SCIENTIFIC PRESS............................... 71

MONATSBER K. PREUSS. AKAD. WISS. BERLIN . .......... . . . . ... 67

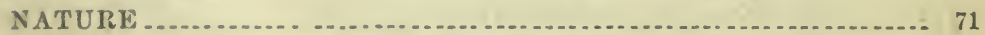

NEWPORT NATURAL HISTORY SOCIETY _.................... 73

NEW YORK ACADEMY OF SCIENCE .......................... 71

NEUES JAHRBUCH MINERALOGIE GEOL. PALAONTOLOGIE _.67-68 OVERI.AND MONTHLY ........................................... 72

PHARMACEUTICAI, JOURNAL _............................ 72

PHIIOSOPHICAL SOCIETY OF' WASHINGTON................. 72 
- Page.

PHILADELPHIA ACADEMY OF NATURAL SCIENCES .......... 73

PUBLICATIONS OF UNITED STATES NATIONAI, MUSEUM ...... 75

SANTA BARBARA SOCIETY OF NATURAL HISTORY ........... 76

ST. LOUIS ACADEMY OF SCIENCES ......................... 76

SCIENCE . . . .

SCHOOL OF MINES, COLUMBIA COLLEGE _.................... . 78

WEST AMERICAN SCIENTIST _... . .

TRANSACTIONS ALBANY INSTITUTE........................ 79

TRANSACTIONS EDINBURGH GEOLOGICAL SOCIETY ........ .... 68

TRANSACTIONS AMERICAN INSTITUTE OF MINING ENGINEERS 79

VERHANDL K. K. GEOL. REICHSANSTALT ...................... 68

VERHANDL. DER RUSSICH KAISERLICHEN MINERALOGIS-

CHEN GESELLSCHAFT ZU ST. PETERSBURG ................. 69

ZOE $\ldots \ldots \ldots$

PART IV.

Publications of State Geological Surveys other than that of California.

REPORTS MISSOURI GEOLOGICAL SURVEY 81

\section{PART V.}

Miscellaneous Publications.

ALPHABETICAL LIST 



\section{LETTER OF TRANSMITT'AL.}

Hon. J. J. Crawford, State Mineralogist:

I have the honor to submit this bibliography for publication by the State Mining Bureau, with the following brief remarks:

The literature relating to the natural resources of California is widely scattered, and, to a great extent, inaccessible to any one but the specialist.

The few descriptions of fossils printed in the State Geological Reports were issued nearly thirty years ago. Since that date a large number of papers on geology, palæontology, and descriptions of local mining regions have appeared, either in the transactions of learned societies or in special publications with but a limited distribution. In many cases these descriptions have been brief, and those of fossils without illustrations.

Besides these, there are many articles incorporated in the official publications of the United States, and in volumes whose very existence is almost unknown to the general reader.

I have labored to bring this mass of literature together and make it accessible to the student and general reader. Some may ask, What is the advantage of such a catalogue? But let them take up any special line of investigation, and the first thing wanted will be a list of books of reference to know what has been published on the subject.

To the compiler such compilations are dry and laborious, and many think afterward I could do better; but let all those who think so, labor to improve this catalogue.

The palæontologist has to deal with the different species under each genus. I have, therefore, included a full list of fossils under each reference, which will save the student many a weary 
hour of laborious research through many volumes and transactions of learned societies.

The catalogue has been arranged under different heads, such as State geological reports, transactions of learned societies, etc., which will give the student a direct reference to the contents of different publications.

The palæontology of California differs greatly from that of the Atlantic States in the existence of an extensive bed of the Tertiary formation, with but few of the older formations, indicating that the elevation of the Pacific Coast was chiefly made since the Mesozoic age, and a great part of it as late as the Quaternary. Nearly all the coast ranges and the low foothills of the Sierra Nevada are covered with thick beds which contain fossils identical with living species, with others extinct along the Californian shores, but living farther to the north or south.

To make a complete catalogue, works on recent conchology of the Pacific Coast should be included, but the author has deemed it best to omit the most of them.

Part IV of the catalogue contains an alphabetical list of miscellaneous publications. Many of them are references to early reports on gold and other minerals, including trips to the gold fields of California. All of these are not strictly geological reports, but now and then they contain valuable references to local geology. The author regrets that he has been unable to give many notes in this part, most of the works being inaccessible.

ANTHONY W. VOGDES.

Fort Mason, San Francisco, Cal., September 1, 1896. 


\title{
A BIBLIOGRAPHY
}

\author{
RELATING TO THE
}

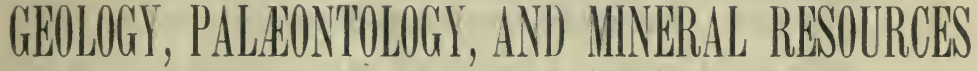

\section{OF CALIFORNTA.}

\section{PART I.}

\section{Publications of the State of California.}

\section{FIRS'T GEOLOGICAL SURVEY OF CALIFORNIA.}

\author{
Dr. JOHN B. TRASK, State Geologist.
}

Report of the Special Committee in favor of a Geological Survey of California. Submitted by Mr. Randall, April 24, 1851. $19 \mathrm{pp}$.

Report of 1853, Geology of the Sierra Nevada or California Range; by John B. Trask. Sacramento, 1853. 31 pp. (2,000 copies printed.)

Report on the Geology of the Coast Mountains, embracing their agricultural resources and mineral productions, also portions of the Middle and Northern Mining Districts; by Dr. John B. Trask, State Geologist. Senate Doc. No. 14. Sacramento, $1855.95 \mathrm{pp}$.

This report contains a description of the physical geography of the coast mountains; geology of the coast mountains; Tertiary rocks of the coast mountains; primitive rocks of the coast mountains; volcanic rocks of the coast mountains; geology of the San Bernardino Mountains; stratified rocks of the San Bernardino chain and plains of Los Angeles; extent of the infusorial group; plains of Los Angeles; artesian borings; soils and productions of Los Angeles; mineral pro- 
ductions of Los Angeles; country north of the American River; mineral district of the upper Sacramento Valley; geology of the northern coast mountains; local geology of the northern coast mountains; Carboniferous limestone of the eastern part of shasta County; Trinity County; structure of the Sacramento Valley; Tertiary rocks and other deposits of the Sierra Nevada; placer mining; quartz veins; quartz mines, with descriptions of mines, and statistics.

Report on the Geology of the Coast Mountains and part of the Sierra Nevada, embracing their industrial resources in agriculture and mining; by Dr. John B. Trask, State Geologist. Assembly Doc. No. 9, Session of 1854. 92 pp.

This report contains a description of the geology of the Monte Diablo range, Salinas Valley, from Point Pinos to the Nacimiento River, Santa Cruz Mountains; structure of the valleys of Sacramento and San Joaquin; review of the geological changes in the coast mountains and Monte Diablo range; classification of the rocks of the coast mountains and Monte Diablo range; position and relation of the volcanic rocks to the Tertiaries; volcanic rocks preceding the Tertiary era; most recent volcanic rocks of the coast mountains; changes of level and river terraces; soils of the valley Santa Clara and shores of the Bay of San Francisco; valley of the Salinas; soils of the Salinas; Pajaro Valley; Livermore Valley; mineral resources of the coast mountains; mineral districts, embracing parts of the counties of Nevada, Placer, El Dorado, and Calaveras; quartz veins, and their relative age in California; character and position of the older veins below the surface; present government of metallic veins; descriptions of mines, with list of gold mines.

Report on the Geology of Northern and Southern California, embracing the mineral and agricultural resources of those sections; with statistics of the Northern, Southern, and Middle mines; by Dr. John B. Trask. Assembly Doc. No. 14, Session of $1856.66 \mathrm{pp}$.

This report contains a description of the physical geography lying in the coast mountains north of the Bay of San Francisco; geological structure of the coast mountains; mineral character of the primitive rocks of the coast mountains; soils of Petaluma County ; plains west of the Sacramento River; San Bernardino; geology of Table Mountain, Tuolumne County; Carboniferous rocks of the Northern district; salines of the upper Sacramento Valley; Mammoth Mines Seventy-six, Jamison Creek; descriptions of mines, etc.; analysis of saline waters from Lick Springs, Shasta County; gold mines in operation in 1855 ; table of altitudes. 


\section{SURVEYOR-GENERAL REPORTS.}

Geology of a part of Calaveras County. December, 1854. By

William Patton. In Report to the Surveyor-General of California; Document No. 5, Appendix F, pp. 86-88. Sacramento, 1855.

The tract noticed embraces an extent of the county between the Moquelumne River and Middle Fork, and the Stanislaus and North Fork, longitudinally; and latitudinally, the space between the foothills and the headwaters of the San Antonio branch of the Calaveras.

Report of a survey of a portion of the eastern boundary of California, and a reconnoissance of the old Carson and Johnson immigrant roads over the Sierra Nevada. In Annual Report of the Surveyor-General, 1856; Assembly Document No. 5, Session of 1856, pp. 91-186.

This report, by George H. Goddard, contains a few geological notes on rocks along the route.

\section{SECOND GEOLOGICAL SURVEY OF CALI- FORNIA.}

J. D. WHITNEY, State Geologist.

The Geological Survey of California. An address delivered before the Legislature of California, at Sacramento, Tuesday evening, March 12, 1861, by J. D. Whitney, State Geologist. To which is appended a copy of the Act authorizing the survey. San Francisco, 1861. 50 pp.

Letter of the State Geologist relative to the progress of the State Geological Survey, by J. D. Whitney. San Francisco, 1862. $7 \mathrm{pp}$.

Lecture on Geology, delivered before the Legislature of California, at San Francisco, Tuesday evening, February 27, 1862, by J. D. Whitney. San Francisco, 1862. 33 pp.

Lecture on Geology, delivered before the Legislature of California, at Sacramento, Tuesday evening, March 19, 1863, by J. D. Whitney. Sacramento, 1863. $17 \mathrm{pp}$. 
Annual Report of the State Geologist of California for the year 1862. Sacramento, 1862. $12 \mathrm{pp}$.

Annual Report of the State Geologist for the year 1863. Sacramento, 1864. 7 pp.

Letter of the State Geologist, relative to the progress of the State Geological Survey during the years 1864-65, by J. D. Whitney. Sacramento, 1866. $14 \mathrm{pp}$.

Letter of the State Geologist, relative to the progress of the State Geological Survey during the years 1866-67, by J. D. Whitney. Sacramento, 1867. $15 \mathrm{pp}$.

An Address on the propriety of continuing the State Geological Survey of California, delivered before the Legislature, January, 1868, by J. D. Whitney. San Francisco, 1868. $23 \mathrm{pp}$.

Report of the State Geologist on the condition of the Geological Survey of California, by J. D. Whitney. Sacramento, 1869. $7 \mathrm{pp}$.

Letter of the State Geologist relative to the progress of the Geological Survey during the years 1870-71. Sacramento, 1871. $13 \mathrm{pp}$.

Statement of the progress of the State Geological Survey of California during the years $1872-73$, by J. D. Whitney. Sacramento, 1873. $14 \mathrm{pp}$.

Report of the Joint Committee on the Geological Survey of the State, made to the Legislature in 1874.

Report of sub-committee of the Committee on Mines and Mining Interests of the Senate, concerning the State Geological Survey. Sacramento, $1866.5 \mathrm{pp}$.

Mining Statistics, No. 1. Tabular statement of the condition of the auriferous quartz mines and mills in that part of Mariposa and Tuolumne Counties lying between the Merced and Stanislaus Rivers; by A. Rémond. April, 1866. $16 \mathrm{pp}$. 
The Yosemite Book. A description of the Yosemite Valley and the adjacent regions of the Sierra Nevada and Big Trees of California. New York, 1868. pp. 4 to 116. 2 maps and 28 photographs. 4to. (250 copies printed.)

Another edition. Cambridge, 1870 . viii and 155 pp., and 2 maps.

Another edition. Cambridge, 1871. vii and 133 pp., and 2 maps.

Another edition, revised and corrected. Cambridge, 1874. viii and $186 \mathrm{pp}$., and 4 maps.

Geographical catalogue of the Mollusca found west of the Rocky Mountains, between latitudes $33^{\circ}$ and $49^{\circ}$; by J. G. Cooper. San Francisco, 1867. 40 pp.

This catalogue was based on that published by P. P. Carpenter, Brit. Assoc. Adv. Sci., 1863, with the addition of about 130 species.

Catalogue of the Invertebrate Fossils of the Western Slope of the United States, Part II ; by J. G. Cooper. San Francisco, 1871. $39 \mathrm{pp}$.

This catalogue was intended merely as a check-list and for labels; supplementing the catalogue published in 1867.

The author gives a list of the Post Pliocene, Pliocene, and Miocene fossils described in detail in "Palæontology of California."

Palæontology, Vol. 1. Carboniferous and Jurassic fossils, by F. B. Meek. Triassic and Cretaceous fossils; by W. M. Gabb. Philadelphia, 1864. xx and 243 pp. 32 plates.

The following fossils are described and illustrated in this volume:

\section{CARBONIFEROUS-}

Foraminifera - Fusulina robusta, Meek; $F$. gracilis, Meek; $F$. cylindrica, Fischer?

ZoöPHҮTA-Lithostrotion mamillare \&, Castlenau; L. Californiense, Meek; L. sp.?; Clisiophyllum Gabbi, Meek.

BrachIOPODA-Orthis (sp. undt.); Productus semireticulatus, Martin; Rhynchonella (sp. undt.); Spirifer lineatus, Martin ?; Spiriferina (sp. undt.); Retzia compressa, Meek.

Gasteropoda-Euomphalus Whitneyi, Meek.

Triassic fossils of California and adjacent Territories; by W. M. Gabb.

Orthoceratites Blakei, n.sp.; Nautilus Whitneyi, n.sp.; N. multicameratus, n.sp.; Goniatites lævidorsatus, Hauer; Ceratites Haidingeri, Hauer; C. Whitneyi, n.sp.; Ammonites Blakei, n.sp.; A. ausseanus, Hauer; A. Homfrayi, n.sp.; A. Billingsianus, n.sp.; A. Ramsaueri?, 
Quenst; Myacites (Panopœa?) Humboldtensis, n.sp.; Panopoa? Rémondi; Corbula Blakei, n.sp.; Mytilus Homfrayi, n.sp.; Avicula Homfrayi, n.sp.; A. macronata, n.sp.; IIalobia? dubia, n.sp.; Monotis subcircularis, n.sp.; Rhynchopterus, n.gen.; R. obesus, n.sp.; Posidonomya stella, n.sp.; P. Daytonensis, n.sp.; Myophoria alta, n.sp.; Pecten deformis, n.sp.; Terebratula Humboldtensis, n.sp.; Rhynchonella lingulata, n.sp.; $R$. æquiplicata, n.sp.; Spirifer Homfrayi, n.sp.

\section{Jurassic fossils; by F. B. Meek.}

Rhynchonella gnathophora, Meek; Terebratula sp.?; Gryphoea sp.?; Lima? sinuata, Meek; L. recticostata, Meek; L.? cuneata, Meek; Pecten acutiplicatus, Meek; Inoceramus? obliquus, Meek; I.? rectangulus, Meek; Trigonia pandicosta, Meek; Mytilus multistriatus, Meek; Astarte ventricosa, Meek; Unicardium? gibbosum, Meek; Myacites depressus, Meek; Belemnites sp.?

\section{Cretaceous fossils, by W. M. Gabb.}

\section{Crustacea-Callianassa Stimpsoni, n.sp.}

CePHALOPODA-Belemnites impressus, n.sp.; Nautilus Texanus?, Shum.; Aturia Mathewsoni, n.sp.; Ammonites subtricarinatus, D'Orb; A. Newberryanus, Meek; A. Breweri, n.sp.; A. Haydeni, n.sp.; $A$. Peruvianus, DeBuch?; A. Traski, n.sp.; A. ramosus, Meek; A. Hoffmani, n.sp.; A. Rémondi, n.sp.; A. Batesi, Trask; A. Chicoensis, Trask; A. complexus, H. \& M.?; ? A. Cooperi, n.sp.; Hamites Vancouverensis, n.sp.?; Helicoceras vermicularis, n.sp.; H. Breweri, n.sp.; H. declive, n.sp.; Turrilites (sp. undt.); Ptychoceras æquicostatus, n.sp.; P. (? Hamites) quadratus, n.sp.; Crioceras (Ancyloceras?) Remondi, n.sp.; C. latus, n.sp.; C. percostatus, n.sp.; Ancyloceras (sp. undt.); Baculites Chicoenis, Trask; B. (sp. undt.).

Gasteropoda-Typhis antiquus, n.sp.; Fusus Martinez, n.sp.; $F$. Matthewsoni, n.sp.; F. Averilli, n.sp.; F. diaboli, n.sp.; F. aratus, n.sp.; F. flexuosus, n.sp.; F. Kingi, n.sp.; F. Californicus, Conrad; subgen. Hemifusus; Fusus (Hemifusus) Horni; F. (H.) Cooperi, n.sp.; F. (H.) Rémondi, n.sp.; cf. Pyrula penita, Conrad ; Neptunea curvirostris, n.sp.; N. ponderosa, n.sp.; N. perforata; \& N. supraplicata, n.sp.; N.IIoffmani, n.sp.; N. gracilis, n.sp.; Perissolax brevirostris, n.sp.; P.Blakei, Conrad ; Turris Claytonensis, n.sp.; T' (sub.gen. Drillia) varicostata, n.sp.; Cordiera microptygma, n.sp.; Tritonium Horni, n.sp.; T. Diegoensis, n.sp.; T. paucivaricatum, n.sp.; Cancellaria (Heilprin, Ter. Geol., p. 113; badly figured); T. Whitneyi, n.sp.; Buccinum liratum, n.sp.; Nassa cretacea, n.sp.; N. antiquata, n.sp.; Haydenia, n.gen.; II. impressa, n.sp.; Pseudoliva lineata, n.sp.; $P$.volutieformis, n.sp.; Olivella Mathewsoni, n.sp.; Ancillaria elongata, n.sp.; ? Fasciolaria leviuscula, n.sp.; F. sinuata, n.sp.; ? F. Io., n.sp.; Volutilithes Navarroensis, Shum.; Mitra cretacea, n.sp.; Whitneya, n.gen.; W. ficus, n.sp.; Morio (sub.gen. Sconsia); M. tuberculatus, n.sp.; Ficus?; $F$. cypræoides, n.sp.; Lunatia avellana, n.sp.; L. Shumardiana, n.sp.; L. Horni, n.sp.; L. nuciformis, n.sp.?; $L$. (Gyrodes?) Conradiana, n.sp.; Gyrodes expansa, n.sp.; Neverita secta, n.sp.; Naticina obliqua, n.sp.; (Sigaretus, Heilprin Ter. Geol., p. 113); Amauropsis oviformis, n.sp.; A.alveata, n.sp.; Cinulia obliqua, n.sp.; $C$. Mathewsoni, n.sp.; C. pinguis, n.sp.; Ringicula varia, n.sp.; Nerinea dispar, n.sp.; Acteonina? pupoides, n.sp.; A. Californica, n.sp.; Globi- 
concha (Phasianella?) Rémondi, n.sp.; Cylindrites brevis, n.sp.; Chemnitzia Spillmani, Conrad; Niso polita, n.sp.; Cerithiopsis alternata; Architectonica Veatchi, n.sp.; A. cognata, n.sp.; A. Horni, n.sp.; $A$. inornata, n.sp.; Margaritella crenulata, n.sp.; M. globosa, n.sp.; Discohelix leana, n.sp.; Straparollus paucivolus, n.sp.; S. lens, n.sp.; Angaria ornatissima, n.sp.; Conus Rémondi (Volutilithes Californica, Conrad); C. Horni, n.sp.; C. sinuatus, n.sp.; Rostellaria (sub.gen. Rimella); R. canalifera, n.sp.; R. (Rimella) simplex, n.sp.; Pugnellus hamulus, n.sp.; P. manubriatus, n.sp.; Tessarolax, n.gen.; T. distorta, n.sp.; Aporrhais falciformis, n.sp.; $A$. angulata, n.sp.; $A$. Californica, n.sp.; $A$. exilis, n.sp.; Cypræa? Bayerquei, n.sp.; Potamides diadema, n.sp.; $P$. tenuis, n.sp.; Littorina? compacta, n.sp.; Turritella infralineata, n.sp.; T. seriatim-granulata, Rœmer; T. Veatchi, n.sp.; T. Chicoensis, n.sp.; T. Uvasana, Conrad; T. Saffordi, Gabb; T. robusta, n.sp.; Galerus excentricus, n.sp.; Crypta (sub.gen. Spirocrypta); C. pileum, n.sp.; Nerita deformis, n.sp.; N. cuneata, n.sp.; Lysis, n.gen.; L.duplicosta, n.sp.; Dentalium (Ditrupa?) pusillum, n.sp.; D. Cooperi, n.sp.; D. stramineum, n.sp; Emarginula radiata, 11.sp.; Patella Traski, n.sp.; Helcion? circularis, n.sp.; H. dichotoma, n.sp.; Anisomyon Meeki, n.sp.; Actron impressus, n.sp.; Bulla Horni, n.sp.; Cylichna costata, n.sp.; Megistostoma, n.gen.; M. striata, n.sp. (Heilprin, Ter. Geol., p. 113, refers this to Bullia cf. Bullæa expansa, Dixson).

Conchifera-Martesia clausa, n.sp.; Turnus, n.gen.; T. plenus, n.sp.; Solen parallelus, n.sp.; Pharella alta, n.sp.; Siliqua Oregonensis, n.sp.; Panopæa concentrica, n.sp.; Corbula? primorsa, n.sp.; C. Traski, n.sp.; C. cultriformis, n.sp.; C. Horni, n.sp.; C. parilis, n.sp.; Anatina Tryoniana, n.sp.; A. inæquilateralis, n.sp.; A.? lata, n.sp.; Pholadomya Breweri, n.sp.; P. nasuta, n.sp.; Nerra dolabræformis, n.sp.; Mactra Ashburneri, n.sp.; Lutraria truncata, n.sp.; Asaphis undulata, n.sp.; Gari? texta, n.sp.; Tellina longa, n.sp.; T. Remondi, n.sp.; T. Hoffmanniana, n.sp.; T. monilifera, n.sp.; T. ooides, n.sp.; T. Mathewsoni, n.sp.; T. decurtata, n.sp.; T.? quadrata, n.sp.; T. Ashburneri, n.sp.; T. (? Sanguinolaria) Whitneyi, n.sp.; T. parilis, n.sp.; T. Horni, n.sp.; T. Californica, n.sp.; Venus (Mercenaria?) varians, n.sp.; V. Veatchi, n.sp.; $\boldsymbol{V}$. lenticularis, n.sp.; $V$. tetrahedra, n.sp.; Meretrix Uvasana, Conrad; M. lens, n.sp.; M. Horni, n.sp.; M. nitida, n.sp.; M. longa, n.sp.; Mr. arata, n.sp.; M. ovalis, n.sp.; M. Californica, Conrad; Dosinia elevata, Gabb (Heilprin, Ter. Geol,, p. 115, refers this to Disiniopsis Meeki, Conrad); D. pertenuis, n.sp.; D. gyrata, n.sp.; D. inflata, n.sp.; Tapes Conradiana, n.sp.; T.? quadrata, n.sp.; Trapezium carinatum, n.sp.; Cyprinella, n.gen.; C. tenuis, n.sp.; Cardium (Livicardium) annulatum, n.sp.; C. Rémondianum, n.sp.; C. Cooperi, n.sp.; C. Breweri, n.sp.; C. (Protocardium) Placerensis, n.sp.; Cardita Horni, n.sp.; Lucina nasuta, n.sp.; L. postradiata, n.sp.; $L$. subcircularis, n.sp.; L. cumulata, n.sp.; L.? cretacea, n.sp.; Loripes? dubia, n.sp.; Mysia? polita, n.sp.; Astarte Conradiana, n.sp.; $A$. Mathewsoni, n.sp.; A. Tuscana, n.sp.; Eriphyla, n.gen.; E. umbonata, n.sp.; Crassatella grandis, n.sp.; Anthonya, n.gen.; A. cultriformis, n.sp.; Unio penultimus, n.sp.; Mytilus pauperculus, n.sp.; M. ascia, n.sp.; Mr. humerus, Conrad; Modiola Siskiyouensis, n.sp.; M. ornata, n.sp.; M. cylindrica, n.sp.; Lithophagus oviformis, n.sp.; Septifer dichotomus, n.sp.; Crenella concentrica, n.sp.; Avicula pellucida, n.sp.; Inoceramus Piochi, n.sp.; Pinna Breweri, n.sp.; Trigonia Tryoniana, 
n.sp.; T. Evansi, Meek; T. Gibboniana, Lea?; Meekia, n.gen.; M. Sella, n.sp. (there is already a genus named Meekella, after Meek, so this will not stand); $M$. radiata, n.sp.; M. navis, n.sp.; Arca Breweriana, n.sp.; A. Horni, n.sp.; A. gravida, n.sp.; A. decurtata, n.sp.; Cucullæa Mathewsoni, n.sp.; C. truncata, n.sp.; Axinæa Veatchi, n.sp.; $A$. (Limopsis?) sagittata, n.sp.; A. cor, n.sp.; Nucula truncata, n.sp.; Leda protexta?, Gabb; L. translucida, n.sp.; Limopsis transversa, n.sp.; Pecten Traski, n.sp.; P. operculiformis, n.sp.; P. Californicus, n.sp.; Lima microtis, n.sp.; L. appressa, n.sp.; Plicatula variata,. n.sp.; Anomia lincata, n.sp.; Ostrea Breweri, n.sp.; O. malleiformis, n.sp.; Gryphæa vesicularis, Lam.; Exogyra parasitica, n.sp.; Terebratella obesa, n.sp.

ZoöPHYTA-Flabellum Rémondianum, n.sp.; Trochosmilia (subgen. Acrosmilia); T. striata, n.sp.; subgen. Ellipsosmilia? granulifera, n.sp.; Astroconia? petrosa, n.sp.

The Appendix contains descriptions of the following fossils :

Fusus mamillatus, n.sp.; Natica Uvasana, n.sp.; Scalaria Mathewsoni, n.sp.; Turritella infra-granulata, n.sp.; Solen Diegoensis, n.sp.; Chione? angulata, n.sp.; Tapes? cretacea, n.sp.; Crassatella Uvasana, Conrad; Cardita veneriformis, n.sp.; Barbatia Morsei, n.sp.; Yoldic nasuta, n.sp.; Placunanomia inornata, n.sp.

Palæontology, Vol. 2. Cretaceous and Tertiary fossils, by W. M. Gabb. Philadelphia, 1869. xiv and 299 pp., with 36 plates.

Section I. Tertiary invertebrate fossils:

Cancer Breweri, n.sp.; Triptera clavata, n.sp.; Trophon ponderosum, n.sp.; Neptunea recurva, n.sp.; Metula? Rémondi, n.sp.; Clavella gravida; n.sp.; C. sinuata, n.sp.; Pleurotoma (Surcula) Carpenteriana, Gabb; $P$. (S.) Tryoniana, n.sp.; $P$. (S.) perversa, Gabb; $P$. Voyi, n.sp.; Clathurella Conradiana, n.sp.; Ranella Mathewsoni, n.sp.; Cuma biplicata, n.sp.; Ancillaria Fishi, n.sp.; Columbella (subgen. Alia) Richthofeni, n.sp.; Neverita callosa, n.sp.; Cancellaria (subgen. Euclia) Tritonidea, n.sp.; C. (E.) vetusta, n.sp.; Bittium asperum, Gabb; Melania Taylori, n.sp.; Lithasia antiqua, n.sp; Littorina Rémondi, n.sp.; Turritella Hoffmanni, n.sp.; Trochita filosa, n.sp.; Pachypoma? biangulata, n.sp.; Turcica (subgen. Ptychostylis) coffea, Gabb; Calliostoma tricolor, Gabb; Zirphra dentata, n.sp.; Pandora scapha, n.sp.; Hemimactra lenticularis, n.sp.; Mulinia? densata, Conrad pars.; Schi zodesma abscissa, n.sp.; Pseudocardium, n.gen.; P. Gabbi, Rémond; Gari (subgen. Psammocola) alata, n.sp.; Venus Kennerlyi, Rve.? Mercenaria perlaminosa, Conrad; Chione Mathewsoni, n.sp.; $U$. Whitneyi, n.sp.; Callista Voyi, n.sp.; Dosinia Staleyi, n.sp.; D. Conradi, n.sp.; Tapes? truncata, n.sp.; Cyrena Californica, n.sp.; Cardium Meekianum, n.sp.; Conchocele, n.gen.; C. disjuncta, n.sp.; Lucina (subgen. Here); L. (H.) Richthofeni, n.sp.; Crassatella Collina, Conrad; Mytilus Mathewsoni, n.sp.; Modiola multiradiata, n.sp.; Arca sulcicosta,n.sp.; Yoldia Cooperi, Gabb ; Pecten Cerrosensis, n.sp.; P. Veatchi, n.sp.; Ostrea Bourgeoisi, Rémond; O.Atwoodi, n.sp.; O. Tayloriana, 
n.sp.; O. Veatchi, n.sp.; O. Cerrosensis, n.sp.; Terebratella Whitneyi, n.sp.; Morrisia Horni, Gabb.

Echinodermata-Clypeaster Gabbi, Rémond; Echinarachinus Brewerianus, Rémond; Scutella Gibbsi, Rémond; Astrodapsis Whitneyi, Rémond; A.tumidus, Rémond.

Asteriade-Asterias Rémondi, n.sp.

\section{Part 2.}

Muricidea (? Phyllonotus) paucivaricata, n.sp.; Trophon squamulifer, Cpr. (in lit.), n.sp.; Neptunea allispira, n.sp.; N. humerosa, n.sp.; Agasoma, n.gen.; A. gravida, Gabb; A. sinuata, Gabb; Surcula Tryoniana, Gabb : Nassa (sub.gen. Cxsia); Ficus pyriformis, n.sp.; F. nodiferus, n.sp.; Sinum planicostum, n.sp.; Cancellaria gracilior, Cpr. (in lit.), n.sp.; C. altispira, n.sp.; Trochita inornarta, n.sp.; Acmæa rudis, n.sp.; Zirphæa Gabbi, Tryon; Siliquaria? Edentula, n.sp.; Clidophora punctata, Conrad; Hemimactra? occidentalis, n.sp.; Pseudocardium (remarks on the genus); Venus pertenuis, Gabb; Caryatis Barbarensis, n.sp.; Meretrix Traski, Conrad; Dosinia Mathewsoni, n.sp.; Tapes Staleyi, Gabb; Saxidomus gibbosus, n.sp.; Yoldia nasuta, Gabb; $Y$. impressa, Conrad; Pecten Peckhami, n.sp.; P. Pedroanus, Trask; Ostrea Veatchi, Gabb; Tamiosoma gregaria, Conrad.

\section{Part 3 contains a synopsis of the Tertiary invertebrate} fossils of California.

Section II. Cretaceous fossils, Part 1, continued from Vol. 1.

Crustacea-Callianassa Stimpsoni, Gabb.

Mollusca-Ptiloteuthis, n.gen.; P. foliatuis, n.sp.; Belemnites impressus, Gabb; Ammonites Breweri, Gabb; A. Traski, Gabb; A. Hoffmanni, Gabb; A. Batesi, Trask; A. Tehamaensis, Gabb; A. Suciaensis, Meek; $A$. Jugalis, n.sp.; $A$. Whitneyi, n.sp.; $A$. Stoliczkanus, n.sp.; $A$. fraternus, n.sp.; Turrilites Oregonensis, Gabb; Ancyloceras Rémondi, Gabb; A. percostatus, Gabb; A.? lineatus, n.sp.; Helicancylus, n.gen.; H. æquicostatus, Gabb ; Diptychoceras, n.gen.; D. lævis, n.sp.; Baculites occidentalis, Meek.

GastrRopoda-Fusus tumiaus, n.sp.; F. occidentalis, n.sp.; Neptunea (Tritonofusus) cretacea, n.sp.; N. mucronata,n.sp.; Palæa tractus, n.gen.; $P$. crassus, n.sp.; Eripachya, n.gen.; E. ponderosa, Gabb; E. perforata, Gabb; E. Hoffmanni, Gabb; ? Neptunea gracilis, Gabb; Perissolax Blakei, Conrad; Surcula præattenuata n.sp.; S. (Surculites) sinuata, Gabb; S. (Surculites) inconspicus, n.sp.; Heteroterma, n.gen.; H. trochoidea, n.sp.; Bela clathrata, n.sp.; Cordiera mitræformis, n.sp.; Tritonium Californicum, n.sp.; T. (subgen. Trachytriton) Tejonensis, n.sp.; T. (T.) fusiformis, n.sp.; Brachysphingus, n.gen.; B. liratus, Gabb; Bulla (Molopophorus) striata, n.sp.; Turbinella crassitesta, n.sp.; Mitra cretacea, Gabb; Ficopsis Remondi, Gabb; F. Horni, Gabb; F. Cooperi, Gabb ; Urosyca, n.gen.; U.caudata, n.sp.; Sycodes, n.gen.; S. cypræoides, Gabb; Euspira alveata, Conrad; Neverita globosa, n.sp.; Ampullina striata, n.sp.; Terebra Californica, n.sp.; Chemnitzia planulata, Gabb; Pugnellus hamulus, Gabb; P. (Gymnarus) manubriatus, Gabb; Cypræa (Luponia) Bayerquei, Gabb; C. (Epona) Mathewsonia, n.sp.; Anchura 
falciformis, Gabb; A.transversa, n.sp.; 2 A. carinifera,n.sp.; Helicaulax bicarinata, n.sp.; H. costata, n.sp.; Loxotrema turrita, n.sp.; Atresius, n.gen.; A.liratus, n.sp.; Turritella Martinezensis, n.sp.; Nerita (Theliostyla) triangulata, n.sp.; Calliostoma radiatum, n.sp.; Ataphrus, n.gen.; A.crassus, n.sp.; Margaritella angulata, n.sp.; Acmæa Tejonensis, n.sp.; Actronina pupoides, Gabb; Actronella oviformis, n.sp.; Liocium, n.gen.; L. punctatum, n.sp.; Ringinella polita, n.sp.; $R$. pinguis, Gabb.

Acephala - Martesia clausa, Gabb; Solen (Hypogella) cuneatus, n.sp.; S. (H.) Diegoensis, Gäbb; Corbula Horni, Gabb ; C. alæformis, n.sp.; Anatina quadrata, n.sp.; Pholadomya Oregonensis, n.sp.; Pleuromya papyracea, n.sp.; Arcomya undulata, n.sp.; Homomya concentrica, Gabb; Mactra? tenuissima, n.sp.; Cymbophora, n.gen.; C. Ashburneri, Gabb; Asaphis multicostata, n.sp.; Tellina Rémondi, Gabb; T. Hoffmanni, Gabb; T. æqualis, n.sp.; T. undulifera, n.sp.; Donax latus, n.sp.; Venus æquilateralis, n.sp.; Meretrix? fragilis, n.sp.; M. Horni, Gabb; Caryatis nitida, Gabb; Thetis? elongata, n.sp.; Cardium (Lrvicardium) annulatum, Gabb; C. (Protocardium) translucidum, n.sp.; Cardita Horni, Gabb ; Clisocolus, n.gen.; C. dubius, Gabb ; Lucina nasuta and L. postice-radiata; Crassatella grandis, Gabb; C. compacta, n.sp.; Unio Hubbardi, n.sp.; Mytilus quadratus, n.sp.; Modiola major, n.sp.; Meleagrina antiqua, n.sp.; Inoceramus Elliotti, n.sp.; I. Whitneyi, n.sp.; Aucella Piochi, Gabb; Pinna Breweri, Gabb; Trigonia æquicostata, n.sp.; Axinæa sagittata, Gabb; Nucula (Acila) truncata, Gabb; N. solitaria, n.sp.; Leda Gabbi, Conrad; Pecten Traski, Gabb; P. Martinezensis, n.sp.; P. complexicosta,n.sp; P. interradiatus, n.sp.; Neithea grandicosta, n.sp.; Lima Shastaensis, n.sp.; $L$. multiradiata, n.sp.; Anomia Vancouverensis, n.sp.; Ostrea Idriaensis, n.sp.; 0 . appressa n.sp.; (O. Idriaensis (Gabb), White, 4th Ann. Rep. U. S. Geol. Sur., p. 291.)

BrachIOPODA-Rynchonella Whitneyi, Gabb.

RADIATA-Smilotrochus? curtus, n.sp.

Part 2 contains a synopsis of the Cretaceous invertebrate fossils of California.

Section III contains description of the Cretaceous fossils from Mexico; by W. M. Gabb.

Geology, Vol. 1. Report of progress and synopsis of the fieldwork from 1860 to 1864 . Philadelphia, 1865. xxxii and 498 pp., and plate.

Part 1 of this report contains: Geology of the Coast Range, Contra Costa hills, Monte Diablo group, Mount Hamilton group, Monte Diablo group, south of Pacheco's Pass; the Peninsula of San Francisco; the coast ranges north of the Bay of San Francisco; the coast ranges south of the Bay of Monterey; the coast ranges from the vicinity of Los Angeles south; the region between the Canada de las Uvas and Soledad Pass.

Part 2. The geology of the Sierra Nevada; the undisturbed marine sedimentary rocks along the foothills of the Sicrra; the mining regions of California, embracing the great auriferous belt along the 
western slope of the Sierra Nevada; the high Sierra region about the head of Kern, Kings, San Joaquin, Merced, Tuolumne, and Mokelumne rivers; the eastern slope-Mono Lake and its vicinity, Owen's Valley, the Great Basin, etc.

Appendix A. Tabular statement of the operations of the principal quartz mills; by W. Ashburner.

Appendix B. Description of fossils from the auriferious slates of California ; by F. B. Neek.

The following fossils are described and illustrated in this report: Amussium aurarium, Meek ; Aucella Erringtoni, Gabb ; A. Erringtoni var. lingulifromis; Pholadomya? orbiculata, Gabb; and Belemnites Pacificus, Gabb.

Contributions to barometric hypsometry, with tables for use in California. Cambridge, 1874.88 pp. (Supplementary chapter added in 1878 ; pp. 89-112.)

Supplementary chapter, and practical application of the tables to the observations of the year 1870-71, and a. discussion of the results obtained; by J. D. Whitney. Cambridge, 1878. 24 pp.

Botany, Vol. 1.' Polypetalæ, by W. H. Brewer and Sereno Watson. Gamopetalæ, by Asa Gray. Cambridge, 1876. $\mathrm{xx}$ and $628 \mathrm{pp}$.

Ornithology, Vol. 1. Land-birds; edited by S. F. Baird from the manuscript and notes of J. G. Cooper. Cambridge, 1870. xi and $592 \mathrm{pp}$.

Map of region adjácent to the Bay of San Francisco. 2 miles to 1 inch. New York, 1873.

Map of California and Nevada. 1873. State Geological Survey of California; J. D. Whitney, State Geologist. Drawn by F. von Leicht and A. Craven. Scale, 18 miles to 1 inch.

Same, $2 \mathrm{~d}$ edition. Revised by Hoffmann \& Crane, and issued by authority of the Regents of the University of California, May 12, 1874. Same scale.

Same, 3 d edition. Published by W. D. Walkup \& Co. San Francisco, 1878. Same scale.

A new edition by W. D. Walkup \& Co. 1887.

The following volumes and memoirs are to be credited to the Geological Survey of California, J. D. Whitney, Director, as a 
continuation, in part, of the work stopped by the Legislature in 1874; permission having been given to the late State Geologist, by the Board of Regentș of the University of California, in whose hands the matter was left, to continue the publications:

Geology, Vol. 2. The Coast Ranges. Appendix. Cambridge, 1882. $148 \mathrm{pp} .5$ plates. (Uniform with publications of the Geological Survey of California, J. D. Whitney, State Geologist.)

This report contains-

A. Detailed description of the Monte Diablo coal fields; by W. A. Goodyear. April, 1870.

B. Additional notes on the Monte Diablo coal mines; by W. A. Goodyear. June, 1873.

C. Statistics of the Monte Diablo coal mines; by W. A. Goodyear. January, 1874.

D. Notes descriptive of the condition of the Corral Hollow coal mines; by W. A. Goodyear. August, 1870.

E. Chemical examination of the Pacific coals; by S. F. Peckham. I, July, 1872; II, September, 1872.

F. Examination of the Bituminous Substances in Southern California ; by S. F. Peckham. Part I, Geological and Historical (June, 1866). Part II, Chemical Investigations: Section 1, February, 1867; Section 2, January, 1871.

G. Report on an examination of the Quicksilver Mines of California; by W. A. Goodyear. May, 1871.

H. Notes on the Geology of Lower California; by W. M. Gabb.

Botany, Vol. 2; by Sereno Watson. Cambridge, 1880. xv and $559 \mathrm{pp}$.

The water-birds of North America; by S. F. Baird, T. M. Brewer, and R. Ridgeway. Issued in continuation of the publications of the Geological Survey of California. Boston, 1884. Vol. 1, xi and 537 pp.; Vol. 2, 552 pp.

Report on the fossil plants of the auriferous gravel deposits of the Sierra Nevada; by Leo Lesquereux. Cambridge, 1878. viii and $62 \mathrm{pp}$., with 10 double plates.

Memoirs of the Museum of Comparative Zoölogy. Vol. VI, No. 2.

This report contains descriptions of the following fossil plants: Acer æquidentatum, n.sp.; A. Bolanderi, n.sp.; Aralia angustiloba, n.sp.; A. Whitneyi, n.sp.; A. Zaddachi? Heer; Betula æqualis, n.sp.; Cercocarpus antiquus, n.sp.; Castaneopsis chrysophylloides, n.sp.; Cornus Kelloggi, n.sp.; C. ovalis, n.sp.; Fagus antipofi, n.sp.; F. pseudo-ferruginea, 
n.sp.; Ficus microphylla, n.sp.; F. sordida, n.sp.; F. tilixfolia, Al. Br.; Ilex prunifolia, n.sp.; Juglans Californica, n.sp.; J. Oregoniana, n.sp.; $J$. laurinea, n.sp.;-Liquidambar Californicum,n.sp.; Magnolia Californica, n.sp.; M. lanceolata, n.sp.; Platanus appendiculata, n.sp.; P. dissecta, n.sp.; Populus Zaddachi, Heer; Persea pseudo-carolinensis, n.sp. Quercus Boweniana, n.sp.; Q. chrysophylloides, n.sp.; Q. convexa, n.sp., Q. distincta, n.sp.; Q. elinoides, n.sp.; Q. Goepperti, n.sp.; Q. Nevadensis, n.sp.; Q. pseudo-lyrata, n.sp.; Q. Voyana, n.sp.; Rhus Boweniana, n.sp.; $R$. dispersa, n.sp.; R. metopioides, n.sp.; $R$. mixta, n.sp.; $R$. myricxfolia, n.sp.; R. typhinoides, n.sp.; Sabalites Californicus, n.sp.; Salix Californica, n.sp.; S. elliptica, n.sp.; Ulmus affinis, n.sp.; U. Californica, n.sp.; U. pseudo-fulva, n.sp.; Zanthoxylon diversifolium, n.sp.; Zizyphus microphyllus, n.sp.; Z. piperoides, n.sp.

The auriferous gravels of the Sierra Nevada of California; by J. D. Whitney. Cambridge, 1879-80, pp. 1-288; pp. 289-569, 1880. 24 plates and 2 geological maps.

The climatic changes of later geological times. A discussion based on observations made-in the Cordilleras of North America. By J. D. Whitney. Cambridge, 1880-82. $394 \mathrm{pp}$.

\title{
CALIFORNIA STATE MINING BUREAU.
}

\author{
HENRY G. HANKS, State Mineralogist.
}

Annual Report of the State Mineralogist, from June 1, 1880, to December 1, 1880. Sacramento, 1880. $43 \mathrm{pp}$.

This report contains analysis of clay from a deposit at Lincoln, Placer County.

Second Report of the State Mineralogist, from December 1, 1880 , to October 1, 1882. Sacramento, 1882. $288 \mathrm{pp}$., map and 4 photographs, with appendix. (The index to this report was published separately.)

The report contains articles on placer, hydraulic, and drift mining; general geology; iron ores and iron industries of California; lumber and fuel; the occurrence of salt in California, and its manufacture ; mud volcanoes; the Colorado Desert; diamonds in California ; notes on mica; diatoms and diatomaceous earths; contribution to ethnology and geology of the Pacific Slope, by Philip Harvey.

The appendix contains the following papers: 1 . Forest trees of California, by A. Kellogg; 2. Notes on hydraulic mining, by F. W. Robinson; 3. Hydraulic and drift mining, by H. Degroot; 4. On the milling of gold quartz, by M. Attwood; 5. Rare minerals recently found in the State, by William P. Blake. 
Contributions to the Geology and Mineralogy of California; by IVilliam P. Blake. Sacramento, 1881. $15 \mathrm{pp}$.

This report contains a description of new mineral localities.

No. 2. Section from Merced to Coulterville and Big Oak Flat.

No. 3. Coulterville to (Minese Camp.

No. 4. Chinese Camp to Sonora.

No. 5. Occurrence of vanadates of lead at the Castle Dome mines.

Contributions to the Geology and Mineralogy of California: On the milling of gold quartz; by Melville Attwood. Sacramento, 1882. $20 \mathrm{pp}$.

First Annual Catalogue of the State Museum of California, being the collection made by the State Nining Bureau during the year ending April 16, 1881. Sacramento, 1882. 350 pages.

Third Annual Report of the State Mineralogist, for the year ending June, 1883. Sacramento, 1883. 111 pp. and 1 map.

Part 2 contains a report on the borax deposits of California and Nevada, by Henry G. Hanks.

Fourth Annual Report of the State Mineralogist, for the year ending May 15, 1884. Sacramento, 1884. 410 pp. and 2 plates.

This volume contains a general account of the agricultural, commercial, manufacturing, and other resources, interests, and industries of California, by Henry Degroot.

Also, a catalogue and description of the minerals of California as far as known, with special reference to those having an economic value. Alphabetically arranged.

Fifth Annual Report of the State Mineralogist, for the year ending May $15, \cdot 1885$. Sacramento, 1885. 235 pp., 1 plate and 4 sections.

Sixth Annual Report of the State Mineralogist, for the year ending June 1, 1886. Part I. Sacramento, 1886. 145 pp. and 1 map.

This report contains an article on building-stones and buildingmaterials in California ; table of altitudes; record of strata in artesian well, Kern County; mineral springs in California; Calistoga silver mines; a general account of San Diego County, with map of Julian District. The report closes with a list of California minerals. 
Catalogue of books, maps, lithographs, photographs, etc., in the library of the State Mining Bureau at San Francisco, May 15, 1884. Sacramento, 1884. $19 \mathrm{pp}$.

Catalogue of the State Museum of California, Vol. 2, being the collection made by the State Mining Bureau from April 16, 1881, to May 15, 1884. Sacramento, 1885. 220 pp.

\section{WILLIAM IRELAN, JR, State Mineralogist.}

Sixth Annual Report of the State Mineralogist, for the year ending June 1, 1886. Part II. Sacramento, 1887. 222 pp. Illustrated.

Contains reports on the mines of Amador, Butte, Calaveras, El Dorado, Fresno, Nevada, Sierra, and Tuolumne Counties.

Catalogue of the State Museum of California, Vol. 3, being the collection made by the State Mining Bureau from May 15, 1884, to March 31, 1887. Sacramento, 1887. 195 pp.

Seventh Annual Report of the State Mineralogist, for the year ending October 1, 1887. Sacramento, 1888. $315 \mathrm{pp}$.

This report contains an article on petroleum, asphaltum, and natural gas of California, by W. A. Goodyear; also, a report on coal, with reports on natural gas and coal in California, by A.H. Weber; petroleum and asphaltum in portions of Northern California, by A. H. Weber; building-stones of California, by Prof. A. Wendell Jackson; production of precious metals, report of Wells, Fargo \& Co.; with a catalogue of fossils, by J. G. Cooper.

Eighth Annual Report of the State Mineralogist, for the year ending October 1, 1888. Sacramento, 1888. $948 \mathrm{pp}$. Illustrated.

This report contains the mineral resources of the State, considered by counties, with reports on natural and artificial cement, buildingstones, etc.; reports on Inyo, Kern, Los Angeles, San Bernardino, San Diego, and Tulare Counties, by W: A. Goodyear; Mono County, by H. A. Whiting; Ventura County, by S. Bowers; drift mining in California, by R. L. Dunn; lithology of wall rocks, by M. Attwood.

Bulletin No. 1. A description of the desiccated human remains in the California State Mining Bureau; by Winslow Anderson, M.D. Sacramento, 1888. 41 pp. and 6 plates. 
Ninth Annual Report of the State Mineralogist, for the year ending December 1, 1889. Sacramento, 1890. $352 \mathrm{pp}$. and 34 plates.

This report contains an article on Santa Clara County, by A. H. Weber; the geology of San Nicolas Island, by Dr. Stephen Bowers; the auriferous gravels of California, geology of their occurrence and methods of their exploitation, by John Hays Hammond; San Diego County, by W. A. Goodyear; Santa Cruz Island, by W. A. Goodyear; stray notes on the geology of the channel islands, by Dr. L. G. Yates; the mollusca of the channel islands of California, by Dr. L. G. Yates; with reports on Los Angeles County, by E. B. Preston, and San Bernardino County, by James H. Crossman; the value of fossils as indications of important mineral products, by Dr. J. G. Cooper; with report on clays, by W. D. Johnston; etc.

Tenth Annual Report of the State Mineralogist, for the year ending December 1, 1890. Sacramento, 1890. $981 \mathrm{pp}$. Maps and plates.

This report contains a geological map of the State, with the following special reports relating to geology, viz.:

Geology of the Mother Lode region; by $\mathrm{H}$. W. Fairbanks.

Geological features of Placer County. pp. 414-418.

Geology of Nevada County. p. 368.

Geology of the Colorado Desert. pp. 907-919.

Geology of Trinity County. p. 695.

Geology of Orange County. pp. 399-409.

Fossils of the Carboniferous period. p. 917.

Fossils of Orange County. pp. 407-408.

List of Cretaceous fossils in Santa Ana Mountains, Orange County. p. 400.

Fossils of Ventura County. p. 762.

With other reports containing geological information.

Catalogue of the State Museum of California, Vol. 4, being the collection made by the State Mining Bureau from March 31, 1887, to August 20, 1890. Sacramento, 1890. $261 \mathrm{pp.}$

Catalogue of the Library of the California State Mining Bureau, San Francisco, September 1, 1892. Sacramento, 1892. $149 \mathrm{pp}$.

Eleventh Report (First Biennial) of the State Mineralogist, for the two years ending September 15, 1892. Sacramento, 1893. $612 \mathrm{pp}$.

This report contains the following special articles on geology, viz.:

Geology and mineralogy of Shasta County; by H. W. Fairbanks. pp. 24-53. 
Notes on the geology and mineralogy of portions of Tehama, Colusa, Lake, and Napa Counties; by H. W. Fairbanks. pp. 54-75.

Geology of San Diego County, also of portions of Orange and San Bernardino Counties; by H. W. Fairbanks. pp. 76-120.

Geology of Calico District, San Bernardino County. pp. 337, 338, $339,340,343$.

Geology of the Lava Bed District, San Bernardino County. pp. 349 and 350.

Geology in the region of Mineral Spring, Siskiyou County. pp. 451,452 ; etc., etc.

\section{J. J. CRAWFORD, State Mineralogist.}

Twelfth Report (Second Biennial) of the State Mineralogist, for the two years ending September 15, 1894. Sacramento, 1894. $541 \mathrm{pp}$. Maps and illustrations.

This report contains an article on-

The auriferous conglomerate in California; by R. L. Dunn.

Preliminary report on the mineral deposits of Inyo, Mono, and Alpine Counties; by H. W. Fairbanks.

Ancient channel system of Calaveras County; by W. H. Storms.

Geology of northern Ventura, Santa Barbara, San Luis Obispo, Monterey, and San Benito Counties; by H. W. Fairbanks.

Bulletin No. 2. San Francisco, June, 1894. Methods of minetimbering; by W. H. Storms. Sacramento, 1894. 58 pp., with illustrations. (A second edition was issued in 1896.)

Bulletin No. 3. San Francisco, August, 1894. The gas and petroleum yielding formations of the Central Valley of California; by W. L. Watts. Sacramento, 1894. 100 pp. Maps and illustrations.

Bulletin No. 4. San Francisco, September, 1894. Catalogue of California fossils, Parts II, III, IV, and V; by Dr. J. G. Cooper. Sacramento, 1894. 6 plates. (Part I was published in the Seventh Annual Report of the State Mineralogist for 1887.)

The following new species are described and figured:

Cretaceous and Eocene Fossils-Teretra Wattsiana, Surcula crenatospira, S. monilifera, S. inconstans, Pleurotoma Perkinsiana, P. decipiens, Drillia ullreyana, Mangilia suturalis, Cordiera gracillima, Cancellaria Irelaniana, Ancilla (Oliverato) Californica, Bittium longissimum, Cerithium Fairbanksi, Potamides carbonicola, P.Davisiana, Fusus supraplanus, Mitra simplicissima, Stomatia intermedia, Calliostoma Kempiana, Tornatella normalis, Bulla assimilata, Tornatina erratica, Siphonaria capuloides, Astarto semidentata, Crassatella lomana, Cucul- 
læa Bowersiana, Corbula triangulata, Mytilus dichotomus, Crenella Santana, Megerlia dubitanda, Waldheimia imbricata.

Thrtiary-MIocene and Plioche-Agasoma Barkerianum, Trophosycon (n.subgen.), Agasoma? (Trophosycon) Kernianum.

Fresir-Water Fossins-Limnea Contracosta; Planorbis Pabloanus; Anodonta (Nuttalliana) lignitica; Amnicola Yatesiana; Pinna. Alamedensis, Yates; P. Venturensis, Yates; Pecten discus, Conrad; Liropecten estrellanus, Conrad.

Bulletin No. 5. San Francisco, October, 1894. The cyanide process, its practical application and economical results; by Dr. A. Scheidel. Sacramento, 1894. 140 pp.

Catalogue of West North American and many foreign shells, with their geographical ranges. For labels, exchange, and check-lists, with a supplement. By J. G. Cooper. Printed for the State Mining Bureau, April, 1894. Sacramento, 1894.

Bulletin No. 6. California gold mill practices; by Ed. B. Preston. Sacramento, 1895. $85 \mathrm{pp}$.

Bulletin No. 7. Showing, by counties, the mineral productions of California for the year 1894; by Charles G. Yale. Sacramento, 1895. Tabular sheet.

Bulletin No. 8. Showing, by counties, the mineral productions of California for the year 1895; by Charles G. Yale. Sacramento, 1896. Tabular sheet.

Bulletin No. 9. Mine drainage, pumps, etc.; by Hans C. Behr. Sacramento, 1896. 200 pp. 206 illustrations.

\section{CALIFORNIA SENATE AND ASSEMBLI DOCUMEN'TS.}

California Senate and Assembly Journal, 15th Session.

Trąnsactions California State Agricultural Society during the year 1863. Gives a list of gold mines. pp. 101-118.

Mining Review for 1863 . Contains an article on placer gold mining ; also a notice of silver mining, of quartz gold and silver mining, and of copper, coal, iron, petroleum and asphaltum, quicksilver mines, etc. pp. 176-193. 
California Senate and Assembly Journal, 16th Session, 1866. Vol. 3, pp. 314-356.

Gives an account of California marble, p. 314.

Mining leview for 1865. Gives the extent of the mining field, variety of ore, mineral products, placer and surface diggings, quartz mining, silver mines, coal, quicksilver, petroleum, etc. pp. 315-334.

Annotated catalogue of the principal mineral species bitherto recognized in California and adjoining States and Territories; by W. P. Blake. March, 1866 . pp. 335-356.

Notes on the geographical distribution and geology of the precious metals and valuable minerals of the Pacific Slope. pp. 359-364. [Prof. W. P. Blake was appointed the Geologist of the State Board of Agriculture in 1866, and made a report on the minerals of California under the above title. The report was also published in pamphlet form, with the same title. Reviewed Amer. Jour. Sci., Vol. 42, 1866, pp. 114-118.]

The same volume also contains a Report of Assembly Committee on Mines and Mining Interests, concerning the State Geological Survey; also, the Report of the State Geologist for 1863-64.

California Senate and Assembly Journal, 17th Session. No. 3. Gold, silver, platinum, and rare metals. Sacramento. 1867.

\section{CALIFORNIA STATE UNIVERSITY.}

Report on Mount Diablo coals; by S. B. Christy. In reports to the President of the University, from the Colleges of Agriculture and the Mechanic Arts, pp. 70-74. Sacramento, 1877.

Report on the genesis of cinnabar deposits; by S. B. Christy. Berkeley, 1878.

Report of Professor J. D. Whitney to the honorable the Board of Regents of the University of California. In Biennial Report of the Regents of the University of California for the years 1877-79, pp. 82-85. Sacramento, 1879.

List of recorded earthquakes in California, Lower California, Oregon, and Washington Territory. Compiled from published works and from private information, by Edward S. Holden. Printed by direction of the Regents of the University of California. Sacramento, 1887. $78 \mathrm{pp}$. 
Bulletin of the building-stones of California; by A. Wendell Jackson. California University, Berkeley, 1888. Supplement to Secretary's report.

This paper gives notes and microscopic examinations of .Santa Susanna sandstones, Henly sandstones, Campo Seco tufa, Colton marbles, etc.

List of printed maps of California; by J.C. Rowell. Univ. of Cal., Library Bull. No. 9. Berkeley, 1887.

The geology of Carmelo Bay, by Andrew C. Lawson; with chemical analysis and coöperation in the field, by Juan de la C. Posada. Univ. of Cal., Bull. Dept. of Geology, Vol. 1, pp. 1-59, pls. 1-4. Berkeley, 1893.

This report contains a general statement of the geology of the district survey, with special chapters on the granites and eruptive rocks.

The soda-rhyolite north of Berkeley; by Charles Palache. Univ. of Cal., Bull. Dept. of Geology, Vol. 1, No. 2, pp. 61-72, pl. 5. Berkeley, 1893.

The eruptive rocks of Point Bonita; by F. Leslie Ransome. Univ. of Cal., Bull. Dept. of Geology, Vol. 1, No. 3, pp. 71-114, pls. 6-7. Berkeley, 1893.

The Post Pliocene diastrophism of the coast of Southern California; by Andrew C. Lawson. Univ. of Cal., Bull. Dept. of Geology, Vol. 1, No. 4, pp. 115-160, pls. 8-9. Berkeley, 1893.

The lherzolite-serpentine and associated rocks of the Potrero, San Francisco. On a rock from the vicinity of Berkeley, containing a new soda Amphibole; by Charles Palache. Univ. of Cal., Bull. Dept. of Geology, Vol. 1, Nos. 5-6, pp. 161-192, pls. 10-11. Berkeley, 1894.

The geology of Angel Island, by F. Leslie Ransome; with a note on the Radiolarian chert from Angel Island and from Buri-buri Ridge, San Mateo County, California. Univ. of Cal., Bull. Dept. of Geology, Vol. 1, No. 7, pp. 193-240, pls. 12-14. Berkeley, 1894.

The Radiolaria (suborder Sphreroidea) described in this report are of the genera Cenosphxra, Carposphara, Cenellipsis, Ellipsidium, Lithapium; suborder Discoidea, genera Tripocyclia, Hagiastrum; suborder Cyrtoidea, genera Dictyomitra, Lithocampe, and Sethocapsa. 
The geomorphogeny on the coast of Northern California; by Andrew C. Lawson. Univ. of Cal., Bull. Dept. of Geology, Vol. 1, No. 8, pp. 241-272. Berkeley, 1894.

On analcite diabase from San Luis Obispo County, California; by Harold W. Fairbanks. Univ. of Cal., Bull. of Geology, Vol.1, No. 9, pp. 273-300, pls. 15-16. Berkeley, 1895 .

On Lawsonite, a new rock-forming mineral from the Tiburon Peninsula, Marin County, California; by F. Leslie Ransome. Univ. of Cal., Bull. Dept. of Geology, Vol. 1, No. 10, pp. 301-312, pl. 17. Berkeley, 1895.

Critical periods in the history of the earth; by Joseph Le Conte. Univ. of Cal., Bull. Dept. of Geology, Vol. 1, No. 11, pp. 313-336. Berkeley, 1895.

A list of type specimens in the Geological Museum of the University of California, which have served as originals for figures and descriptions in the palæontology of the State Geological Survey of California under J. D. Whitney. Compiled for the use of workers in California geology, by John C. Merriam. Univ. of Cal., Bull. Dept. of Geology. Berkeley, 1895. 3 pp.

In a few cases the supposed type differed slightly, but unessentially, from the figure. Names of such species are followed in the list by an interrogation point.

\section{CRETACEOUS.}

Callianassa Stimpsoni, Gabb; Vol. I, pl. 9, fig. $1 a, 1 b$.

Amm. (Haploceras) Breweri, Gabb; Vol. I, pl. 10, fig. 7.

Amm. Cooperi, Gabb; Vol. I, pl. 14, fig. 23, $23 a$.

Amm. Haydeni, Gabb; Vol. I, pl. 10, fig. 8.

Amm. jugalis, Gabb; Vol. I, pl. 10, fig. 5 .

Amm. Peruvianus, Von Buch; Vol. I, pl. 10, fig. 9.

Amm. (Hoplites) Rémondi, Gabb; Vol. I, pl. 12, fig. 14.

Amm. (Phylloceras) ramosus, Gabb ; Vol. I, pl. 11, fig. 12, pl. 12, fig. $12 b$.

Amm. suciaensis, Meek; Vol. I, pl. 21, fig. 11.

Amm. Tehamaensis, Gabb; Vol. I, pl. 10, fig. 4.

Baculites Chicoensis, Trask; Vol. I, pl. 14, fig. 29.

Belemintes impressus, Gabb; Vol. I, pl. 9, fig. 2.

Crioceras latus, Gabb; Vol. I, pl. 15, fig. 25.

Helicancyclus æquicostatus, Gabb; Vol. I, pl. 13, fig. 20.

Helicoceras declive, Gabb; Vol. I, pl. 28, fig. 200, $200 a$.

Helioceras Breweri, Gabb (?); Vol. I, pl. 14, fig. 22. 
Actronina Californica, Gabb; Vol. I, pl. 19, fig. 68 (fragments). Actronina pupoides, Gabb; Vol. I, pl. 19, fig. 67.

Chemintzia planulata, Gabb; Vol. I, pl. 19, fig. 70.

Cylindrites brevis, Gabb; Vol. I, pl. 29, fig. 223.

Eripachya Hoffmanni, Gabb; Vol. I, pl. 18, fig. 41.

Fusis Averilli, Gabb; Vol. I, pl. 18, fig. 34 .

Fusus Kingi, Gabb; Vol. I, pl. 28, fig. 204.

Globiochonca Rémondi, Gabb; Vol. I, pl. 19, fig. 69.

Lunatia Conradiana, Gabb; Vol. I, pl. 29, fig. 219.

Lysis duplicostata, Gabb; Vol. I, pl. 21, fig. 98.

Pugnellus manubriatus, Gabb (?); Vol. I, pl. 29, fig. 229, $229 a$.

Ringinella pinguis, Gabb; Vol. I, pl. 29, fig. $221 a$.

Tessarolax distorta, Gabb (?); Vol. I, pl. 20, fig. 82, $82 b$.

Turritella Chicoensis, Gabb; Vol. I, pl. 21, fig. 91.

Turritella seriatim-granulata, Gabb; Vol. I, pl. 20, fig. 88.

Turritella Veatchi, Gabb (?); Vol. I, pl. 20, fig. 90.

Anatina lata, Gabb; Vol. I, pl. 22, fig. 126.

Anomia lineata, Gabb; Vol. I, pl. 26, fig. 193.

Arca decurtata, Gabb; Vol. I, pl. 31, fig. 265, $265 a$.

Arca gravida, Gabb; Vol. I, pl. 30, fig. 264.

Astarte tuscana, Gabb; Vol. I, pl. 30, fig. 257.

Aucella Piochi, Gabb; Vol. I, pl. 25, fig. 173, 174.

Corbula cultriformis, Gabb; Vol. I, pl. 22, fig. 122.

Cyprinella (Diodus) tenuis, Gabb; Vol. I, pl. 23, fig. 15la.

Dosinia inflata, Gabb; Vol. I, pl. 23, fig, 149.

Homomya (Panopea) concentrica, Gabb; Vol. I, pl. 22, fig. 119.

Lithophagus oviformis, Gabb; Vol. I, pl. 25, fig. 168.

Martesia clausa, Gabb; Vol. I, pl. 22, fig. 115.

Meekia navis, Gabb; Vol. I, pl:25, fig. 180.

Meekia radiata, Gabb; Vol. I, pl. 25, fig. 179a.

Meretrix longa, Gabb; Vol. I, pl. 23, fig. 147.

Meretrix ovalis, Gabb; Vol. I, pl. 30, fig. 251.

Modiola cylindrica, Gabb; Vol. I, pl. 25, fig. 167.

Mytilus pauperculus, Gabb; Vol. I, pl. 25, fig. 165.

Ostrea Breweri, Gabb; Vol. I, pl. 26, fig. 191.

Pholadomya Breweri, Gabb; Vol. I,.pl. 22, fig. 123.

Pholadomya nasuta, Gabb; Vol. I, pl. 30, fig. 124.

Pinna Breweri, Gabb; Vol. I, pl. 25, fig. 175.

Tellina decurta, Gabb; Vol. I, pl. 23, fig. 137.

Tellina monilifera, Gabb (?); Vol. I, pl. 22, fig. 134, $134 a$.

Tellina ooides, Gabb; Vol. I, pl. 22, fig. 135, 135a.

Terebratella obesa, Gabb (?); Vol. I, pl. 26, fig. 194.

Trigonia Gibboniana, Gabb; Vol. I, pl. 25, fig. 178.

Trigonia Tryoniana, Gabb; Vol. I, pl. 25, fig. 176.

Venus (Chione) varians, Gabb; Vol. 1, pl. 23, fig. 140.

Flabellum Rémondianum, Gabb; Vol. I, pl.26, fig. 199.

Astrocxnia (?) petrosa, Gabb (?); Vol. I, pl. 31, fig. 274, 274a.

\section{EOCENE (TEJON).}

Fusus martinez, Gabb; Vol. I, pl. 18, fig. 32.

Margaritella crenulata, Gabb; Vol. I, pl. 20, fig. 74.

Neptunea supraplicata, Gabb; Vol. I, pl. 18, fig. 40. 
Neptunea gracilis, Gabb; Vol. I, pl. 18, fig. 42.

Trachytriton (Tritonium) Diegoensis, Gabb; Vol. I, pl. 18, tig. 44.

Crypta (spirocrypta) pileum, Gabb (?); Vol. I, pl. 29, fig. 233, 2436.

Arca Horni, Gabb; Vol. I, pl. 30, fig. 263.

Avicula pellucida, Gabb ; Vol. I, pl. 25, fig. 172.

Barbatia Morsei, Gabb (?); Vol. I, pl. 32, fig. 286.

Dosinia gyrata, Gabb ; Vol. I, pl. 23, fig. 148.

Lucina cumulata, Gabb; Vol. I, pl. 24, fig. 254.

Mysia polita. Gabb; Vol. I, pl. 30, fig. 256.

Mytilus ascia, Gabb; Vol. I, pl. 30, fig. 259.

Nexra dolabræformis, Gabb (?); Vol. I, pl. 22, fig. 125.

Pectunculus (Axnira) cor, Gabb; Vol. I, pl. 31, fig. 268, $268 a$.

Stalagmium (Crenella) concentricum, Gabb; Vol. I, pl. 24, fig. 169.

Unio penultimus, Gabb (?); Vol. I, pl.24, tig. 164.

\section{MIOCENE.}

Cancer Breweri, Gabb; Vol. II, pl. 1, fig. 1.

Scutella Gibbsi, Gabb; Vol. II, pl. 13, fig. 66.

Echinarachinus Brewerianus, Gabb; Vol. II, pl. 12, fig. 64.

Ancillaria Fishi, Gabb (?); Vol. II, pl. 2, fig. 15.

Indet ; Vol. II, pl. 3, fig. 29.

Indet; Vol. II, pl. 3, fig. 30.

Triptera clavata, Gabb; Vol. II, pl. 1, fig. 2.

Trochita inornata, Gabb (?); Vol. II, pl. 14, fig. 8.

Conchocele disjuncta, Gabb; Vol. II, pl. 7, fig. 48.

Modiola multiradiata, Gabb (?); Vol. II, pl. 8, fig. 52.

Ostrea Attwoodi. Gabb (?); Vol. II, pl. 11, fig. 58b.

Ostrea Tayloriana, Gabb; Vol. II, pl. 12, fig. 60.

Tapes truncata, Gabb; Vol. II, pl. 7, fig. 44.

Venus (Chione) pertenuis, Gabb; Vol. II, pl. 5, fig. 37.

Venus (Chione) Whitneyi, Gabb; Vol. II, pl. 5, fig. 40.

\section{PLIOCENE.}

Arca sulcicosta, Gabb; Vol. II, pl. 9, fig. 53.

Callista (Standella) Voyi, Gabb; Vol. II, pl. 5, fig. 41.

Gari (Psammocola) alata, Gabb; Vol. II, pl. 5, fig. 36.

Lucina (Here) Richthofeni, Gabb; Vol. II, pl. 8, fig. 49.

Zirphra dentata, Gabb; Vol. II, pl. 3, fig. 31, 31a.

\section{QUATERNARY.}

Cancellaria (Euclia) tritonidea, Gabb; Vol. II, pl. 2, fig. 18.

Clathurella Conradiana, Gabb (?); Vol. II, pl. 1, fig. 12.

Muricidea paucivaricata, Gabb; Vol. II, pl. 14, fig. 1.

Surcula (Pleurotoma) Carpenteriana, Gabb; Vol. II, pl. 1, fig 8.

Surcula (Pleurotoma) Tryoniana, Gabb; Vol. II, pl. 1, fig. 9.

Mercenaria perlaminøsa, Gabb; Vol. II, pl. 5, fig. 38.

Pecten Cerroensis, Gabb; Vol. II, pl. 9, fig; 55. 
On Malignite, a family of basic, plutonic, orthoclase rocks, etc.; by Andrew C. Lawson. Univ. of Cal., Bull. Dept. of Geology, Vol. 1, No. 12, pp. 371-428. Berkeley, 1896.

Șigmogomphius Le Contéi, a new castoroid rodent from the Pliocene, near Berkeley, Cal.; by John C. Merriam. Univ. of Cal., Bull. Dept. of Geology, Vol. 1, No. 13, pp. 363-370. Berkeley, 1896.

The Great Valley of California: a criticism of the theory of isostasy; by F. Leslie Ransome. Univ. of Cal., Bull. Dept. of Geology, Vol. 1, No. 14, pp.371-428. Berkeley, 1896.

The geology of Point Sal; by H. W. Fairbanks. Univ. of Cal., Bull. Dept. of Geology, Vol. 2, No. 1, pp. 1-92, pls. 1-2. Berkeley, 1896.

On some Pliocene Ostracoda fròm near Berkeley; by Frederick Chapman. Univ. of Cal., Bull. Dept. of Geology, Vol. 2, No. 2, pp. 93-100, plate 3 . 


\section{PART II.}

\section{Publications of the United States Government.}

\section{SENATE AND HOUSE DOCUMENTS.}

Report of the Exploring Expedition to the Rocky Mountains in 1842, and in Oregon and North California in the years 1843-44; by Bvt. Capt. J. C. Fremont, U. S. Army. Washington, 1845. 693 pp., 24 plates, and 3 maps. 28th Cong., $2 \mathrm{~d}$ sess., Senate Doc. 174.

The first part of this report was a reprint of the expedition of 1842. (Senate Doc. 243, 27th Cong., 3d sess., 1842.)

The report contains a few geological notes of California, and a description of the fossils, by James Hall. The specimens described are all from Muddy Creek, Wyoming.

Geographical memoir upon Upper California in illustration of his map of Oregon and California; by John Charles Frémont. Addressed to the Senate of the United States. Washington, 1848. 67 pp. map. (30th Cong., 1st sess., Senate Misc. Doc. 148.)

Map of Oregon and Upper California, from the surveys of John C. Frémont and other authorities. Drawn by C. Preuss under the order of the Senate of the United States. Washington, 1848. Scale, 1:3,000,000.

Notes of a military reconnoissance from Fort Leavenworth, in Missouri, to San Diego, in California; including parts of the Arkansas, Del Norte, and Gila Rivers; by Maj. W. H. Emory, U. S. Army. Washington, 1848. 416 pp. 41 plates and map. (30th Cong., 1st sess., Ex. Doc. 41.)

Report of Lieut.-Col. P. St. George Cooke of his march from Santa Fé, New Mexico, to San Diego, Upper California. Washington, 1848. 13 pp. and map. (30th Cong., 1st sess., Ex. Doc. 41, pp. 551-563.) 
Journal of Capt. A. R. Johnson, U. S. Army. (Expedition from Santa Fé to San Diego.) Washington, 1848. 48 pp. (30th Cong., 1st sess., Ex. Doc. 41, pp. 567-614.)

Journal of the march of the Mormon Battalion of Infantry Volunteers, under the command of Lieut.-Col. P. St. George Cooke, from Santa Fé, New Mexico, to San Diego, California. Washington, 1849. 85 pp. (30th Cong., spec. sess., Senate Doc. 2.)

United States Exploring Expedition, under the command of Charles Wilkes, U. S. Navy. Vol. X, Geology, by James D. Dana. Philadelphia, 1849. pp. xii, 9, and 756. 5 maps and folio atlas of 21 plates.

Only two bundred copies of this report were published. (Letter of J. D. Dana, September 2, 1890.)

The author gives an account of the geology of Shasta Mountains, also that of San Francisco Bay, with a description of the fossils of Astoria, Oregon.

A synopsis of this report was published in Wilkes's Western America, including California and Oregon, with maps of those regions and of "The Sacramento Valley," from actual surveys. Philadelphia, 1849.

\section{REPORTS OF THE SECRETARY OF WAR.}

Information in relation to the geology of California:

Report of P. T. Tyson upon the geology of California. 31st Cong., 1st sess., Senate Ex. Doc. 47. Washington, 1850. 74 pp. 9 sections and 1 map.

This report contains articles on the geology of part of the Sierra Nevada; geology of the Coast lange; geological structure of Sacramento Valley; review of the geological changes in California; gold regions of the Sierra Nevada; the quicksilver mines; other mineral resources, and their industrial applications.

Report by General Smith, dated October 7, 1849. pp. 75-108.

Report of Lieutenant Talbot to General Smith, dated October 5, 1849. pp. 108-116.

Report of Professor Frazer on minerals forwarded by General Smith; dated March 21, 1850. pp. 116-117. 
Report of General Riley, dated January 1, 1850. pp. 118119.

Report of Lieutenant Ord to General Riley, dated October 31, 1849. pp. 119-127.

Part 2. Report of the Secretary of War in further compliance with the resolution of the Senate, calling for copies of Report on the Geology and Topography of California. Washington, 1850. 37 pp., and 3 maps. (31st Cong., 1st sess., Senate Ex. Doc. 47.)

This report contains: A topographical memoir accompanying maps of the Sacramento Valley, etc.; by Lieut. G. H. Derby. pp. 2-16.

Reconnoissance made by Capt. W. H. Warner of a route through the Sierra Nevada by the upper Sacramento. pp. 16-34.

Exploration of Monte Diablo, and the valley lying between this mountain and the southern shore of Suisun Bay; by Lieut. R. S. Williamson. pp. 34-37:

(ieology and industrial resources of California; by Philip T. Tyson. Baltimore, 1851. xxxiv, 127, and 37 pp. 9 sections and three maps.

A republication of the above report, with an introduction and an index.

The Report of Secretary of War. 1850. (31st Cong., 2d sess., Senate Ex. Doc. 1.)

The report of Major D. H. Vinton contains an account of borings near Benicia. pp. 278-279.

T. Butler King's report on California. 1850. (31st Cong., 1st sess., Ho. of Rep. Ex. Doc. 59.)

This document was published in Washington in another form by Gideon \& Co., 1850. 72 pp. 8 vo.

The author gives an account of the geology of the Gold Regions.

Letter from Col. Richard B. Mason. (31st Cong., 1st sess., Ho. of Rep. Doc. 17, 1850, pp. 528-536.)

This letter is the first official report on the discovery of gold in California. Colonel Mason states that on the 12th of June, 1848, in company with Lieut. W. T. Sherman, he started on a tour through the northern part of California to visit the newly discovered gold placer region in the valley of the Sacramento. He gives a description of the country along the American River and an historical account of the mining regions. He also gives a description of the quicksilver mines near San José. 
Tour of the gold regions; by Bvt. Brig.-Gen. Bennett Riley. (31st. Cong., 1st sess., Ho. of Rep. Doc. 17, 1850, pp. 785-792.)

United States and Mexican Boundary Survey, under the orders of Lieut.-Col. W. H. Emory. Geology and Palæontology of the Boundary, by James Hall ; pp. 103-140, Part 2. Description of Cretaceous and Tertiary Fossils, by T. A. Conrad; pp. 141-165. (34th Cong., 1st sess., Senate Ex. Doc. 108. Washington, 1857.)

Chapter V contains description of the geology of Southern California, with a section of lignite bluff near San Diego.

Notes on route from near the Tejon Pass, through western New Mexico and the Colorado to Santa Fé in the fall of 1853; by Capt. F. C. Aubrey. 12 pp. [Published by Congress in 1854 and in the California journals.]

This was the route through the gold country on the head (southern) waters of the San Juan and the upper branches of the Rio Salodo, or Salinas, of the Gila River.

Report upon Pacific wagon roads. Washington, 1858. (35th Cong., 2d sess., Ho. of Rep. Ex. Doc. 108, Senate Doc. 36.)

Report of Survey on the Union and Central Pacific Railways; by W. T. Twining. Washington, 1875 . (44th Cong., $2 \mathrm{~d}$ sess., Ho. of Rep. Doc. 38.)

Mining débris in California. Preliminary report; by Col. Geo. H. Mendell. Submitted January 31, 1881.

Mining débris in California rivers. Letter of the Secretary of War. A final report upon the system to prevent further injury to the navigable waters of California from mining débris. 1882.110 pp. 2 maps. (47th Cong., 1st sess., Ho. of Rep. Ex. Doc. 98.)

Mining débris in California. Letter of the Secretary of War. Report of Board of Government Engineers respecting the adjustment of the conflict between the mining and farming sections, and the rehabilitation of the mining industry in California. 1891. 124 pp. 2 maps. (Ex. Doc. 267, H. R., 51st Cong., 2d sess.) 
The future of silver, by Suesis Edward; translated by Robert Stein, U. S. Geol. Survey. Washington, 1893. 101 pp. (53d Cong., 1st sess., Senate Misc. Doc. 95.)

The author gives a sketch of the California gold fields.

\section{U. S. NAVY DEPARTMENT.}

Letter from the Secretary of the Navy, inclosing report of experiments on the coal of the Pacific Coast, in compliance with a resolution of the House of March 22, 1872. (42d Cong., 2d sess., Ho. of Rep. Ex. Doc. 206.)

This report of Chief Engineer B. F. Isherwood, U.S. Navy, contains a report on the brown coal from Mount Diablo coal mines of California.

\section{REPORTS OF EXPLORATIONS AND SURVEYS}

\section{For a Railroad from the Mississippi River to the Pacific Ocean.}

Pacific Railroad Reports, Vol. III. Résumé of a geological reconnoissance, extending from Napoleon, at the junction of the Arkansas with the Mississippi, to the Pueblo de los Angeles, in California; by Jules Marcou. pp. 165175 .

This resumé was reprinted from the preliminary report of Lieutenant Whipple. Chap. VI, p. 40, House Doc. 129. Washington, 1855.

The report has a geological map of the route explored near the parallel of $35^{\circ}$ north latitude, from the Mississippi River to the Pacific Ocean.

Vol. V. Routes in California to connect with the routes near the 35 th parallel and $32 \mathrm{~d}$ parallel explored by Lieut. R. S. Williamson in 1853 . Geological report by William P. Blake. Washington, 1856. (33d Cong., 2d sess., Senate Ex. Doc. 78.)

This report contains general observations upon the geology of the route:

Chapter I. San Francisco to the San Joaquin River.

II. Grayson's Ferry, on the San Joaquin, to Fort Miller.

III. Fort Miller and the vicinity ; Fort Miller to Ocoya Creek. 
IV. Ocoya Creek to the Tejon.

V. Tejon to San Amedio; Cañada de las Uvas.

VI. Tejon to the Great Basin and Pass of San Francisquito ; Pass of San Francisquito to the Mojave River.

VII. Mojave River, by Williamson's Pass, to San Fernando and Los Angeles; Los Angeles to San Bernardino; Cajon Pass.

VIII. San Bernardino to the Colorado Desert; Colorado Desert to Carrizo Creek and Warner's Valley.

IX. Warner's to the Colorado Desert; Colorado Desert to the mouth of the Gila; Camp Yuma and the vicinity.

X. Fort Yuma to Carrizo Creek; Carrizo Creek to San Diego.

XI. Observations on the orography and general features of relief of the middle and southern portions of California.

XII. Geology of the vicinity of San Francisco.

XIII. Tertiary formations of Ocoya Creek, Monterey, and other localities.

XIV. Observations on the Tulare Valley.

XV. Geology of the Tejon Pass and Cañada de las Uvas; section of the Sierra Nevada.

XVI. Observations on the southern part of the Great Basin.

XVII. The Colorado Desert.

XVIII. Notes on the Gold Region.

XIX. Building materials; coal; lignite; bitumen.

XX. Metals, ores, and minerals.

Appendix, Article I. Notice of the fossil fish; by Louis Agassiz. pp. 313-316. plate 1.

The following species from Ocoya Creek are described and figured: Echinorhinus Blakei, n.sp.; Scymnus occidentalis, n.sp; Galeocerdo productus, n.sp.; Prionodon antiquus, n.sp.; Hemipristic heteropleurus, n.sp.; Carcharodon rectus, n.sp.; Oxyrhina plana, n.sp.; $O$. tumula, n.sp. ; Lamna clavata, n.sp.; L. ornata, n.sp.; Zygobates sp.?

Appendix, Article II. Descriptions of the fossil shells; by T. A. Conrad. pp. 317-329. plates 2-9.

From Cañada de las Uvas: Cardium linteum, n.sp.; Dosinia alta, n.sp.; Meretrix Uvasana, n.sp.; M. Californiana, n.sp.; Crassatella Uvasana, n.sp.; C. alta, Conrad; Mytilus humerus, n.sp.; Cardita planicosta; Natica oetites, Conrad; N. gibbosa, Lea; N. alveata; Turritella Uvasana, n.sp.; Volutatithes Californiana, n.sp.; Busycon? Blakei, n.sp.; Clavatula Californica, n.sp.

From Ocoya Creek: Meretrix decisa, n.sp.; Natica Ocoyana, n.sp. ; N. geniculata, n.sp.; Bulla jugularis, n.sp.; Pleurotoma transmontana, n.sp.; P. Ocoyana, n.sp.; Syctopus Ocoyana, n.sp.; Turritella Ocoyana, n.sp.; Colus arctatus, n.sp.; Tellina Ocoyana, n.sp.; Pecten Nevadanus, n.sp.; P. catilliformis, n.sp.; Cardium sp.?; Arca sp.?; Solen sp.?; Dosinia sp. ?; Venus sp. ?; Cytherea decisa, Conrad.

From San Diego: Cardium modestum, n.sp.: Nucula decisa, n.sp.; Corbula Diegoana, n.sp.; Tellina Diegoana, n.sp.; Mactra Diegoana, n.sp.; Narica Diegoana, n.sp.; Trochita Diegoana, n.sp.; Crucibulum spinosum, n.sp.

From Monterey County: Meretrix uniomeris, n.sp.; Tellina congesta, n.sp.; Modiola contracta, n.sp. 
From Tulare Valley: Meretrix Tularena, n.sp.; Arca microdonta, n.sp.; Stramonita petrosa, n.sp.

From San Pedro: Tellina Pedroana, n.sp.; Tapes diversum, n.sp.; Saxicava abrupta, n.sp.; Petricola Pedroana, n.sp.; Schizothorus Nuttalli, n.sp.; Mytilus Pedroana, n.sp.; Penitella spelxa, n.sp. (Recent); Fissurella crenulata, Sow.; Buccinum interstriatum?

From Carmello: Lutraria Traskei, n.sp.

From Colorado Desert: Pecten deserti, n.sp.; Anomia subcostata, n sp.; Ostrea vespertina, n.sp.; O. Heermanni, n.sp.; Anodonta Californiensis, Lea.

From San Fernando: Ostrea sp.? Pecten sp.?

From Benicia: Turritella biseriata, n.sp.; Trochus sp.?

Appendix, Article IV. Letter from Prof. J. W. Bailey, describing the structure of the fossil plant from Posuncula River. p. 337. (This plant was from a bowlder in the bed of Kern River, west slope of the Sierra Nevada.)

Pacific Railroad Reports, Vol. VI. Geological report of routes in California and Oregon explored by Lieuts. R. S. Williamson and H. L. Abbott; by John S. Newberry. (33d Cong., 2 d sess., Senate Ex. Doc. 78. 1857.)

This report contains the following:

Chapter I. Geology of the vicinity of San Francisco.

II. Geology of the Sacramento Valley.

III. Geology of the Western range, Sierra Nevada.

IV. Geology of Pit River and Klamath Basin.

Vol. VI, No. 2. Description of the Tertiary fossils collected on the survey; by T. A. Conrad.

The following species are described and figured in this report:

Schizopyga Californiana, n.sp., Santa Clara, Cal.

Cryptomya ovalis, n.sp., Monterey County.

Thracia mactropsis, n.sp., Monterey County.

Mya Montereyana, n.sp., Monterey County.

M.? subsinuata, n.sp., Monterey County.

Arcopagia medialis, n.sp., Monterey County.

Tapes linteatum, n.sp., California.

Arca canalis, n.sp., Santa Barbara.

A. trilineata, n.sp., Santa Barbara.

$A$. congesta, California.

Axincea Barbarensis, n.sp., Santa Barbara.

Mulinia densata, n.sp., Santa Barbara.

Dosinia longula, n.sp., Monterey.

D. alta, n.sp., Monterey.

Pecten Pabloensis, n.sp., San Pablo Bay.

Pallium estrellanum, n.sp., Estrella Valley.

Janira bella, n.sp., Santa Barbara.

Ostrea titan, n.sp., San Luis Obispo.

Malea ringens; Dolium ringens (Cassis), Swainson.

Turritella altilira, n.sp., Gatun, Isthmus of Darien.

T. Gatunensis, n.sp., Gatun. 
Triton, sp.?; Cytherea (Meretrix) Dariena; Tamiosoma gregaria, n.sp., Monterey County.

Pandora bilirata, n.sp., Santa Barbara.

Cardita occidentalis, n.sp., Santa Barbara.

Diadora crucibuliformis, n.sp., Santa Barbara.

The author discusses the age of the formation afterward called by the California geologists the Chico group. Newberry admits the Tertiary character of a part of the fossils, but is inclined to refer the formation to the Cretaceous, because of the presence in it of Ammonites, etc.

Pacific Railroad Reports, Vol. VII. Routes in California to connect with the routes near the 35 th and $32 \mathrm{~d}$ parallel and routes near the $32 \mathrm{~d}$ parallel, between the Rio Grande and Pimas villages, explored by John G. Parke in 1854-55. Geological report by Thomas Antisell. (33d Cong., 2 d sess., Senate Ex. Doc. 78. 1857.)

This report contains chapters on the physical geography of the Pacific Coast; geology of the Coast Ranges; Santa Clara Valley and Pajaro River Valley; Salinas River Valley; Santa Margarita Valley; Point Pinos Mountains and Sierra San José; Santa Maria River and Cuyama Valley; Santa Lucia Mountains; Valley of San Luis Obispo, Santa Barbara Mountains; geology of the Sierra Susanna and Monica; Plains of San Fernando; Los Angeles and San Bernardino; with the geology of the Cordilleras, etc.; Estrella River; Panza and Carrizo; Mojave River Valley; bituminous effusions; Quaternary period in California; geology of the district from San Diego to Fort Yuma, and from Fort Yuma to the Pimas villages; etc., etc.

Report on the Palæontology of the survey; by T. A. Conrad. Chapter XXIX, pp. 189-196, with 10 plates.

The author remarks that the Miocene of Santa Barbara contains a group of shells more analogous to the fossils of the Atlantic slope than to the existing shells of California; but it is evident that there must be subdivisions in the Tertiary deposits of California, which range between the Eocene and Pliocene periods, for the group of the Estrella Valley and Santa Ynez (Barbara) Mountains does not appear to contain one species, even, analogous to any in the Santa Barbara beds, and, on the contrary, some of them remind us of the existing Pacific fauna.

The author describes and figures the following new species:

From Santa Margarita, Salinas Valley : Hinnetes crassa.

From San Rafael Hills and Santa Barbara County: Pecten Meeki; P. altiplicatus; Arcopagia unda.

From Carrizo Creek, Colorado Desert, and Fstrella River Valley: Pecten deserti, Conrad; Pallium Estrellanum; Spondylus Estrellanus; Arcopagia unda; Cyclas Estrellana; Ostrea panzana; Glycimeris Estrellanus; Balanus Estrellanus; Astrodapsis Antiselli.

From Santa Ynez and Santa Ynez Mountains: Pecten discus; Pachydesma Inezana; Pecten magnolia; Crassatella collina; Mytilus 
Inezensis; Turritella Inezana; T. variata; Natica Inezana; Tapes Inezensis.

From San Buenaventura: Tapes montana.

From Pajaro River: Venus Pajaroana.

From Sierra Monica: Cyclas permacra; Ostrea subjecta.

From San Luis Obispo Valley: Arca Obispoana.

From Gaviota Pass: Ostrea panzano; Mactra? Gaviotensis; Trochita costellata.

From Salinas River, Monterey County: Dosinia alta; D. longula; D Montana; D. subobliqua.

From Ranch Triumpho, Los Angeles: Lutraria transmontana; Axinea Barbarensis.

Report of Mr. T. A. Conrad on the fossil shells collected in California by Wm. P. Blake, Geologist of the Expedition under the command of Lieut. R. S. Williamson, etc. Washington, 1855. 34 pp. (House Doc. 129.)

The fossils described in this report were afterward republished, with figures, in the fifth volume of Explorations and Surveys for a Railroad Route from the Mississippi River to the Pacific Ocean.

\section{REPORTS ON MINERAL RESOURCES OF THE STATES AND TERRITORIES WEST OF THE MISSISSIPPI.}

Report of 1867 ; by J. Ross Browne and James W. Taylor, U.S. Mining Commissioners. Washington, 1867. $360 \mathrm{pp}$.

Historical sketch of gold and silver mining on the Pacific Slope; by J. Ross Browne and J. W. Taylor. pp. 13-36.

Geological formation, etc., of Pacific Slope ; by William Ashburner. pp. 37-49. (Contains articles on the gold-mining interest of California; characteristics of the gold belt; northern mining district; mining in the Sierras.)

Condition of gold and silver mining on the Pacific Coast; by J. Ross Browne and James W. Taylor. pp. 49-85.

The copper resources of the Pacific Slope; geological formation in which copper is found; by J. Ross Browne and James IV. Taylor. Section V, pp. 138-169.

Quicksilver mines in California; New Almaden mines, products and exports. Section VI, pp. 170-178. (This article contains a description of the New Almaden mines, with extracts of a report by Prof. B. Silliman, Jr., from the Am. Jour. Sci. for September, 1864.)

Borax, sulphur, tin, and coal. Section VII, pp. 178-193. (Contains articles on the discovery of borax in California, etc.; reports on tin, from the Geological Survey of California, Vol.1, p. 180; with report on 
the coal mines of the West Coast of North America, by W. M. Gabb.)

Annotated catalogue of the principal mineral species hitherto recognized in California and adjoining States and Territories; by William P. Blake. Section IX, pp. 200-215. (This article also contains notes on the geological distribution and geology of the precious metals and valuable minerals on the Pacific Slope of the United States, with a section across the Mariposas.)

History of California ; by E. Randolph. pp. 268-305.

Acquisition of California; by John W. Dwinelle. pp. 306-320.

Report of 1868; by J. Ross Browne, U. S. Mining Commissioner. Washington, 1868. $674 \mathrm{pp}$.

General condition of the mining interest; by J. Ross Browne. pp. 12-298.

Lower California geographical and physical features; by W. M. Gabb. pp. 630-639.

So little is accurately known in regard to the geology of Lower California, that it seems desirable to include this notice and a list of the works on Lower California in this bibliography. The most important publications with regard to the geology of Lower California are:

1. Notes on the geology of Baja California, Mexico; by W. Lindgren. Proc. Cal. Acad. Sci., 2d series, Vol. 1, 1888, p. 173; Vol. 2, 1889, p. 1; Vol. 3, 1890, p. 26.

2. Some geological notes are also found in the reports of the Mexican boundary and Pacific Railway surveys.

3. Geological sketch of Lower California; by S. I. Emmons and G. P. Merrill. Bull. Geol. Soc. Am., Vol. 5, 1894, pp. 489-514, with map.

4. Explorations in the Cape Region of Baja Californir; by Gustav Eisen. Proc. Cal. Acad. Sci., Vol. 5, 1895, p. 733; map.

The Mother Lode of California. pp. 14-19.

Miscellaneous minerals of Pacific Coast. pp. 207-266.

Agricultural resources of California. pp. 266-281.

Treasure shipments ; precious metals, etc. pp. 289-298.

Report of 1869 ; by R. W. Raymond, U. S. Mining Commissioner. Washington, 1870. $256 \mathrm{pp}$.

This includes notes on the Almaden mines and a chapter on the Mother Lode of California.

Report of 1870 ; by R. W. Raymond, U. S. Mining Commissioner. Washington, 1870. $805 \mathrm{pp}$.

California mines; by W. A. Skidmore. pp. 13-87.

Dead rivers of California; by J. S. Hittell. pp. 63-67.

Report of 1870 ; by R. W. Raymond, U. S. Mining Commissioner. Washington, $1872.566 \mathrm{pp}$.

Chapter on California mines; by W. A. Skidmore. pp. 11-92.

1)eep placer mining in California; by W. A. Skidmore. pp. 52-90. List of stamp-mills in California. Chapter 16. 
Report of 1871 ; by R. W. Raymond. Washington, 1873. $566 \mathrm{pp}$.

Chapter on California; by W. A. Skidmore. pp. 13-140.

Diamonds in El Dorado County; by W. A. Goodyear. p. 27.

Report of 1872 ; by R. W. Raymond. Washington, 1873. $550 \mathrm{pp}$.

Chapter on California; by W.'A. Skidmore. pp. 7-107.

List of mining claims in California. pp. 102-107.

Treatment of gold-bearing ores in California; by G. F. Deetken. Chapter 11.

Pliocene rivers of California; by A. W. Bowman. Chapter 16.

Hydraulic mining in California; by Chas. Waldeyer. Chapter 17.

This report also contains a geological map of the United States, by C. H. Hitchcock and W. P. Blake; also, a map showing a portion of the mining region in Placer and El Dorado Counties, and maps of Slate Creek Basin, Sierra County.

Report of 1873 ; by R. W. Raymond. Washington, 1874. $585 \mathrm{pp}$.

Chapter on California; by W. A. Skidmore. pp. 13-154.

Quicksilver in California; by Chas. G. Yale. pp. 27-29.

Beach sands of Gold Bluff; by A. W. Chase. pp. 145-147.

Mining and metallurgy of quicksilver in California; by Louis Janin, Jr. Chapter 11.

The geological formation of iron deposits in California is given on p. 44, extract from James D. Hague and Clarence King's report of the Sierra Iron and Mining Company.

Report of 1874; by R. W. Raymond. Washington, 1875. $540 \mathrm{pp}$.

Chapter on California; by W. A. Skidmore. pp. 11-194.

Seam mining. p. 81 .

Geology of the Sierra Nevada in its relations to vein mining, with map and tabular exhibit of results of mining; by Amos Bowman. Chapter 18.

History of relative values of gold and silver. Chapter 19.

An abstract of Dr. J. G. Cooper's paper on the discovery of lignites in Amador County and other counties in the foothills of the Sierra Nevada is given on p. 75 .

Report of 1875 ; by R. W. Raymond. Washington, 1877. $519 \mathrm{pp}$.

Chapter on California; by W. A. Skidmore. pp. 3-131.

Quicksilver in California; by J. B. Randol. pp. 4-21.

Extinct rivers of the auriferous belt of California; by C. J. Brown. pp. 65-68.

Geology of Plumas County, with map; by J.A. Edman. pp.109-128. Petroleum in California ; by F. A. Clarke. pp. 21-22. 
Report of 1880. Statistics of production of the precious metals in the United States for 1880; by H. C. Burchard, Director of U.S. Mint. Washington, 1881. $443 \mathrm{pp}$.

Contains chapter on California mines, by W. A. Skidmore and Chas. G. Yale; Contributions to California geology, by Melville Attwood; Auriferous gravels, by Chas. G. Yale.

Report of 1881 ; by H. C. Burchard, Director of U. S. Mint. Washington, $1882 . \quad 765 \mathrm{pp}$.

Contains chapter on California mines, by A. M. Lawver; Milling of gold quartz, by Melville Attwood; Mining machinery in California, by Chas. G. Yale; Gold from sulphurets, by Melville Atwood; Auriferous gravels of California, by John Hays Hammond; Old river-beds of the Sierra Nevada of California, by Jas. J. McGillivray.

Report of 1882 ; by H. C. Burchard, Director of U. S. Mint. Washington, $1883 . ' 873 \mathrm{pp}$.

Contains chapter on California mines, by J.R. Hardenburg; Placer gold in California, by Henry G. Hanks.

Report of 1883 ; by H. C. Burchard, Director of U. S. Mint. Washington, 1884. $858 \mathrm{pp}$.

Contains chapter on California mines, by J. R. Hardenburg; Condition of mining in California, by W. A. Skidmore; Drift mining in California, by R. L. Dunn.

Report of 1884; by H. C. Burchard, Director of U. S. Mint. Washington, 1885. $644 \mathrm{pp}$.

Contains a chapter on California mining, by A. M. Lawver; Gold and silver mining in California, past, present, and prospective, by W. A. Skidmore; Forms in which gold occurs in nature, by W. P. Blake.

Reports of $1885,1886,1887,1888$; by Jos. P. Kimball, Director of U. S. Mint.

In each of these reports the chapter on California mining is by Israel Lawton.

Reports of $1889,1890,1891,1892$; by E. O. Leech, Director of U. S. Mint.

In each of these reports the chapter on California mining is by Chas. G. Yale, except in 1892, when it was by W. H. Dimond.

Reports of $1893,1894,1895$; by R. E. Preston, Director of U. S. Mint.

In each of these reports the chapter on California mining is by Chas. G. Yale. 


\section{UNITED STATES COAST' SURVEY.}

Report of 1855. Observations on the physical geography and geology of the coast of California from Bodega Bay to San Diego; by W. P. Blake. pp. 376-398. 4 plates.

Part 2. Geology of the principal bays and ports from Point Reyes to San Diego:

1. Punta de los Reyes. The end of the point composed of granite; form of the point; Tertiary strata; etc.

2. San Francisco. Golden Gate; character of the shores; rocks forming the points of the peninsula of San Francisco; sandstone strata uplifted; quarries; probable age; metamorphosed rock; erupted rocks and serpentine alluvial deposits; sand dunes; etc.

3. Monterey. Point Pinos; Cypress Point; San Carlos; Point Pinos of granite; Tertiary strata; fossils and infusoria; rocks of Cypress Point; granite and conglomerate; rock-formation of San Carlos Bay; Point Lobos.

4. San Luis Obispo and Sunta Barbara. Recent Tertiary strata; mountains, probably of sandstone; resemblance to volcanic rocks.

5. San Pedro and vicinity. Absence of mountain ridges; banks of Tertiary strata; sandstone with sun-cracks; disturbance of the strata ; fossils; bitumen.

6. San Diego. Tertiary strata forming rounded hills; Tertiary strata of the slope; fossils; trappean rock.

7. Islands near the coast. Probably composed of sandstone and shale; flexures of the strata of Santa Catalina; etc.

Notice of earthquake waves, etc.; by A. D. Bache. Idem, p. 342 ; also, in Report of 1862, p. 238.

\section{U. S. CENSUS REPORTS.}

Report on the physical and agricultural features of the State of California, with a discussion of the present and future of cotton production in the State; also, remarks on cotton culture in New Mexico, Utah, Arizona, and Mexico; by E. W. Hilgard. 10th U. S. Census Report, Vol. VI, part 2,1884 .

A general description of the geology of the State is given on page 8. The outlines of the physical geography of the State, pp. 7,83 . 
Report of mineral industries of the United States. 11th U. S. Census Report, 1890.

Contains special reports as follows: Gold and silver, by R. P. Rothwell; Quicksilver, by James B. Randol; Coal, by John H. Jones; Petroleum, by J.D. Weeks; Natural gas, by J. D. Weeks; Asphaltum, by E. W. Parker; Stone, by W. C. Day; Precious stones, by G. F. Kunz; Infusorial earth, by E. W. Parker; Chapter on California mines, by Chas. G. Yale.

\section{U. S. GEOGRAPHICAL AND GEOLOGICAL SUR- VEYS WEST OF THE 100TH MERIDIAN.}

Lieut. GEO. M. WHEELER, U. S. Corps of Engineers, in charge.

Vol. III, Part 1. Report on the geology of portions of Nevada, Utah, California, and Arizona, examined in the years 1871-72; by G. K. Gilbert. Washington, 1875.

Annual report of Lieut. George M. Wheeler, for the fiscal year ending June 30, 1876.

Annual report of Chief of Engineers. 1876. Appendix JJ.

Report on the geology of a portion of Southern California; by Jules Marcou. Idem, Appendix $\mathrm{H}_{1}$, pp. 378-392.

This report contains articles on the Pliocene rocks of Los Angeles; the sierra of Santa Monica; Sierra Madre; Pacona or Pacoima Cañon; geology of the vicinity of the San Fernando Mission; the San Fernando sierra; asphaltum and mineral oil near San Francisquito Ranch; Sierra Liebre and California desert; Tertiary rocks, Canada de las Uvas, Fort Tejon, and of California; glacial rocks of Southern California and Pike's Peak; mountain chains and their ages; Coast Range; sierras of San Fernando and Santa Monica; hills of Los Angeles, etc.

Report on the geological and mineralogical character of Southern California and adjacent regions; by Oscar Loew. Idem, Appendix $\mathrm{H}_{2}$, pp. 393-419.

Report on the geology of the mountain ranges from La Veta Pass to the head of the Pecos; by A. R. Conkling. Idem, Appendix $\mathrm{H}_{4}$, pp. 419-422. 
Report of 1877. Geological report on the portions of Western Nevada and Eastern California between the parallels $30^{\circ} 30^{\prime}$ and $38^{\circ} 30^{\prime}$; by A. R. Conkling. Report of Chief of Engineers, 1877, Appendix H, pp. 1285-1295.

The area examined is bounded on the north by a line drawn through Truckee, Cal., and Washoe City, Nev.; on the east by the Mount Davidson range and the Como Mountains; on the south by Job's Peak and Pyramid Peak; and on the west by the Western summit and the Truckee Rivers. Nearly all this region is covered by granites, with occasional outbursts of basaltic rocks. No fossils were found, except at Carson City, at the State Prison quarries.

\section{U. S. GEOLOGICAL AND GEOGRAPHICAL SUR- VEYS OF THE TERRI'TORIES.}

F. V. HAYDEN, U. S. Geologist, in charge.

Twelfth Annual Report of the U. S. Geological and Geographical Survey of the Territories. A report of progress of the exploration in Wyoming and Idaho for the year 1878. In two parts. Part I. Washington, 1883.

On page 132, Dr. White describes Productus giganteus, Martin, from McCloud River, Shasta County, California.

\section{UNITED STATES GEOLOGICAL SURVEY.}

J. W. POWELL, Director.

Report for 1883-84; by Albert Williams.

Contains: Report on coal fields of United States, pp. 14-143; Iron on the Pacific Coast, by C. G. Yale, pp. 286-290 ; Quicksilver reduction at New Almaden, by S. B. Christy, pp. 503-534; The asphaltum deposits of California, by E. W. Hilgard, pp. 938-948; with reports on other minerals.

Sixth Annual Report, 1884-85. Division of Mesozoic Invertebrates, by Charles A. White. pp. 72-74. 1885.

The author states his conclusions in regard to the Chico and Tejon groups, and the auriferous slate series of California. He gives the name of Wallala group to a Cretaceous formation in Mendocino County. 
Sixth Annual Report, 1884-85. Administrative report, by George F. Becker. pp. 67-70.

The author discusses the age and time of uplift of the Coast Range formations and the equivalency of different Aucella-bearing beds.

Report for 1885; by David T. Day.

Contains: Reports on coal of California, pp. 15-16; Petroleum, pp. 148-152 ; Iron on the Pacific Coast, by C. G. Yale, pp. 196-199; Quicksilver, pp. 284-296; with reports on other minerals.

Seventh Annual Report, 1885-86. Report on California division of geology, by George F. Becker. pp. 93-97. 1888.

References to the diabase pebbles, etc., at Steamboat Springs, Nev.; the relations of the early and the late Cretaceous of the Coast Ranges; the identity of the older strata of the Coast Ranges with the fossiliferous rocks at the southern end of the gold belt in the Sierra Nevada, and the age and history of the Chico and Tejon series, etc.

Report for 1886; by Dávid T. Day.

Contains: Quicksilver, pp. 160-168; with reports on other minerals.

Report for 1887; by David T. Day.

Contains: Quicksilver, pp.118-125; with reports on other minerals.

Report for 1888; by David T. Day.

Contains: Iron ores of Rocky Mountain division, by F. F. Chisolm, pp. 35-39; Quicksilver, pp. 97-107; with reports on other minerals.

Eighth Annual Report, 1889. Quaternary history of Mono Valley, California; by Israel C. Russell. pp. 261-394. 24 plates and 5 maps.

_ Geology of Lassen Peak District; by J. S. Diller. pp. 395-432. 7 plates.

This report contains an account of the geologic formations in the Lassen Peak district; auriferous slates series; carboniferous limestone; serpentine; age of the auriferous slate district. CretaceousChico beds, composition, distribution, age of the fossils, upper and lower limits. Miocene-Composition of the Miocene strata, distribution and relations, fossils found in the Miocene strata, hypsographic and climatic conditions during the Miocene. Pliocene-Upheaval of the Piedmont region, structure of the Sierras, etc.

- Summary of the quicksilver deposits of the Pacific Slope; by George F. Becker. pp. 961-985. 3 plates.

For list of contents, see Monograph XIII. 
Report for 1889-90; by David T. Day.

Contains: Quicksilver, pp.94-109; Petroleum, by Joseph D. Weeks, pp. 287-365; Borax, by Charles G. Yale, pp. 491-506; with reports on other minerals.

Report for 1891; by David T. Day.

Contains: Quicksilver, pp.117-125; with reports on other minerals.

Report for 1892; by David T. Day.

Contains: Quicksilver ore deposits, by George F. Becker, pp. 139168 ; with reports on other minerals.

Report for 1893; by David T. Day.

Contains : Quicksilver, pp.111-118; with reports on other minerals.

Report for 1894; by David T. Day.

The report forms Parts III and IV of the Sixteenth Annual Report of the Survey.

Fourteenth Annual Report, 1895. The rocks of the Sierra Nevada; by H. W. Turner. Washington, 1895. pp. 441-495. 'pls. 48-59.

The gold-silver veins of Ophir, California; by Waldemar Lindgren. pp. 249-284.

Tertiary revolution in the topography of the Pacific Coast; by J. S. Diller. pp. 403-433.

Fifteenth Annual Report, 1893-94.

Sketch of the geology of the San Francisco peninsula; by Andrew C. Lawson. pp. 399-476, pl. $\nabla$-xii.

Sixteenth Annual Report, 1894-95.

Parts III and IV contain reports on mineral resources. Part IV contains reports on the production of coal in 1894, by F. W. Parker, pp. 1-217; Petroleum, by Joseph D. Weeks, pp. 315-404; Asphaltum, by E. W. Parker, pp. 430-435; Stone, by William C. Day, pp. 436-510; with reports on other minerals.

On the Quaternary and Recent mollusca of the Great Basin, with descriptions of new forms; by R. Ellsworth Call. Introduction is a sketch of the Quaternary lakes of the Great Basin, by G. K. Gilbert. Bulletin No. 11, Vol. 2. Washington, 1885. 56 pp. 6 plates. 
On the Mesozoic and Cenozoic palæontology of California; by C. A. White. Bulletin No. 15, Vol. 3. Washington, 1885. $33 \mathrm{pp}$.

This report contains general remarks on the geology of the coast; the Shasta group; relations of the fauna of the auriferous slates to that of the Shasta group; the geological age of the Aucella-bearing strata of California; remarks on certain Californian fossils which have been identified with Eastern species; etc., etc.

Notes on the stratigraphy of California; by George F. Becker. Bulletin No. 19, Vol. 3. Washington, 1885. 28 pp.

This report treats of the metamorphic rocks of the Coast Ranges; the non-conformity between the Knoxville beds and the Chico; identity of the Mariposa and Knoxville beds; relation of the Cascades to the Sierra and the Coast Ranges of California; Mesozoic beds; Palrozoic rocks of California ; etc.

On new Cretaceous fossils from California; by C. A. White. Bulletin No. 22, Vol. 3. Washington, 1885. 25 pp. 5 plates.

The following species are described in this bulletin : Coralliochama, n.gen; C.Orcutti; Trochus (Oxystele) euryostomus; Nerita, sp.?; Cerithium Pillingi; C.totium; Sanctorum; Solarium Wallalensis.

Notes on the geology of California; by J. S. Diller. Bulletin No. 33, Vol. 5. Washington, 1886. 23 pp.

This bulletin contains articles on the character and distribution of the Carboniferous limestones; structure of the Sierra Nevada range; age of the faulting of the Sierra Nevada range; age of the auriferous slates; general distribution of the metamorphic, volcanic, and Cretaceous rocks; relations of the Sierra, Coast, and Cascade ranges.

On invertebrate fossils from the Pacific Coast; by Charles A. White. Bulletin No. 51, Vol. 8, 1889, pp. 433-532, pls. 1-14. ' (Abstract Am. Geologist, Vol. 5, 1890, pp. 109-110.)

This paper contains: 1 . New fossil mollusca from the Chico-Tejon series of California; 2. Equivalents of the Chico-Tejon series in Oregon and Washington; 3. Cretaceous fossils from Vancouver Island region; 4. Molluscan fauna of the Puget group; 5. Mesozoic mollusca from the southern coast of the Alaskan peninsula.

The earthquakes in California; by James E. Keeler. Bulletin No. 68. Washington, 1890. 25 pp.

Dictionary of altitudes in the United States (second edition); . compiled by Henry Gannett. Bulletin No. 76. Washington, 1891. 393 p.p. 
A late volcanic eruption in Northern California, and its peculiar lava; by J. S. Diller. Bulletin No.79. Washington, 1891. $33 \mathrm{pp} .17$ plates.

Correlation Papers: Cretaceous; by Charles A. White. Bulletin Yo. 82. Washington, $1891.273 \mathrm{pp} .3$ plates.

Correlation Papers: Eocene; by W. B. Clark. Bulletin No. 83. Washington, 1891. 173 pp. 2 plates.

Earthquakes in Cakifornia in $1890-91$; by E. S. Holden. Bulletin No. 95. Washington, 1892.

Earthquakes in California in 1892 ; by C. D. Perrine. Bulletin No. 112. Washington, 1893.

Earthquakes in California in 1893 ; by C. D. Perrine. Bulletin No. 114. Washington, 1894.

Earthquakes in California in 1894; by C. D. Perrine. Bulletin No. 129. Washington, 1895.

Contributions to the Cretaceous palæontology of the Pacific Coast. The fauna of the Knoxville beds; by Timothy W. Stanton. Bulletin No. 133. Washington, 1895. 85 pp., 20 plates.

This bulletin contains a definition of the Knoxville beds, geographic distribution, local developments in Tehama, Colusa, Lake, and Napa Counties, Mount Diablo, and other localities southward, etc., with descriptions of the following species:

BrachIOPODA-Rhynchonella Schucherti, n.sp.; R. Whitneyi, Gabb; Terebratella Californica, n.sp.; Terebratula, sp.?

Mollusca-Ostrea, sp.; Anomia senescens, n.sp.; Spondylus fragilis, n.sp.; Lima multilineata, n.sp.; Pecten Californicus, Gabb?; P. complexicosta, Gabb; Avicula (Oxytoma) Whiteavesi, n.sp.; Aucella Piochi, Gabb ; A. crassicollis, Keyserl ; Inoceramus ovatus, n.sp.; Modiola major, Gabb ; IYyoconcha Americana, n.sp.; Pinna, sp.?; Arca Tehamaensis, n.sp; A. textrina, n.sp.; Pectunculus? ovatus, n.sp.; Nucula Gabbi, n.sp.; N. Storrsi, n.sp.; Leda glabra, n.sp.; Cardiniopsis, n.gen ; C. unioides, n.sp.; Solemya occidentalis, n.sp.; Astarte corrugata, n.sp.; A. Californica, n.sp.; A. trapezoidalis, n.sp.; Opis Californica, n.sp.; Lucina ovalis, n.sp.; L. Colusaensis, n.sp.; Cyprina occidentalis, Whiteaves; Solecurtus ? dubius, n.sp.; Corbula? persulcata, n.sp.; C. filosa, n.sp.; Dentalium Californicum, n.sp.; IIelcion granulatus, n.sp.; Fissurella bipunctata, n.sp.; Pleurotomaria, sp.?; Turbo Paskentaensis, n.sp.; T. Wilburensis, n.sp.; T. trilineatus, n.sp.; T. Colusaenis, n.sp.; T. Morganensis, n.sp.; T. 7 humerosus, n.sp.; Amberleya Dilleri, n.sp.; Atresius liratus, Gabb ; Turritella, sp.?; Iypsipleura? occidentalis, n.sp.; H.gregaria, n.sp.; 
Cerithium Paskentaensis, n.sp.; C. strigosum, n.sp.; C., sp.? Aporrhais, sp.; Phylloceras Knoxvillensis, n.sp.; Lytoceras Batesi, Trask; Desmoceras Californicum, n.sp.; Olcostephanus (Simbirskites) mutabilis, n.sp.; O. (Polyptychites) trichotomus, n. sp.; Hoplites Hyatti, n.sp.; H. Storrsi, n.sp.; $H$. angulatus, n.sp.; $H$. crassiplicatus, n.sp.; $H$. Dilleri, n.sp.; Perisphinctes, sp.; Diptychoceras?, sp.; Crioceras latus, Gabb; Aptychus? Knoxvillensis, n.sp.; Belemnites impressus, Gabb; B. Tehamaensis, n.sp.; Belemnites, sp.

Monographs, Vol. XIII. Geology of the quicksilver deposits of the Pacific Slope, with atlas; by George F. Becker. Washington, 1888 . xix and 486 pp. 7 plates, with atlas of 14 sheets.

The general heading of the chapters of this work are as follows: Chapter I. Statistics and history.

II. Notes on foreign occurrence of quicksilver.

III. Sedimentary rocks.

IV. The massive rocks.

V. Structural and historical geology of the quicksilver belt. Appendix to Chap. V, Remarks on the genus Aucella, by C. A. White.

VI. Descriptive geology of the Clear Lake region.

VII. Descriptive geology of Sulphur Bank.

VIII. Descriptive geology of the Knoxville district.

IX. Descriptive geology of the New Idria district.

X. Descriptive geology of the New Almaden district.

XI. Descriptive geology of the Steamboat Springs district.

XII. Descriptive geology of the Oathill, Great Western, and Eastern districts.

XIII. Other deposits of the Pacific. Coast.

XIV. Discussion of the ore deposits.

$\mathrm{XV}$. On the solution and precipitation of cinnabar and other ores.

XVI. The origin of the ore.

XVII. Summary of results.

The report contains geological maps of the Oathill, Great Western, and Eastern districts; geological map of the Mayacmas range, with figures of foreign and American species of the genus Aucella.

Geological atlas of the United States.

The following atlas sheets of California have been issued:

Jackson, folio 11 . Washington, 1894. 4 sheets, with text.

Lassen Peak, folio 15. Washington, 1895. 3 sheets, with text.

Marysville, folio 17. Washington, 1895. 4 sheets, with text.

Smartsville, folio 18. Washington, 1895. 4 sheets, with text.

Placerville, folio 3. Washington, 1894. 4 sheets, with text.

Sacramento sheet. Washington, 1892. 4 sheets, with text.

Statistical Papers: Mineral resources of the United States; by Albert Williams. Report for 1883.

Contains: Iron on the Pacific Coast, p. 148; Quicksilver, pp. 387398; Clays of the Pacific Coast, p. 475; with reports on borax, coal, copper, iron, lead, nickel, salt, tin, and other minerals. 


\section{PART III.}

\section{Publications of Scientific Societies, and Periodicals.}

\section{AMERICAN ASSOCIATION FOR THE ADVANCE- MENT OF SCIENCE.}

Published at Salem, Massachusetts.

Vol. 1, 1849-Vol. 43, 1896.

On the characters and probable geological age of the sandstone formation of San Francisco; by W. P. Blake. Proc. Amer. Assoc. Adv. Sci., 9th Meeting, August, 1855, pp. 220-222.

On the grooving and polishing of hard rocks and minerals by dry sand; by W. P. Blake. Proc. Amer. Assoc. Adv. Sci., 9th Meeting, August, 1855, pp. 216-220.

Remarks upon the geology of California from observations in connection with the U.S. survey and explowations for a railroad route to the Pacific; by W. P. Blake. Proc. Amer. Assoc. Adv. Sci., 9th Meeting, August, 1855, pp. 222-225.

Studies in the formation of mountains in the Sierra Nevada, California; by John Muir. Proc. Amer. Assoc. Adv. Sci., 33d Neeting, at Hartford, 1874, pp. 49-64.

Address by Prof. Joseph LeConte, the retiring president of the Association. Theories of the origin of mountain ranges. Proc. Amer. Assoc. Adv. Sci., 42d Meeting, August, 1893.

Supplementary notes on the metamorphic series of the Shasta region of California; by J. P. Smith. Proc. Amer. Assoc. Adv. Sci., 44th Meeting, August, 1896, pp. 137-138. 


\section{AMERICAN JOURNAL OF CONCHOLOGY.}

Published at Philadelphia.

Vol. 1, 1865-Vol. 7, 1871.

Observations on certain Eocene fossils described as Cretaceous by Mr. W. M. Gabb in his report published in the Palæontology of California; by T. A. Conrad. Am. Jour. Conch., Vol. 1, 1865, pp. 362-365.

The author remarks that Mr. Gabb makes two divisions of his Cretaceous strata, A and B. The former is, doubtless, Cretaceous; and the latter, I am sure, will prove to be older Eocene. Fusus Californicus, Gabb, the author does not recognize as "my ? Clavatula Californica." Volutilithes Navarroensis belongs to "my genus Rostellites." Fusus Rémondi is a species of Perissolax allied to P. penita. Amauropsis alveata is a species of Globularia. Fiscus mamillatus is probably Sycotypus modestus, Conrad. Perissolax is a genus nearly related to Sycotypus. Chemnitzia Spillmani is very distinct from any species I described under that name. Aturia Mathewsoni is Atuira zic-zac. Dosinia elevata is Dosineopsis alta. D. Uvasana is Dione ovata, Rogers. Meekia sella is probably Cyprina bisecta. M.navis is a species of Yoldia. Mactra Asburneri is propbably M. albaria, Conrad. Nucula truncatatwo species are evidently confounded under this name. Leda protexta? -there are two species here united, neither of which is the protexta-one Eocene, the other Cretaceous.

A reply to these criticisms of Mr. Conrad is given by Mr. W. M. Gabb in the second volume, pp. 87-92.

Reply to Mr. Conrad's criticism on Mr. Gabb's report on the Palæontology of California; by W. M. Gabb. , Am. Jour. Conch., Vol. 2, 1866, pp. 87-92.

Further observations on Mr. Gabb's Palæontology of California; by T. A. Conrad. Am. Jour. Conch., Vol. 2, 1866, pp. $97-100$.

The author remarks that Volutilithes Navarroensis has the external sculpture and form of a species of Rostellites found in New Jersey. Perissolax, Gabb, is limited to one species, but it is very different from Busycon Blakei, Conrad. Hemifusus Horni, II. Cooperi, and H. Rémondi, Gabb, and Fusus mamillatus, Gabb, are members of my proposed genus Ficopsis. Amauropsis alveata, Gabb, is a member of Lamarck's genus Ampullina. Venericardia Horni, Gabb, is a very different variety from the $V$. planicosta. Hamites Vancouverensis I believe to be an Ancyloceras. Ptycoceras xquicostatus is more likely to be Hamites. Neptunea curvirostris I believe to represent an undescribed genus.

The controversy which, for a long time, was maintained between Conrad and Gabb as to the age of the Tejon rocks of California, 
referred by Conrad to the Eocene and by Gabb to represent the uppermost member of the Cretaceous (Division B of the California Reports), can be found in the following papers:

Conrad. Am. Jour. of Conchology, Vol. I (1865), pp. 362-5; Vol. II (1866), pp. 97-100; Am. Jour. Sci., Vol. XLIV (1867), pp. 376-7.

Gabb. Am. Jour. of Conchology, Vol. II (1866), pp. 87-92; Am. Jour. Sci., Vol. XLIV (1867), pp. 266-9; Proc. Cal. Acad. Nat. Sciences, Vol. III (1867), pp. 301-306.

Heilprin, in his article on the age of the Tejon rocks, etc., Proc. Acad. Nat. Sci., Phila., 1882, p. 196, remarks, in a footnote, "that Conrad finally yielded his position, but he has been unable to discover the evidence of such a change of opinion in any of that author's writings."

Descriptions of some secondary fossils from the Pacific States; by W. M. Gabb. Amer. Jour. Conch., Vol. 5, 1870, pp. 5-18, pls. $3-7$.

Orthoceras Blakei, Gabb; Ammonites Nevadanus, Gabb; A. Colfaxi, Gabb; A. Billingsianus, Gabb? ; Turbo regius, Gabb ?; T. elevatus, Gabb ; Pholadomya multilineata, Gabb ; P. Nevadana, Gabb ; Goniomya aperta, Gabb; Myacites depressus, Meek; Cardium arcxformis, Gabb; Astarte appressa, Gabb ; Cardinia ponderosa, Gabb ; Posidonomya Blatchleyi, Gabb; Pinna, sp.; Crassianella lingulata, Gabb; Lima (Plagiostoma), sp. undt.; Monotis circularis, Gabb; Pecten acutiplicatus, Meek; Plicatula perembricata, Gabb; Spirifer obtusus, Gabb.

The author publishes the opinion that all the Jurassic deposits of the Sierra Nevada and their vicinity were probably of Triassic age. (page 5.)

\section{THE AMERICAN NATURALIST.}

Published in Philadelphia.

Remarks on fossil shells from the Colorado Desert; by Robert E. C. Stearns. Am. Nat., Vol. 13, No. 3, March, 1879.

The author illustrates Physa humerosa, Gould; Tryonia protea, and varieties semi-fossil from Colorado Desert, California; Anodonta Californiensis, Lea; Amnicola longinqua, Gould; Anondonta, Owens River, Cal.; Anodonta, Bear River, Utah.

Mountain upthrusts; by C. A. White. Am. Nat., Vol. 22, 1888, pp. 399-408.

Notes on the glaciation of Pacific Coast; by G. F. Wright. Am. Nat., Vol. 21, 1887, pp. 250-256.

Mesozoic and Cenozoic realms in North America; by E. D. Cope. Am. Nat., Vol. 21, 1887, pp. 445-462. 
Across the Santa Barbara Channel; by J. Walter Fewkes. Am. Nat., Vol. 33, 1889, pp. 211-217, 387-394.

Includes references to some geologic features and history of Santa Cruz Island, and the origin of some sandstone bowlders near Santa Barbara.

\section{INTERNATIONAL CONGRESS OF GEOLOGISTS, AMERICAN COMMITIEE REPORTS, 1888.}

On nomenclature of Cenozoic formations; by Joseph LeConte. International Congress of Geologists, American Committee Reports, 1888, pp. 17-18; American Geologist, Vol. 2, 1888 , pp. 283-284.

Reference to the nomenclature of the Tertiary and the position of Cenozoic unconformity in California.

\section{THE AMERICAN GEOLOGIST.}

Published at Minneapolis, Minn.

Vol. 1, 1888-Vol. 17, 1896.

Flora of coast islands of California, in relation to recent changes of physical geography; by Joseph LeConte. Am. Geol., Vol. 1, 1888, pp. 76-81.

Lavas of Northern California; by J. S. Diller. Am. Geol, Vol. 1, 1888, pp. 125-126. (From Am. Jour. Sci., Jan., 1887, Vol. 33, pp. 45-50.)

Describes beds of volcanic ash in place, inclosing the stumps of more or less decayed trees, the nature, origin, and occurrence of which is discussed at length.

Effects of pressure of a continental glacier; by A. Winchell. Am. Geol., Vol. 1, 1888, pp. 139-143.

The views here enunciated were published in the University Argonaut, in March, 1886.

Glacial action on flanks of higher Sierra Nevada. Am. Geol., Vol. 3, 1889, pp. 340-341.

This is an editorial note of the glacial planing on Upper and Lower Sardine Lakes, near Young America Mine. 
Notes on the geology and scenery of the islands forming the southern line of the Santa Barbara Channel; by Dr. L. G. Yates. Am. Geol., Vol. 5, 1890, pp. 43-52.

Geology of the Mother Lode gold belt; by H. W. Fairbanks. Am. (ieol., Vol. 7, 1891, pp. 209-222.

The pre-Cretaceous age of the metamorphic rocks of the California Coast Range; by H. W. Fairbanks. Am. Geol., Vol. 9, 1892, pp. 153-166.

Notes on a further study of the pre-Cretaceous rocks of the California Coast Ranges; by H. W. Fairbanks. Am. Geol., Vol. 11, 1893, pp. 69-84. plate.

Some recent contributions to the geology of California; by H. W. Turner. Am. Geol., Vol. 11, 1893, pp. 307-324.

Geological notes on the Sierra Nevada, Part 1; by H. W. Turner. Am. Geol., Vol. 13, 1894, pp. 228-249.

Geological notes on the Sierra Nevada, Part 2 ; by H. W. Turner. Am. Geol., Vol. 13, 1894, pp. 297-316.

Notes on some localities of Mesozoic and Palæozoic, in Shasta County, California; by H. W. Fairbanks. Am. Geol., . Vol. 14, 1894, pp. 25-31.

This report contains notes on the Trias of Squaw Creek, the Carboniferous of the McCloud River, and the Devonian of the Sacramento River, near Kennett Station.

Notes on the geology of the Coast Ranges of California; by H. W. Turner and T. W. Stanton. Am. Geol., Vol. 14, 1894, pp. 92-98.

A contribution to the geology of the Coast Ranges; by Andrew C. Lawson. Am. Geol., Vol. 15, 1895, pp. 342-356. "

Auriferous gravels of the Sierra Nevada; by H. W. Turner. Am. Geol., Vol. 15, 1895, pp. 371-379.

Notes on the geology of Eastern California; by Harold WT. Fairbanks. Am. Geol., Vol. 17, 1896, pp. 63-74.

The mineral deposits of Eastern California; by Harold W. Fairbanks. Am. Geol., Vol. 17, 1896, pp. 144-158. 


\section{AMERICAN JOURNAL OF SCIENCE AND ARTS.}

\section{Published at New Haven, Conn.}

1st series: Vol. 1, 1819-Vol. 50, 1845.

2d series: Vol. 1, 1846-Vol. 50, 1870.

3d series: Vol. 1, 1871-Vol. 50, 1896.

California, elevation of, during the Tertiary epoch; by T. A. Conrad. Am. Jour. Sci., 1st ser., Vol. 35, 1839, p. 245.

In the author's article, "Notes on American Geology," in this journal, the author remarks: "On the coast of California Mr. Nuttall found shells of recent species two hundred feet above the sea. These are so much more remote from the axis of elevation than the Tertiary shell of New York that the uplift of the Rocky Mountains must have been far greater during the upper Tertiary period than was any part of the Atlantic chain."

Fossil shells from the Tertiary deposits on the Columbia River, near Astoria; by T. A. Conrad. Am. Jour. Sci., 2d ser., Vol. 5, 1848, pp. 432-433. 14 woodcuts.

The author describes and figures the following fossils, principally from cement-stone bowlders at Astoria, Oregon: Nucula devaricata, n.sp.; N. cuneiformis, n.sp.; N.abrupta, n.sp.; Mactra albaria, n.sp.; Tellina Oregonensis, n.sp.; T. obruta, n.sp.; Loripes parilis, n.sp.; Cytherea Oregonensis, n.sp.; C.vespertina, n.sp.; Nucula penita, n.sp.; Bullina petrosa, n.sp.; Pyrula modesta, n.sp.; Fusus Oregonensis, n.sp.; Solen curtus, n.sp.

The following species were collected by the writer at Astoria, and sent to the American Museum at New York. As the list is unpublished, it may be well to include it as a note to Mr. Conrad's paper: Nucula devaricata, Con.; N. impressa, Con.; Tellina albaria, Con.; Solemya ventricosa, Con.; Pecten propatulus, Con.; Area devincta, Con.; Venus bisecta, Con.; Pectunculus nitens, Con.; Venus angustifrons, Con.; Tellina emacerata, Con.; T. arctata, Con.; Lucina aculitmeata, Con.; Cardita sublenta, Coǹ.; Terebratula nitens, Con.; Dolium petrosium, Con.; Rostellaria indurata, Con.; Fusus geniculus; Sigeretus (Lumatia) scopulosa; Teredo substriatus; $A$ dentalium; Naulitus angulatus, Con. Besides these there are three or four species of bivalves and four of Gasteropods, undetermined, and one Brachipod. These fossils were collected from the cement stones and argillaceous shales; all belong to one geological period, as the same species are found in each to some extent, though most are different.

Mines of cinnabar in Upper California; by C. S. Lyman. Am. Jour. Sci., 2d ser., Vol. 6, 1848, pp. 270-271.

Gold in California. Amer. Jour. Sci., $2 d$ ser., Vol 7, 1848, pp. 125 and 262. 
Notes on Upper California, by James D. Dana, from observations made during the cruise of the U. S. exploring expedition, under Capt. Charles Wilkes, U. S. N. Am. Jour. Sci., 2d ser., Vol. 7, 1848, pp. 247-264.

Observations on California ; by Rev. C. S. Lyman. Am. Jour. Sci., $2 d$ ser., 1848 , p. 291, also 305 and 307.

Platinum and diamonds in California. Am. Jour. of Sci., $2 \mathrm{~d}$ ser., Vol. 7, 1848, p. 294.

California gold region; by Rev. C. S. Lyman. Am. Jour. Sci., 2d ser., Vol. 8, 1849, p. 415.

Gold of California; by Rev. C. S. Lyman. Am. Jour. Sci., $2 d$ ser., Vol. 9, 1849, p. 126.

Observations on the Pluton geysers of California; by Forest Shepherd. Am. Jour. Sci., 2d ser., Vol. 12, 1851, pp. 153-158.

On the Diluvial or Quaternary deposits in California; by James Blake. Am. Jour. Sci., 2 d ser., Vol. 13, 1852, pp. 385-391.

Notes on the Almaden mine, California; by T. S. Hart. Am. Jour. Sci., 2d ser., Vol. 16, 1853, pp. 137-139.

Infusoria of California. Ehrenberg (Monatsb. d. k. Pr. Akad. Wiss., Berlin, Aug., 1852, p. 528) gives the list published in Am. Jour. Sci., 2d ser., Vol. 16, 1853, p. 134.

On some new localities of fossil Diatomaceæ in California; by J. W. Bailey. Am. Jour. Sci., $2 d$ ser., Vol. 17, 1854, pp. 179-180.

Quicksilver mines of Almaden, California; by W. P. Blake. Am. Jour. Sci., $2 d$ ser., Vol. 17, 1854, pp. 438-440.

Recent earthquake shocks in California. Letter of W. P. Blake, in Am. Jour. Sci., 2 d ser., Vol. 17, 1854, p. 151.

Account of some volcanic springs in the Desert of the Colorado, in Southern California; by John L. Le Conte. Am. Jour. Sci., 2d ser., Vol. 18, 1855, pp. 1-6. 
Observations on the extent of the gold regions of California and Oregon, with notices of mineral localities in California and some remarkable specimens of crystalline gold; by W. P. Blake. Am. Jour. Sci., 2d ser., Vol. 20, 1855 , pp. $72-85$.

Earthquakes in California during the year 1856; by Dr. J. B. Trask. Am. Jour. Sci., 2 d ser., Vol. 23, 1857, pp. 341346.

Fossil plants of recent formations; by Leo Lesquereux. Am. Jour. Sci., 2d ser., Vol. 27, 1859, pp. 359-363.

On the direction and velocity of the earthquake, in California, of January 9, 1857; by John B. Trask. Am. Jour. Sci., $2 d$ ser., Vol. 25, 1858, pp. 146-148.

Progress of the Geological Survey of California; by J. D. Whitney. Am. Jour. Sci., 2 d ser., Vol. 38, 1864, pp. 256-264.

Notes on the New Almaden quicksilver mines; by B. Silliman, Jr. Am. Jour. Sci., 2d ser., Vol. 38, 1864, pp. 190-194.

Notice of the explorations of the Geological Survey of California, in the Sierra Nevada, during the summer of 1864; by J. D. Whitney. Am. Jour. Sci., 2d ser., Vol. 39, 1865, pp. 10-13.

Petroleum in California; by B. Silliman, Jr. Am. Jour. Sci., 2 d ser., Vol. 39, 1865, p. 101, also p. 341.

On the deep placers of the South and Middle Yuba, Nevada County, California, in connection with the Middle Yuba and Eureka Lake Canal Companies; by B. Silliman, Jr. Am. Jour. Sci., 2d ser., Vol. 40, 1865, pp. 1-19.

On the borax in California; by J. D. Whitney. Am. Jour. Sci., $2 d$ ser., Vol. 41, 1866, pp. 255-258.

Alleged discovery of an ancient skull in California; by W. H. B. Am. Jour. Sci., 2d ser., Vol. 42, 1866, p. 424.

On the naphtha and illuminating oil from heavy California tar (maltha); by B. Silliman, Jr. Am. Jour. Sci., 2d ser., Vol. 43, 1867, pp. 242-246. 
Note upon the occurrence of fossil remains of the tapir in California; by W. P. Blake. Am. Jour. Sci., 2d ser., Vol. 45,1868, p. 381.

The remains of a tapir occur in the auriferous gravel of Wood's Creek, near Sonora, Tuolumne County.

Reply to MIr. Gabb on the Cretaceous rocks of California; by T. A. Conrad. Am. Jour. Sci., $2 d$ ser., Vol. 44, 1867, pp. 376-377.

On the subdivisions of the Cretaceous rocks of California; by IV. M. Gabb. Am. Jour. Sci., 2d ser., Vol. 44, 1867, pp. 226-229.

On human remains along with those of the mastodon in the drift of California; by Dr. C. F. Winslow. Am. Jour. Sci., 2d ser., Vol. 46, 1868, p. 407.

Notes on the chemical geology of the gold fields of California; by J. Arthur Phillips. (Proc. Roy. Soc., Vol. XVI, p. 294.) Am. Jour. Sci., 2d ser., Vol. 47, 1869, pp. 134-139.

On the supposed absence of northern drift from the Pacific Slope of the Rocky Nountains; by Dr. Robert Brown. Am. Jour. Sci., 2d ser., Vol. 50, 1870, pp. 318-324.

On the discovery of actual glaciers on the mountains of the Pacific Slope; by Clarence King. Am. Jour. Sci., 3d ser., Vol. 1, 1871, pp. 157-167.

Notice of a fossil forest in the Tertiary of California; by O. C. Marsh. Am. Jour. Sci., 3d ser., Vol.1, 1871, pp. 266-268.

On the Owen's Valley earthquake; by J. W. Whitney. Am. Jour. Sci., 3d ser., Vol. 4, 1872, pp. 316-318. (From the Overland Monthly, August and September numbers, 1872.)

Le Conte, Joseph. Theory of formation of great features of the earth's surface. Am. Jour. Sci., 3d ser., Vol. 4, 1872, pp. $345-460$.

- Note in Vol. 5, 1873, p. 156.

Reply to Prof. T. Sterny Hunt. Vol. 5, 1873, p. 448. 
On some of the ancient glaciers of the Sierras; by Joseph Le Conte. Am. Jour. Sci., 3d ser., Vol. 5, 1873, pp. 325-342. map.

On the Klamath River mines: remarkable gravel deposits of the Lower Klamath-a sketch of their geology; by A. W. Chase. Am. Jour. Sci., 3d ser., Vol. 6, 1873, pp. 56-59.

On the great lava-flood of the West, and on the structure and age of the Cascade Mountains; by Joseph Le Conte. Am. Jour. Sci., 3d ser., Vol. 7, 1874, pp. 167-180; also pp. 259-267. See also Proc. Cal. Acad. Sci., Vol. 5, 1873, p. 214.

On the auriferous gravel deposits of Gold Bluff; by A. W. Chase. Am. Jour. Sei., 3d ser., Vol. 7, 1874, pp. 379-384.

On the probable existence of microscopic diamonds, with zircons and topaz, in the sands of hydraulic washings in California; by B. Silliman. Am. Jour. Sci., 3d ser., Vol. 5, 1873, pp. 384-385; see also p. 133 of Vol. 6.

On actual glaciers in California; by John Muir. Am. Jour. Sci., 3d ser., Vol. 5, 1873, pp. 69-71. (From the Overland Monthly for December, 1872.)

On mountain sculpture in the Sierra Nevada, and the method of glacial erosion; by E. S. Carr. Am. Jour. Sci., 3d ser., Vol. 7, 1874, pp. 515-516. (From the Overland Monthly for May, 1874.)

Ancient glaciers of Sierra Nevada in Lake Valley; by J. Le Conte. Am. Jour. Sci., 3d ser., Vol. 10, 1875, p. 126. See also Proc. Cal. Acad Sci., Vol. 5, 1873.

On the evidence of horizontal crushing in the formation of the Coast Range of California; by Joseph Le Conte. Am. Jour. Sci., 3d ser., Vol. 11, 1876, pp. 297-304.

Formation of Coast Ranges; by J. Le Conte. Am. Jour. Sci., 3d ser., Vol. 11, 1876, p. 297.

The age of the Tejon group, California; by Dr. J. G. Cooper. Am. Jour. Sci., 3d ser., Vol. 14, 1877, p. 321. (From Próc. Cal. Acad. Sci., Nov. 16, 1874.) 
On the structure and origin of mountains, with special reference to recent objections to the contraction theory; by Joseph Le Conte. Read before the National Academy of Science. Am. Jour. Sci., 3d ser., Vol. 16, 1878, pp. $95-112$.

Volcanoes about Lake Mono, and their relation to the glacier drifts; by Joseph Le Conte. Am. Jour. Sci., 3d ser., Vol. 18,1879 , pp. 35-44.

The relation of secular rock disintegration to Lœss glacial drift and rock basins; by Ráphael Pumpelly. Am. Jour. Sci., 3d ser., Vol. 17, 1879, pp. 138-144.

See note on p. 139, regarding California rocks.

Iono volcanoes, and relation to glacial epoch; by Joseph Le Conte. Am. Jour. Sci., 3d ser., Vol. 18, 1879, p. 79.

The old river-beds of California; by Joseph Le Conte. Am. Jour. Sci., 3d ser., Vol. 19, 1880, pp. 176-190.

Origin of jointed structure in undisturbed clay and marl deposits; by John Le Conte. Am. Jour. Sci., 3d ser., Vol. 23, 1882, pp. 233-234.

The phenomena of metalliferous vein formation now in progress at Sulphur Bank, California; by Joseph Le Conte and W. B. Rising. Am. Jour. Sci., 3d ser., Vol. 24, 1882, pp. 23-33.

The relations of the mineral belts of the Pacific Slope to the great upheavals; by George F. Becker. Am. Jour. Sci., 3d ser., Vol. 2S, 1884, pp. 209-212.

The geometrical form of volcanic cones and elastic limit of lava; by George F. Becker. Am. Jour. Sci., $3 \mathrm{~d}$ ser., Vol. 30, 1855, pp. 283-293.

On mineral vein formation now in progress at Steamboat Springs, compared with some at Sulphur Bank; by Joseph Le Conte. Am. Jour. Sci., 3d ser., Vol. 25, 1883, pp. 424-428.

On the genesis of metalliferous veins; by Joseph Le Conte. Am. Jour. Sci., 3d ser., Vol. 26, 1883, pp. 1-19. 
On origin of bitumen; by S. F. Peckham. Am. Jour. Sci., 3d ser., Vol. 28, 1884, pp. 105-117.

Cretaceous metamorphic rocks of California; by George F. Becker. Am. Jour. Sci., 3d ser., Vol. 31, 1886, pp. 348357.

A Post Tertiary elevation of the Sierra Nevada, shown by the river-beds; by Joseph Le Conte. Am. Jour. Sci., 3d ser., Vol. 32, 1886, pp. 167-181.

Notes on the geology of Northern California; by J. S. Diller. (Abstract of paper from the Proc. Phil. Soc. of Washington.) Am. Jour. Sci., 3d ser., Vol. 33, 1887, pp. $152-153$.

The latest volcanic eruption in Northern California, and its peculiar lava; by J. S. Diller. Am. Jour. Sci., 3d ser., Vol. 33,1887 , pp. 45-50.

The texture of massive rocks; by George F. Becker. Am. Jour. Sci., 3d ser., Vol. 33, 1887, pp. 50-58. (Abstract from Popular Science Monthly, Vol. 31, 1887, pp. 425-426.)

Discusses the relation of texture in igneous rocks to the conditions under which they were cooled, etc. The author also restates his conclusions in regard to the disputed age and relations of the Washoe rocks.

The flora of the coast islands of California, in relation to recent changes of physical geography; by Joseph Le Conte. Am. Jour. Sci., 3d ser., Vol. 34, 1887, pp. 457-460. See also, Cal. Acad. Sci. Bull., Vol. 2, 1887, pp. 515-520; Am. Geol., Vol. 1, 1888, pp. 76-81; Nature, Vol. 37, 1887, p. 358.

A discussion of the Post Tertiary physical changes of the coast region of California, as indicated by the flora and fauna of the coast islands.

On the occurrence of Hanksite in California; by Henry ( $\dot{ }$. Hanks. Am. Jour. Sci., 3d ser., Vol. 37, 1889, pp. 63-66. 
On the origin of normal faults and the structure of the basin region; by Joseph Le Conte. Am. Jour. Sci., 3d ser., Vol. 38,1889 , pp. 257-263.

Origin and mechanism of faults, especially those of the Great Basin.

Notes on the Cretaceous rocks of Northern California; by J. S. Diller. Am. Jour. Sci., 3d ser., Vol. 40, 1890, pp. 476478 .

The validity of the so-called Wallala beds as a division of the California Cretaceous; by H. W. Fairbanks. Am. Jour. Sci., 3d ser., Vol. 45, 1893, pp. 473-478.

Discovery of Devonian rocks in California; by J. S. Diller and Charles Schuchert. Am. Jour. Sci., 3d ser., Vol. 47, 1894, pp. 416-422.

An auriferous conglomerate of Jurassic age from the Sierra Nevada; by W. Lindgren. Am. Jour. Sci., 3d ser., Vol. 48, 1894, pp. 275-280.

Lower Cambrian rocks in Eastern California; by Chas. D. Walcott. Am. Jour. Sci., 3d ser., Vol. 49, 1895, pp. 141-144.

Some reptilian remains from the Triassic of Northern California; by J. C. Merriam. Am. Jour. Sci., 3d ser., Vol. 50, 1895, pp. 55-57.

The author describes the saurian remains of two individuals from black Triassic limestone of Shasta County under the name of Shastasaurus pacificus, n. gen. et sp. nov.

\section{THE AMERICAN MINING GAZE'TTE.}

\section{Published at New York City.}

Gold; its discovery and progressive development in the United States. Am. Min. Gazette, Vol 1, 1864, pp. 221-235.

The Mariposa estate. Am. Min. Gazette, Vol. 1, 1864, p. 431. 


\title{
ANNALS OF THE NEW YORK LYCEUM OF NATURAL HISTORY.
}

\author{
Published at New York City. \\ 1st Series: Vol.1, 1824-Vol.11, 1876.
}

Catalogue of shells collected at Panama, with notes on synonymy, station, and habitat; by C. B. Adams. Ann. N. Y. Lyceum of Nat. Hist., Vol. V, 1852, pp. 229-548. (Also published separately.)

The author gives full notes and descriptions, but no illustrations. Out of nearly 500 species, over 100 were new; but few of them extend to California, though many of the species are found living or fossil farther north.

\section{BULLE'TINS OF THE GEOLOGICAL SOCIE'TY OF AMERICA.}

Vol. 1, 1890-Vol. 6, 1894.

Orographic movements of the Rocky Mountains; by S. F. Emmons. Bull. Geol. Soc. of America, Vol. 1, pp. 245-286. April 7, 1890.

Sandstone dikes; by J. S. Diller. Bull. Geol. Soc. of America, Vol. 1, pp. 411-442, pls. 6-8. April 21, 1889.

The structure of a portion of the Sierra Nevada of California; by George F. Becker. Bull. Geol. Soc. of America, Vol. 2, pp. 49-74. January 10, 1891.

Antiquities from under Tuolumne Table Mountain in California; by George F. Becker. Bull. Geol. Soc. of America, Vol. 2, pp. 189-200, pl. 7. February 20, 1891.

Notes on the Early Cretaceous of California and Oregon; by George F. Becker. Bull. Geol. Soc. of America, Vol. 2, pp. 201-208. February 20, 1891.

Tertiary and Post Tertiary changes of the Atlantic and Pacific Coasts, with a note on the mutual relations of land elevation and ice accumulation during the Quaternary 
period; by Joseph Le Conte. Bull. Geol. Soc. of America, Vol. 2, pp. 323-330. March 16, 1891.

The geology of Mount Diablo, California; by H. W. Turner. With a supplement on the chemistry of the Mount Diablo rocks; by W. H: Melville. Bull. Geol. Soc. of America, Vol. 2, pp. 383-414, pl. 15. Narch 30, 1891.

Geology of the Taylorville region of California; by J. S. Diller. Bull. Geol. Soc. of America, Vol. 3, pp. 369-394. July 15, 1892.

Jura and Trias at Taylorville, California; by Alpheus Hyatt. Bull. Geol. Soc. of America, Vol. 3, pp. 395-412. July $15,1892$.

Stratigraphy and succession of the rocks of the Sierra Nevada of California; by James E. Mills. Bull. Geol. Soc. of America, Vol. 3, pp. 413-444, pl. 13. August 8, 1892.

Cretaceous and Early Tertiary of Northern California and Oregon; by J. S. Diller. Bull. Geol. Soc. of America, Vol. 4, pp. 205-224, pl. 4. April 14, 1893.

The faunas of the Shasta and Chico formations; by T. W. Stanton. Bull. Geol. Soc. of America, Vol. 4, pp. 245-266. June 8, 1893.

Two Neocene rivers of California; by W. Lindgren. Bull. Geol. Soc. of America, Vol. 4, pp. 257-298, pl. 5-9. June $19,1893$.

Age of the auriferous slates of the Sierra Nevada; by James P. Smith. Bull. Geol. Soc. of America, Vol. 5, pp. 243-258. February 27, 1894.

Trias and Jura in the Western States; by "Alpheus Hyatt. Bull. Geol. Soc. of America, Vol. 5, 1894, pp. 395-434.

The author places the relative age of the rocks of California, in different localities, as follows:

Trias-American and Sailor's Cañons.

Lower Jura-Inyo County, Cal.; Taylorville, Cal.

Middle Jura-Taylorville, Cal. Cal.

Upper Jura-Taylorville, Cal.; Mariposa Basin. Cal.; Colfax Basin, 
The following new species of fossils are described, but not figured: From American Cañon: Monotis semplicata; M. symmetrica.

From Sailor's Cañon: Daonella? subjecta ; D. böchiformis; D. cardinoides; Hemientolium? sp.?; Panopea? sp.?; Entolium sp.?; Gryphaca sp.?

Upper Jura fossils of the gold belt slates: Cardioceras dubium, Texas Ranch, Calaveras County; Perisphinctes virgulatiformis, near Reynolds Ferry; Perisphinctes sp.?, the same; P. filiplex?, Quenstedt, Tuolumne River, etc.; $P$. Colfaxi, Gabb, one mile west of Colfax; $P$. Mühbachi, El Dorado County; Olcostephanus Lindgreni, near Colfax; Oecotrautes denticulata, Stanislaus River; Belemnites Pacificus, Gabb, Mariposa County, American Cañon; Avicula sp.?, Stanislaus River; Amusium aurarium, Meek, six miles from Copperopolis; Aucella Erringtoni, Meek, var. arcuata, Tuolumne River, etc.; A. elongata, Stanislaus River; var. Elongata orbicularis, A. aviculeformis, near Reynolds Ferry; var. acuta, six miles from Copperopolis; A. orbicularis, Calaveras County.

The Shasta-Chico series; by J. S. Diller and T. W. Stanton. Bull. Geol. Sci. of America, Vol. 5, pp. 435-464. April 12, 1894 .

The authors give the following conclusions: That the discovery of Coralliochama Orcutti, in the basal portion of the Chico beds, in the Sacramento Valley, demonstrates that the Wallala beds are only a phase of the Chico. The Shasta-Chico series is composed of the Knoxville, Horsetown, and Chico beds, which are each characterized by its own fauna. The fauna of adjacent beds, however, are so bound together by many common species that there is no palæontologic break. The Mariposa and Knoxville beds are faunally distinct and unconformable; the former Jurassic, and the latter Cretaceous.

Geological sketch of Lower California; by S. F. Emmons and G. P. Merrill. Bull. Geol. Soc. of America, Vol. 5, pp. 489-514, pl. 19. April 21, 1894.

Review of our knowledge on the geology of the California coast ranges; by H. W. Fairbanks. Bull. Geol. Soc. of America, Vol. 6, pp. 71-102. December 24, 1894.

Characteristic features of California gold-quartz veins; by W. Lindgren. Bull. Geol. Soc. of America, Vol. 6, pp. 221-240, pl. 11. March 5, 1895. 


\title{
CALIFORNIA ACADEMY OF SCIENCES.
}

\author{
Published at San Francisco, Cal.
}

Memoirs: Vol. 1, 1868-Vol. 2, 1895.

Bulletins: Vol. 1, 1884-Vol. 2, 1886-87.

Occasional Papers: Nos. 1-4, 1590-95.

Proceedings, 1st series: Vol. 1, 1854-Vol. 7, 1876.

Proceedings, 2d series: Vol. 1, 1838-Vol. 6, 1896.

The natural system of volcanic rocks; by F. Baron Richthofen. Memoirs Cal. Acad. Sci., Vol. 1, Part 2. San Francisco, 1868. 95 pp.

The following is the classification of volcanic rocks:

Order Firs̀t: Rhyolite-

Family 1. Nevadite, or granitic rhyolite.

2. Liparite, or porphyritic rhyolite.

3. Rhyolite proper, or lithoidic and hyaline rbyolite.

Order Second: Trachyte-

Family 1. Sanidin trachyte.

2. Oligoclase trachyte.

Order Third: Propylite-

Family 1. Quartzose propylite.

2. Hornblendic propylite.

3. Augitic propylite.

Order Fourth: Andesite-

Family 1. Hornblendic andesite.

2. Angitic andesite.

Order Fifth : Basalt-

Family 1. Dolerite.

2. Basalt.

3. Leucitophyre.

On certain fossils from San Luis Obispo County; by Dr. Antisell. Proc. Cal. Acad. Sci., Vol. 1, 1854-57, pp. 34-35.

Description of Ammonites Batesi; by Dr. J. B. Trask. Proc. Cal. Acad. Sci., Vol. 1, 1854-57, p. 39.

Descriptions of fossil shells; by Dr. J. B. Trask. Proc. Cal. Acad. Sci., Vol. 1, 1854-57, pp. 40-42.

Chemnitzia papillosa, n.sp.; Tornatella elliptica, n.sp.; Murex fragilis, n.sp.; Fusus Barbarensis, n.sp.; F. robustus, n.sp.; F. rugosus, n.sp.

On the cause of tides, earthquakes, rising of continents, etc.; by Dr. C. F. Winslow. Proc. Cal. Acad. Sci., Vol. 1, 1854-57, pp. $48-51$. 
Remarks on certain geological specimens; by Horace Davis. Proc. Cal. Acad. Sci., Vol. 1, 1854-57, p. 62.

Report on mineral waters from Red Bluff; by Dr. Lanszweert. Proc. Cal. Acad. Sci., Vol. 1, 1854-57, pp. 72-74.

On earthquakes in California from 1812-1857; by Dr. J. B. Trask. Proc. Cal. Acad. Sci., Vol. 1, 1854-57, pp. 85, 102, 109 , and 121.

Republished Am. Jour. Sci, 2d ser., Vol. 22, 1856, pp. 110-116.

Description of new species of Ammonite and Baculite; by Dr. J. B. Trask. Proc. Cal. Acad. Sci., Vol. 1, 1854-57, p. 92.

- Ammonite Chicoensis, n.sp.; Baculite Chicoensis, n.sp.

Description of three new species of the genus Plagiostoma from the Cretaceous rocks of Los Angeles; by Dr. J. B. Trask. Proc. Cal. Acad. Sci., Vol. 1, 1854-57, pp. 93-94, pl. 3.

Plagiostoma Pedroana, n.sp.; P. annulatus, n.sp.; P. truncata, n.sp.

On the mud volcanoes in the Colorado Desert; by Dr. John A.

Veatch. Proc. Cal. Acad. Sci., Vol. 1, 1854-57, pp. 116120.

Republished Am. Jour Sci., 2d ser., Vol. 26, 1858, p. $2 \varepsilon 8$.

The Proceedings of the California Academy of Sciences included in Vol. 1 were originally printed in "The Pacific," a newspaper published in San Francisco. This volume was afterward published by the Academy in two editions.

Earthquakes in California in $1858-59$; by Dr. J. B. Trask. Proc. Cal. Acad. Sci., Vol. 2, 1858-62, pp. 38-39.

Description of two new species of bivalved shell from the Tertiaries of Contra Costa County; by A. Rémond. Proc. Cal. Acad. Sci., Vol. 3, 1863-68, p. 13.

Cardium Gabbi, n.sp.; Ostrea Bourgeoisi, n.sp.

Description of four new species of Echinodermata from the Tertiaries of Contra Costa County; by A. Rémond. Proc. Cal. Acad. Sci., Vol. 3, 1863, pp. 52-53.

Astrodapsis Whitneyi, n.sp.; A. tumidus, n.sp.; Echinarachnius Brewerianus, n.sp.; Clypeaster Gabbi, n.sp. 
Earthquakes in California from 1800-1864; by John B. Trask. Proc. Cal. Acad. Sci., Vol. 3, 1863-68, pp. 130-144.

For articles on same subject, see p. 190; also, p. 239.

Notes on some fossils from the gold-bearing slates of Mariposa, with description of some new species; by W. M. Gabb. Proc. Cal. Acad. Sci., Vol. 3, 1863-68, pp. 172-173.

Lima Erringtoni; Pholadomya orbiculata; Belemnites Pacificus.

Communication on the San Luis Obispo quicksilver fossils; by W. M. Gabb. Proc. Cal. Acad. Sci., Vol. 3, 1863-68, p. 173.

New mineral oil regions in the Tulare Valley; by William P. Blake. Proc.' Cal. Acad. Sci., Vol. 3, 1863-68, p. 193.

Notice of a human skull recently taken from a shaft near Angels, Calaveras County; by J. D. Whitney. Proc. Cal. Acad. Sci., Vol. 3, 1863-68, pp. 277-279.

See also "The Pacific," Vol. XVIII, No. 48; Congregationalist, September 27, 1876, and Rev. des Deux Mondes, Vol. XII, 3d ser., p. 288.

Miscellaneous notices; by William P. Blake. Proc. Cal. Acad. Sci., Vol. 3, 1863-68, pp. 289-291.

1. New locality of fossils, in the gold-bearing rocks of California.

2. Tooth of the extinct elephant, Placer County.

3. Shark teeth and other remains, Tulare County.

4. Quarry of gold-bearing rocks.

This volume contains also other short notices on fossils from Mare Island, Oregon Bar, Mariposa, etc., with mineralogical notices.

On the subdivisions of the Cretaceous formation in California; by W. M. Gabb. . Proc. Cal. Acad. Sci., Vol. 3, 1863-68, pp. 301-306.

On the fresh-water infusorial deposits of the Pacific Coast, and their connection with the volcanic rocks; by J. D. Whitney. Proc. Cal. Acad. Sci., Vol. 3, 1863-68, pp. 319-324.

Notice of new localities of diamonds in California; by B. Silliman. Proc. Cal. Acad. Sci., Vol. 3, 1863-68, pp. 354-357.

Earthquakes on Kern River, in the central portion of the Sierra Nevada; by J. E. Clayton. Proc. Cal. Acad. Sci., Vol. 4, 1868-72, pp. 38-40. 
Remarks on the first discoverer of glaciers in the United States; by George Davidson. Proc. Cal. Acad. Sci., Vol. 4, 18681872, p. 162.

Remarks on surface geology as affected by upheavals; by George Davidson. Proc. Cal. Acad. Sci., Vol. 4, 1868-72, p. 179.

On the coast surface and scenic geology; by Amos Bowman. Proc. Cal. Acad. Sci., Vol. 4, 1868-72, pp. 244-245, with plates.

On some of the ancient glaciers of the Sierras; by Joseph Le Conte. Proc. Cal. Acad. Sci., Vol. 4, 1868-72, pp. 259-262.

Remarks on recent earthquake waves; by George Davidson. Proc. Cal. Acad. Sci., Vol. 4, 1868-72, p. 268.

Notes on the geology of the coast of Oregon; by W. A. Goodyear. Proc. Cal. Acad. Sci., Vol. 4, 1868-72, pp. 295-298.

Remarks on the auriferous gravel deposits in Placer County; by J. M. Wiley. Proc. Cal. Acad. Sci., Vol. 5, 1873-74, pp. 14-16.

The abrasions of the continental shores of Northwest America, and the supposed ancient sea-levels; by George Davidson. Proc. Cal. Acad. Sci., Vol. 5, 1873-74, pp. 90-96.

On the artesian wells of Los Angeles County; by A. W. Chase. Proc. Cal. Acad. Sci., Vol. 5, 1873-74, pp. 104-107.

On the auriferous gravel deposits of California; by George Davidson. Proc. Cal. Acad. Sci., Vol. 5, 1873-74, pp. 145-146.

Notes on the high Sierra south of Mount Whitney; by W. A. Goodyear. Proc. Cal. Acad. Sci., Vol. 5, 1873-74, pp. 180-183.

On the great lava flood of the Northwest, and on the structure and age of the Cascade Mountains; by Joseph Le Conte. Proc. Cal. Acad. Sci., Vol. 5, 1873-74, pp. 214-220. 
On the auriferous sands of Gold Bluff; by Mr. Chase. Proc. Cal. Acad. Sci., Vol. 5, 1873-74, pp. 246-247, with illustrations.

Notes on some Tertiary fossils from the California coast, with a list of the species obtained from a well at San Diego, California, with a description of two new species; by W.H. Dall. Proc. Cal. Acad. Sci., Vol. 5, 1873-74, pp. 296-299.

The new species described are: Chrysodomus Diegoensis, Waldheimia Kennedyi.

Remarks on California coal; by Dr. J. G. Cooper. Proc. Cal. Acad. Sci., Vol. 5, 1873-74, pp. 384-386.

California during the Pliocene epoch; by Dr. J. G. Cooper. Proc. Cal. Acad. Sci., Vol. 5, 1873-74, pp. 389-392.

California in the Miocene epoch; by Dr. J. G. Cooper. Proc. Cal. Acad. Sci., Vol. 5, 1873-74, pp. 401-404.

The Eocene epoch in California: Are there really no Eocene strata? by Dr. J. G. Cooper. Proc. Cal. Acad. Sci., Vol. $5,1873-74$, pp. 419-421.

Note on the Tertiary formation of California; by Dr. J. G. Cooper. Proc. Cal. Acad. Sci., Vol. 5, 1873-74, p. 422.

Cinder cone age of eruption; by H. A. Harkness. Proc. Cal. Acad. Sci., Vol. 5, 1874, p. 408.

On some of the ancient glaciers of the Sierra; by Joseph Le Conte. Proc. Cal. Acad. Sci., Vol. 6, 1875, pp. 38-48, with plate.

The glacial period, its origin and development; by J. E. Clay-, ton. Proc. Cal. Acad. Sci., Vol. 6, 1875, pp. 123-131.

On the result of the glacial action at the head of Johinson's Pass in the Sierras; by James Blake. Proc. Cal. Acad. Sci., Vol. 6, 1875, pp. 170-175.

There were no geological reports in Vol. 7 of the Proceedings of the California Academy of Sciences, published in 1876. 
IVest Coast Pulmonata: fossil and living; by Dr. J. G. Cooper. Proc. Cal. Acad. Sci., 2d ser., Vol. 1, 1888, pp. 11-24. (Continued from Bulletin No. 8, p. 514.)

Notes on the geology of Baja California, Mexico; by W. Lindgren, U. S. Geological Survey. Proc. Cal. Acad. Sci., 2d ser., Vol. 1, 1888, pp. 173-196, with 5 plates.

Description of Pleistocene, Tertiary, Cretaceous, Eruptive, basal granites, and structural features. The author gives a geological profile from San Diego to the Colorado Desert, pl. III.

There were no geological reports in Vol. 2, second series, of the Proceedings of the California Academy of Sciences, published in 1889.

An illustration of the flexure of rock; by George H. Ashley. Proc. Cal. Acad. Sci., 2 d ser., Vol. 3, 1890-92, pp. 319324.

Geological surveys in the State of California; by Anthony W. Vogdes. Proc. Cal. Acad. Sci., 2 d ser., Vol. 3, 1890-92, pp. 325-337.

On the discovery of Proetus ellipticus, Meek, in the Carboniferous limestone of Shasta County; by A. W. Vogdes. Proc. Cal. Acad. Sci., 2d ser., Vol. 3, 1890-92, p. 376.

On some Pliocene fresh-water fossils of California; by Dr. J. G.

Cooper. Proc. Cal. Acad. Sci., 2 d ser., Vol. 4, 1894, pp. 166-172, Pl. XIV.

Margaritana subangulata, n.sp.

The Neocene stratigraphy of the Santa Cruz Mountains of California; by George H. Ashley. Proc. Cal. Acad. Sci., 2d ser., Vol. 5, 1895, pp. 273-365, Pls. XXII-XXV.

On fossil and sub-fossil land shells of the United States, with notes on living species; by Dr. J. G. Cooper. Bull. Cal. Ácad. Sci., No. 4, 1886, p. 235 ; No. 7, 1887, p. 355 ; No. 8, 1887, p. 497.

The Washoe rocks; by George F. Becker. Bull. Cal. Acad. Sci., No. 6, 1887, pp. 93-120.

See also American Naturalist, Vol. 22, 1888, pp. 639-640. 


\section{FOREIGN SOCIETIES.}

Origin of continents; by W. O. Crosby. Geol. Mag., Vol. 10, June, 1883, pp. 241-252.

Lower Californian eruptive rocks; by E. Ritter. Arch. des Sci., Vol. 33,1895, p. 330.

Đie Californischen Bacillarien-Gebirge; by J. D. Whitney. Monatsber. K. preuss. Akad. Wiss., Berlin, 1872, pp. 124-139.

Zwei profile durch die Sierra Nevada; von E. Reger. Neues jahrbuch IV, Beilage Band 1886, pp. 291-326, plates XVII, with 24 illustrations.

Ueber die wachsende kenntniss des unsichtbaren Lebens als felsbildende Bacillarien in Californien; von Ehrenberg. Berlin Akad. Abhandl., 1870, pp. 126-132; Berlin Monatsber. Akad., 1870, pp. 259-264.

On the gold regions of California; by J. S. Wilson. Jour. Geol. Soc. of London, Vol. 10, 1854, pp. 308-321.

The author gives a geological sketch-map of part of Upper California, comprising the southern mines; section across, Upper California from the Pacific to the Sierra Nevada, length 70 miles; Fig. 3, section of auriferous detritus at Sullivan's Gulch; Fig. 4, section of quartz vein in Carson's Hill; Fig. 5, section at Murphy's Deep 1)iggings.

A contribution to the history of mineral veins; by J. Arthur Phillips. Jour. Geol. Soc. of London, Vol. 35, 1879, pp. 390-396.

On the hot springs of California.

Geologie-Observations sur les gesements auriferes de la Californie; par M. L. Simonin. Comptes Rendus de l'Académie des Sciences, 20 Février, 1860. t. 50, p. 389. Paris.

Sur l'action des anciens glaciers dans la Sierra Nevada de Californie et sur l'origine de la vallée de Yo Semite; par W. P. Blake. Comptes Rendus, Paris, 22 July, 1867. $3 \mathrm{pp}$. 
On the geographical distribution and physical characteristics of the coal fields of the North Pacific Coast; by Robert Brown. Trans. Edinburgh Geol. Soc., 1868-69. 23 pp.

Contains Tertiary coals of the North Pacific: 1. Monte Diablo, California; 2. Coos Bay, Oregon; with analysis of native and imported coals.

Note sur le géologie de la Californie; par Jules Marcou. Bull. • Soc. Geol. of France, 1883, pp. 407-435; with geological map of California.

Catalogue of recorded earthquakes from 1606 B. C. to A. D. 1850; by Robert Mallet. Report British Assoc. Adv. Sci., 1854.

Report on the present state of our knowledge with regard to the mollusca of the west coast of North America; by Philip P. Carpenter. Report British Assoc. Adv. of Science, 1856, pp. 159-368.

Supplementary report on the present state of our knowledge with regard to the mollusca of the west coast of North America; by Philip P. Carpenter. Report British Assoc. Adv. of Science, 1864, pp. 517-686.

See also Smithsonian Miscellaneous Collections No. 252. Washington, 1872.

Untersuchungen in Californien; von Jules Marcou. Verhandl. d. K. K. Geol. Reichsanstalt, 1875, pp. 215-216, No: 12.

Sur le gisement de l'or en Californie; par Jules Marcou. Bibliothèque Universalle de Genève, Février, 1854. Genève.

Mikroskopische beobachtungen an Californischen gesteinen; von M. Schuster. Neues Jahrb. 1887, V. Beil. Bd. ss. 451578, tafel 17-20. (Abstract from American Naturalist, Vol. 22, 1887, p. 452.)

Detailed description of the micro-petrography of eighty rock specimens from the Sierra Nevada, and a discussion of the mineralogic constituents.

Mittheilungen über die Geologie Californiens; von Jules Marcou. Neues Jahrbuch für Mineralogie, Geologie, und Palæontologie, Jahrgang 1883, Bd. II, pp. 52-58. 
Beitrag zur Kenntniss der geognostischen Beschaffenheit Californiens; von Dr. G. Grewingk. Verhandlungen der Russisch-Kaiserlichen Mineralogischen-Gesellschaft. zu St. Petersburg. Jahr. 1847, pp. 142-162.

FRANKLIN INSTITUTE JOURNAL AND AMERICAN MECHANICS' MAGAZINE.

Published at Philadelphia.

Experiments on various coals of the Carboniferous and Cretaceous periods, to ascertain their relative potential and economic vaporizations; made by Chief Engineer B. F. Isherwood, U. S. Navy, at the Mare Island Navy Yard, California, in 1871. Journal of Franklin Institute, Vol. 27, 3d ser., No. 6, June, 1872, pp. 392-402.

See Report U. S. Navy Department. House Doc. $42 d$ Cong., $2 d$ session, Ex. Doc. 206, 1872.

\section{HUTCHINGS'S ILLUSTRATED CALIFORNIA MAGAZINE.}

A mammoth tusk. Hutchings's Illustrated California Magazine, Vol. 2, 1857-58, pp. 15-16.

\section{HUN'T'S MERCHAN'TS' MAGAZINE.}

A history of the discovery of gold in California; by Geo. M. Evans. Hunt's Merchants' Magazine, Vol. 31, p. 385.

\section{JOURNAL OF GEOLOGY.}

Published at Chicago, Ill.

Vol. 1, 1893-Vol. 3, 1895.

Revolution in the topography of the Pacific Coast since the Auriferous period; by J. S. Diller. Jour. Geol., Vol. 2, 1894, pp. 32-54. 
The Arkansas coal measures in their relation, to the Pacific Carboniferous province; by James Perrin Smith. Jour. Geol., Vol. 2, No. 2, February-March, 1894.

The author refers to the Pacific Carboniferous sea under the following headings: Revolution in Devonian time; the Carboniferous sea; Upper Carboniferous in the West; the Pawhuski limestone; interchange of life between East and West; replacement of limestone by the coal-bearing formation in Western Europe; land areas in the West; the Permian Pacific Ocean; Triassic Pacific Ocean.

The Metamorphic Series of Shasta County, California; by James Perrin Smith. Jour. Geol.,-Vol. 2, No. 6, September-October, 1894.

The author, under "Stratigraphy," gives the following general heading to his article:

Columnar section of the metamorphic series: Sacramento formation-Kennett limestones and shales. McCloud formation-occurrence and character. Baird shales-distribution and fossils; affinities of the fauna. McCloud limestone-occurrence and character; fauna of the McCloud limestone. Pitt formation-general character of the rocks ; the Carboniferous argillites; the Triassic shales and conglomerates. Cedar formation-distribution and character; Swearinger slates; Hosselkus limestone; Atractites beds; Spiriferina beds; etc. Bend formation-Jura-Trias uncomformity.

Mesozoic changes in the faunal geography of California; by J. P. Smith. Jour. Geol., Vol. 3, No. 4, 1895, pp. 369-384.

The age and succession of the igneous rocks of the Sierra Nevada; by W. H. Turner. Jour. Geol., Vol. 3, No. 4, 1895, pp. 385-414.

The stratigraphy of the California coast ranges; by H. W. Fairbanks. Jour. Geol., Vol. 3, No. 4, 1895, pp. 415-433.

Studies in the Miocene of California; by Geo. H. Ashley. Jour. Geol., Vol. 3, No. 4, 1895, pp. 434-454.

\section{THE MINING MAGAZINE.}

\section{Published at New York.}

Geology of the Sierra Nevada, or California, range; by Prof. John B. Trask. Mining Mag., Vol. 1, 1853, pp. 6-23. 
Mineral distriets of Central California; by Prof. John B. Trask. Mining Mag., Vol. 3, 1854, pp. 121-136; continued on pp. 239-250.

Geology of the gold region of California; by Mr. Wilson. Mining Mag., Vol. 3, 1854, pp. 63-64.

Observations on the extent of the gold region of California and Oregon; by William P. Blake. Mining Mag., Vol. 5, 1855 , pp. 32-45.

\section{MINING AND SCIEN'TIFIC PRESS.}

Published at San Francisco.

Earthquakes in San Francisco, and specially on their direction; by J.'A. Veatch. Mining and Scientific Press, March 31,1868 .

Cinnabar at Point Reyes. Mining and Scientific Press, February 27,1875 .

See also Vol. 27, 1873, p. 166; Vol. 29, Aug. 15, 1874; Vol. 31,1875 , p. 118 , for articles and references to the Cinnabar of California.

\section{NATURE.}

Prairie mounds of California and Oregon; by Joseph Le Conte. Nature, Vol. 15, 1877, p. 530.

\section{NEW YORK ACADEMY OF SCIENCES.}

Silicified wood from California; by James J. Friedrich. Trans.

New York Acad. Sci., Vol. 8, 1889, pp. 29-30.

Includes reference to the relations and age of the associated deposits in Lake and Napa Counties. 


\section{OVERLAND MONTHLY.}

Published at San Francisco, Cal.

On actual glaciers in California; by John Muir. Overland Monthly, December, 1872.

On the earthquake of March 26,1872 ; by J. D. Whitney. Overland Monthly, Vol. 9, 1872.

On mountain sculpture in the Sierra Nevada, and the method of glacial erosion; by E. S. Carr. Overland Monthly, Nay, 1874.

\section{PHARMACEUTICAL JOURNAL.}

Report on the geology of the Sierra Nevada, or' Californian, range; by John B. Trask. Pharmaceutical Journal, Vol. 14, 1855, pp. 20-24.

\section{PHILOSOPHICAL SOCIETY OF WASHINGTON.}

Bulletins: $1880-1895$.

Notes on the faults of the Great Basin and of the eastern base of the Sierra Nevada; by J. C. Russell. Washington Philos. Soc. Bull., Vol. 9, 1887, pp. 5-6.

See also Neuer Jahrb., Band 2, 188\%, pp. 317-318.

Notes on the geology of Northern California; by J. S. Diller. Washington Philos. Soc. Bull., Vol. 9, 1887, pp. 4-5; additional note on p. 8 .

See Am. Jour. Sci. and Arts, 3d ser., Vol. 33, 1887, pp. 152-153; Am. Geologist, Vol. 1, 1888, pp. 125-126; and Popular Sci. Monthly, Vol. 32, 188.8, p. 419.

This paper is an abstract of Bull. U. S. Geol. Sur, No. 33.

Stages of geologic history of Sierra Nevada; by G. K. Gilbert. Washington Philos. Soc. Bull., Vol. 9, 1887, p. 7.

Remarks following paper, by J.S. Diller, on geology of Northern California. 


\section{NEWPORT NATURAL HISTORY SOCIETY.}

A sketch of the geological development of the Pacific Slope; by Geo. F. Becker. Proceedings Newport Natural History Society, 1886-87, Document 5. Newport, 1887. pp. 1-12.

\section{PHILADELPHIA ACADEMY OF NATURAL SCIENCES.}

Journal, 1st series: Vol. 1, 1817-Vol. 8, 1842.

Journal, 2d series: Vol. 1, 1847-Vol. 10, 1895.

Proceedings, 1st series: Vol. 1, 1841-Vol. 8, 1856.

Proceedings, 2d series: Vol. 1, 1857-Vol. 14, 1870.

Proceedings, 3d series: Vol. 1, 1871-Vol. 24, 1894.

Descriptions of new marine shells from Upper California, collected by Thomas Nuttall, Esq.; by T. A. Conrad. Journal Phila. Acad. Nat. Sci., 1st ser., Vol. 7, 1837, pp. 227-268, pl. 17-20.

Several of the species appear in the Tertiary formation of California. A list can be found in Dr. Cooper's catalogues.

Notes on the Miocene and Post Pliocene deposits of California, with descriptions of two new fossil corals; by T. A. Conrad. Proc. Phila. Acad. Nat. Sci., Vol. 7, 1855, p. 441.

Ostrea Titan; Pandora bilirata; Cardita occidentalis; Diadora crucibuliformis.

These fossils were afterward described and figured in Pacific Railroad Reports, Vol. VI, 1857.

Descriptions of three new genera and twenty-three new species of Middle Tertiary fossils from California and one from Texas; by T. A. Conrad. Proc. Phila. Acad. Nat. Sci., Vol. 8, 1856, pp. 312-316.

Schizopyga Californiana; Cryptomya ovalis; Thracia mactropsis; Mya Montereyana; M. subsinuata; Arcopagia medialis; Tapes linteatumo; Arca canalis; A. trileneata; A. congesta; Axincea Barbarensis; Mulinia densata; Dosinia longula; D. alta; Pecten Pabloensis; Pallium Estrellanum; Janira bella.

These fossils were afterward described and figured in Pacific Railroad Reports, Vol. VI, 1857, pp. 69-73. 
Descriptions of new Cretaceous fossils collected by the Northwestern Boundary Commission on Vancouver's and Sucia Islands; by F. B. Meek. Proc. Phila. Acad. Nat. Sci., 2d ser., Vol. 5, 1861, pp. 314-318.

See also Bull. U. S. Geol. Sur. of the Territories, Vol. 2, 1876.

Descriptions of new species of American Tertiary fossils and a new Carboniferous Cephalopod from Texas; by W. M. Gabb. Proc. Phila. Acad. Nat. Sci., 1861, pp. 367-372.

The following California species are described in this paper:

Turbonilla aspera, n.sp., Miocene, from Santa Barbara.

Modelia striata, n.sp., Miocene, from Santa Barbara.

Sphenia bilirata, n.sp., Miocene, from Santa Barbara.

Venus rhysomia, n.sp., Miocene, from Santa Barbara.

Cardita monilicosta, n.sp., Miocene, from Santa Barbara.

Morrissia Horni, n.sp., Miocene, from Santa Barbara.

Indication of an Elotherium in California; by Joseph Leidy. Proc. Phila. Acad. Nat. Sci., 1868, p. 177.

Elotherium superbus, n.sp., from Calaveras County.

On mastodon remains; by Joseph Leidy. Proc. Phila. Acad. Nat. Sci., 1870, pp. 96-97.

On a mastodon discovered in Contra Costa, California.

Vertebrate fossils from, auriferous gravels; by Joseph Leidy. Proc. Phila. Acad. Nat. Sci., 1870, p. 125.

On an extinct whale from California; by E. D. Cope. Proc. Phila. Acad. Nat. Sci., 1871, pp. 29-30.

Remarks on extinct mammals from California; by Joseph Leidy. Proc. Phila. Acad. Nat. Sci., 1872, p. 259.

Extract of a letter relating to mammalian fossils in California; by Dr. L. G. Yates. Proc. Phila. Acad. Nat. Sci., 1874, pp. 18-21.

This paper gives a list of localities-fossil elephas, and fossil mastodon.

The blue gravel of California; by E. Goldsmith. Proc. Phila. Acad. Nat. Sci., 1874, pp. 73-74.

Descriptions of new fossil shells from the Tertiary of California; by R. E. C. Stearns. Proc. Phila. Acad. Nat. Sci., 1875, pp. 463-464, pl. 27.

Opalia varicostata, n.sp.; O. anomala, n.sp. 
Note on a Cerripede of the California Miocene, with remarks on fossil shell; by R. E. C. Stearns. Proc. Phila. Acad. Nat. Sci., 1876, pp. 273-275.

The author refers Tamiosma gregaria, Conrad, to the genus Balanus.

On the occurrence of Ammonites in deposits of the Tertiary age; by A. Heilprin. Proc. Phila. Acad. Nat. Sci., 1882, p. 94 .

On the age of the Tejon rocks of California and the occurrence of Ammonitic remains in Tertiary deposits; by A. Heilprin. Proc. Phila. Acad. Nat. Sci., Vol. 34, 1882, pp. 196-214.

The author remarks (p. 213) that the rocks of the Tejon group (Cretaceous, Div. B, of the California Survey), despite their comprising, in their contained faunas, a limited number of forms from the subjacent (Cretaceous) deposits, and a few undoubted representatives of the Ammonitidx, are of Tertiary (Eocene) age.

The Eocene age of the Tejon rocks is also maintained by Prof. Jules Marcou, who made a personal examination of the region. (Rept. Chief Engineers, 1876, p. 387.)

On supposed Tertiary Ammonites; by J. S. Newberry. Proc. Phila. Acad. Nat. Sci., 1882, pp. 194-195.

Age of Tejon rocks of California and the occurrence of Ammonitic remains in Tertiary deposits; by A. Heilprin. Proc. Phila. Acad. Sci., 1890, pp. 445-489.

Extinct mammalian fauna of Dakota and Nebraska, including an account of some allied forms from other localities; by J. Leidy. Jour. Phila. Acad. Nat. Sci., Vol. 7, 1869.

\section{PUBLICATIONS OF U. S. NATIONAL MUSEUM.}

Post Pliocene fossils in the Coast Range of California; by W. H. Dall. Proc. U. S. Natl. Mus., Vol. 1, 1878, p. 3.

Specimens of Donax Californicus, Chione succincta, Olivella biplicata, and Certhidea sacrata in a semi-fossilized condition from San Luis Rey, Cal. 
Fossil mollusca from later Tertiary of California; by W. H. Dall. Proc. U. S. Natl. Mus., Vol. 1, 1878, pp. 10-16.

The author gives a table of one hundred and seven species, ten of which are extinct and ninety-seven still found recent, with a description of the following new species: Axinea profunda, Pecten expansus, P. Stearnsi, P. Hemphilli, Anomia limatula, Socalaria Hemphilli.

Distribution of Californian Tertiary fossils; by W. H. Dall. Proc. U. S. Natl. Mus., Vol. 1, 1878, pp. 26-30.

The author notes those of the strata of the San Diego Peninsula and those of the mainland, near the town of San Diego, etc.

Jurassic or Cretaceous beds appear to exist at Todos Santos Bay, Lower California, not far from San Diego.

Note on the occurrence of Productus giganteus in California; by C. A. White. Proc. U. S. Natl. Mus., Vol. 3, 1880, pp. 46-47, pl. 1.

From the Carboniferous of McCloud River, Shasta County, California.

Directions for collecting and preparing fossils; by Charles Schuchert. Bull. U. S. Natl. Mus., No. 39. Washington, 1895.

Contains California localities of fossils.

\section{SANTA BARBARA SOCIETY OF NATURAL HISTORY.}

Infusorial earth at Santa Barbara, California; by W. W. Finch. Santa Barbara Soc. Nat. Hist., Bull. No. 1, 1887, pp. 8-11.

\section{ST. LOUIS ACADEMY OF SCIENCES.}

Descriptions of new fossils from the Tertiary formation of Oregon and Washington Territories, and the Cretaceous of Vancouver's Island, collected by Dr. John Evans, U. S. Geologist, under instructions from the Department of the 
Interior; by B. F. Shumard. Trans. St. Louis Acad. Sci., Vol. 1, 1858, pp. 120-125.

These fossils were obtained from Port Orford, Willamette Valley, Coos Bay, and Vancouver's Island. The following are described but not figured: Lucina fibrosa, n.sp.; Corbula Evansana, n.sp.; Leda Willamettensis, n.sp.; L. Oregona, n.sp.; Pecten Coosensis, n.sp.; Venus securis, n.sp. From the Cretaceous of Vancouver's Island: Inoceramus Vancouverensis, n.sp.; Pinna calamitoides, n.sp.; and Pyrula glabra, n.sp.

\section{SCIENCE.}

Sierra structure; by G. K. Gilbert. Science, March 23, 1883, p. 195.

Coal in the Chico group of California; by J.S. Diller. Science, Vol. 5, 1885, p. 43.

This announcement shows that the Chico group, like its equivalent, the Nanaimo group, is a coal-bearing bed.

The author states that a number of fossils were collected from the coal-bearing strata in Northern California, eight miles northeast of Yreka, on the road to Linkville, Oregon. He does not give a list, which is given in Dr. White's report on the Chico group.

The latest volcanic eruption in the United States; by C. E. Dutton. Science, Vol. 6, 1885, p. 46.

Agriculture and late Quaternary geology; by E. W. Hilgard. Science, Vol. 11, 1888, pp. 241-242.

Descriptions of evidence of an ancient drainage system in the Upper San Joaquin Valley, California.

North American Mesozoic; by Charles A. White. Science, Vol. 14, 1889, pp. 160-166.

Correlations of Tejon deposits with Atlantic stages of the Gulf slope; by G. D. Harris. Science, Vol. 22, 1893, p. 97.

Petroleum in Southern California ; by S. F. Peckham. Science, Vol. 23, 1894, pp. 74-78. 


\title{
SCHOOL OF MINES QUARTERLY.
}

The genesis and distribution of gold; by J. S. Newberry. School of Mines Quarterly, Nov., 1881.

Notes on the dry lakes of Southern Nevada and California, with relation to the Lœss; by Walter P. Jenney. School of Mines Quarterly, Vol. 10, 1889, pp. 316-318.

Description of the lakes, their deposits and history.

\section{WEST AMERICAN SCIEN'TIST.}

\author{
Published at San Diego, Cal. \\ (C. R. Orcutt, Editor.)
}

New Cretaceous fossils. West American Scientist, Vol. 3, pp. 28-31.

Trochus (Oxystele) euryostomus, White; Cerithium Pillingsi, White ; C. totium sanctorum, White; Solarium Wallalensis, White; Nerita Californiensis, White.

All these fossils were described in U. S. Geol. Sur. Bull. No. 22, 1885, except Nerita Californiensis.

Minerals and mines of San Diego; by C. R. Orcutt. West American Scientist, Vol. 3, p. 69.

Gypsum on the coast of Lower California; by M. Lopateck. West American Scientist, Vol. 3, p. 117.

Fossil botany; by Dr. L. G. Yates. West American Scientist, Vol. 3, p. 180.

Fossil botany, No. 2 ; by Dr. L. G. Yates. West American Scientist, Vol. 3, p. 201.

Fossil botany, No. 3; by Dr. L. G. Yates. West American Scientist, Vol. 3, p. 213.

Fossil botany, No. 4; by Dr. L. G. Yates. West American Scientist, Vol. 4, p. 20. 
Fossil botany, No. 5 ; by Dr. L. G. Yates. West American Scientist, Vol. 5, p. 39.

Fossil ferns; by O. D. Walbridge. West American Scientist, Vol. 3, p. 217.

A study of river geology; by W. R. Lighton. West American Scientist, Vol. 4, p. 24.

The gold fields of Lower California; by C. R. Orcutt. West American Scientist, Vol. 6, p. 4.

Some notes on Tertiary fossils of California; by C. R. Orcutt. West American Scientist, Vol. 6, p. 70.

Gives list of fossils at Pacific Beach, San Diego.

Some notes on Tertiary fossils of California; by C. R. Orcutt. West American Scientist, Vol. 6, p. 84 .

List of fossils in a San Diego well.

The California geysers; by Joseph Keep. West American Scientist, Vol. 6, p. 99.

\section{TRANSACTIONS ALBANY INSTITUTE.}

Description of new organic remains from the Cretaceous rocks of Vancouver's Island; by F. B. Meek. Trans. Albany Inst., Vol. 4, 1857, pp. 37-49. See also Bull. U. S. Geol. Sur., Vol. 2, No. 4, 1876.

Gabb, in the Palæontology of California, refers to the following species in this article: Pholadomya subelongata, Meek; Ammonites (Scaphites?) ramosus, Meek; A. Newberryanus, Meek; Baculites ovatus, Say?, for which Meek suggests the name of $B$. occidentalis.

\section{TRANSACTIONS AMERICAN INSTITUTE OF MINING ENGINEERS.}

\section{Published at New York City.}

The production of gold and silver in the United States; by $R$. W. Raymond. Trans. Amer. Inst. Mining Engineers, Vol. 3, p. 202; see also Vol. 5, p. 175. 
Mercury associated with bitumen; by T. Egleston. Trans. Amer. Inst. Mining Engineers, Vol. 3, p. 273.

Geology of American Valley. Trans. Am. Inst. Mining Engineers, Vol. 13; p. 217.

The silver mines of Calico, California; by W. Lindgren. Trans. Amer. Inst. Mining Engineers, Vol. 15, p. 717-734.

Description and sections of the region, and discussion of the lithological, stratigraphic, and structural features of the Tertiary sandstones, tuff deposits, liparite, and andesite, and their relations to the ore deposits.

Hydraulic mining in California; by A. J. Bowie, Jr. Trans. Amer. Inst. Mining Engineers, Vol. 6, 1879, p. 27.

Contains map of river tunnel on Mariposa Estate.

Mining developments on the northwestern Pacific Coast, and their wider bearing; by Amos Bowman. Trans. Amer. Inst. Mining Engineers, Vol. 15, 1887, pp. 707-717.

\section{ZOE}

Published at San Francisco, Cal.

On the discovery of Proetus ellipticus, Meek, in Shasta County, California, which is referred to the Waverly group; by A. W. Vogdes. Zoe, Proceedings of Societies, Vol. 3, 1892, p. 274.

Notes on the geology of the Farallones; by J. W. Blankinship. Zoe, Vol. 3, 1892, pp. 145-146. 


\section{PART IV.}

\section{Publications of State Geological Surveys other than that of California.}

\section{MISSOURI GEOLOGICAL SURVEY.}

\section{(Volume VI.)}

Lead and zinc deposits; by Arthur Winslow, assisted by James D. Robertson. Jefferson City, 1894. 2 vols.

On page 187 the author states that although California is not classed as a lead-and zinc-producing State, it contains extensive deposits of lead-producing ores. These occur principally in Inyo and San Bernardino Counties, in the southwestern portion of the State. He gives the localities of the lead deposits of San Bernardino County, near Kingston Mountain, in dolomitic limestone; near Denby, in the Old Woman Mountains. He mentions a large and extensive ledge of carbonate and galena in granite and slate formations. Other localities are mentioned, both in Inyo and San Bernardino Counties, on the authority of the Ninth Annual Report of the State Mineralogist; 10th and 11th Census Reports. 


\section{PART V.}

\section{Miscellaneous Publications.}

(Alphabetical List.)

Aaron, C. H. Practical treatise on testing and working silver ore. San Francisco, 1876. 114 pp.

- Assaying. In three parts; in two volumes. San Francisco, 1885.

_ Leaching gold and silver ores. San Francisco, 1880.

Aimard, Gustave. The goldseekers. Philadelphia, 1863. $12 \mathrm{mo}$.

Allen, W. W., and Avery, R. B. California gold book. First nugget; its discovery and discoverers, and some of the results proceeding therefrom. San Francisco and Chicago, 1893. $439 \mathrm{pp}$.

There are some geological notes given in Chapter XII, under the heading of Gold.

Allsopp, Robert. California and its gold mines. Being a series of recent communications from the mining district upon the present condition and future prospects of quartz mining. London, $1853.149 \mathrm{pp}$.

This work contains a letter on the advantages of California, and also an article entitled, Why quartz companies are failures.

Anderson, Alexander D. The silver and gold of the Southwest: St. Louis, 1877.

Anderson, C. L. The natural history of Santa Cruz County, comprised in chapters on Geology, Marine and Land Botany, Fishes and Birds, for the use of students of all ages, in or out of schools, and the public generally. Oakland, 1894. $67 \mathrm{pp}$. 
Andersox, Winslow. Mineral springs and health resorts of California, with a complete chemical analysis of every important mineral water in the world. San Francisco, 1890. 384 pp. illustrated.

This book contains brief geological descriptions on the formation of mineral springs, causes of subterranean heat, with notes on the mineral springs of the Coast Range, etc.

Ansted, David Thomas. The goldseeker's manual. London, 1849. $96 \mathrm{pp}$.

Ashburner, William. Report of California Water Company. 1880. San Francisco, 1880.

Contains report upon the property of the California Water Company, by W. Ashburner; with report on gold mines, by E. P. Hutchins, and report of Amos Bowman.

Report of the Sulphur Bank Quicksilver Mining Company, Lake County, California. 1876.

Contains reports by William Ashburner, James D. Hague, Thomas Price, and M. C. Vincent. A general description of Clear Lake region is given on page 5 .

- Report upon Approach Gold Quartz mine. San Francisco, 1866.

AtTwood, Melville. On the milling of gold quartz-amalgamation. In Mining and Scientific Press, August 20, 1881. tract of 5 pages.

Paper on the microscopical examination of rocks. San Francisco, 1888,

BARRY, John D. Report on the proposed Eocene tunnel at Big Bend, on the North Fork of the Feather River, Butte County, California.

Contains map and section of rocks.

Becker, George F. The structure of a portion of the Sierra Nevada in California. 1891. tract.

BeEchey, Capt. F. W. Narrative of a voyage to the Pacific and Behring's Strait, to coöperate with the Polar expedition 
performed in his Majesty's ship Blossom, under the command of Capt. F. W. Beechey. London, 1831. 2 vols.

In the volume on the zoölogy of Captain Beechey's voyage (London, 1839, 4to), by Prof. Buckland, there are several references to the geology of the vicinity of San Francisco, prepared from the notes and collections of Lieutenant Belcher.

A map of the headland, embracing San Francisco Bay, accompanies this report. This is colored around the shores so as to indicate the several formations; serpentine, sandstone, and jasper rock are represented. Lieutenant Belche̊r collected specimens of serpentine on the west side of Angel Island. The occurrence of jasper rock is also noted.

The author, on page 174, gives the following account of the geology of California, which was the first ever published; it is given in full, on account of its value :

GEOLOGY, BAY OF SAN FRANCISCO.

"The specimens collected in and near the Bay of San Francisco consist of many varieties of common serpentine, bronzite, and asbestos; clay-slate and mica slate, chlorite slate, horn-stone, brown, green, and red jasper, and rolled blocks of glassy actynolite; grey sandstone, and imperfect wood-coal. The country near the port of San Francisco is con posed chiefly of sandstone, jasper, and serpentine. Woodcoal is found in slight seams on the north side of the entrance of the bay, and native salt near Santa Clara. Many of the summits of the hills are composed of jasper, forming enlongated ridges, of which the general direction is north and south. This jasper is succeeded by sandstone, of a loose texture, not effervescing with acids, and disposed in every angle of stratification, occasionally it is hard and of a blue cast; it is frequently interrupted by abrupt masses of laminated jasper in wavy stratification. The appearance of the jasper, at its contact with the sandstone, is often very remarkable. The jasper appears not to have acted on or displaced the sandstone; its exterior, for eighteen inches or two feet, is usually rugged, and mixed with carbonate of lime, quartz, and indurated clay; its interior, however, presents a very beautiful wavy disposition of the component laminæ, a remarkable example of which occurs at the Needle Rock, nearly opposite the fort. A view of it is engraved at Pl. III, Geology. It resembles an immense mass of sheets of paper, or bands of list, crumpled and contorted by lateral pressure. This contortion only occurs in the red jasper, the yellow being seldom (if at all) stratified, but generally separated by cracks into rhomboidal pieces. A mass of at least one hundred feet in thickness is beautifully stratified in short, wavy lines, oppositc the fort near Punta Diavolo, and rests on sandstone.

"Between Punta Boneta and Punta Diavolo the sandstone is of a bluish-grey colour, containing particles of coal.

"The Island of Los Angelos is of very confused formation. Its eastern side is sandstone, with occasional jasper rocks; its western side exhibits sandstone, conglomerate, clay-slate, and serpentine; its south side, bluish earth, (apparently decomposed serpentine), and jasper beds containing red siliceous nodules, and much iron pyrites. 
The superstratum of this island is almost entirely composed of the débris of sandstone and jasper rocks, a little slate and bluish earth, and betrays appearances of violence. It is about 900 feet above the level of the sea.-B.

"The cliffs of the main land, opposite the northwest shore of the Island of Los Angelos afford masses of actynolite and beds of mica slate and talc slate.

"The Island of Molate, about four miles north of Los Angelos, appears at a distance to be of a red colour, and contains much red jasper, and in a small portion of the cliff black ferruginous slate.-C.

"In the Island of Yerba Buena, the perpendicular cliffs west of the bay are formed of clay-slate at their base, whilst the superincuhbent rock is sandstone, for the most part in angular masses, and without distinct stratification. The clay-slate is much contorted, arched, and wavy, assuming an east and west direction, and dipping chiefly to the south at a considerable angle. The sandstone shows itself in the point that forms the'eastern part of the bay.

"The rounded hills of the peninsula on which the Presidio of San Francisco is placed, are variously formed of sandstone, loose sand, serpentine, flinty slate, and jasper. The westernmost hill, which rises from the sea between the fort and the Punta di los Lobos, is serpentine. The north declivity, on which the quadrangle of the Presidio is built, is sandstone. To the eastward of this the serpentine again forms a hill of equal if not greater height. The hill to the westward of the Mission is serpentine. That which rises to the south of it exposes a bare and scarped brow of flinty slate and jasper. Rocks of a similar nature protrude through the surface of the soil of the hills which separate San Francisco from the extensive valley of Santa Clara (Las Salinas), about six leagues to the southward. These hills are called Sierras di los Samburnos, and terminate on the north in a rocky prominence, in the harbour east of the inlet of the Mission.

"The range of mountains, Las Sierras del Sur, which bound the above valley to the south, expose flinty slate approaching to jasper, a little northwest of Las Pulgas, and about eighteen miles east-southeast of the Mission of San Francisco. Between the Missions of Santa Clara and Santa Cruz, these mountains form four parallel ranges, the two middle ones highest (about 1,500 feet), with steep declivities; the first two valleys are narrow; the third is more extensive, leading to the fourth range, which is considerably lower than the others. The first two ridges are composed of serpentine and a jaspery rock, the third principally of sandstone and occasionally jasper, and the fourth, that nearest Santa Cruz, entirely of sandstone, the upper part being mostly decomposed into loose sand. Petrified bones of a cylindrical form were found in this cliff of sand or loose sandstone in 1827.

"Where this range approaches the road from Santa Clara to San Juan, nearly half-way, the northern declivity is covered with fragments of serpentine, and a little farther on is sandstone and flinty slate.

"In the neighbourhood of the Mission of San Juan is a sandstone conglomerate, and on the road crossing from San Juan to the plain of Monterey, is sandstone. From the interior of the range between San Juan and Monterey, the inhabitants of Las Animas had brought compact basalt, containing particles of magnetic iron ore, which 
encouraged the delusive hope of rich mines. $A$ few miles down the river Paxaros, from where the road to San Juan crosses it, there are thermal springs, and sulphur in their neighbourhood. On the Santa Cruz side, near the Mission, there is said to be coal, but it has never been mined. Along the east shore of the Bay of San Francisco, for thirty-five miles east-southeast, from beyond the Island of Molate, towards San Josef and Santa Clara, the harbour is bounded generally by low alluvial soil, and only in a few places do low and rocky cliffs protrude. Near the Mission of San Josef there are some hot springs in the plain, surrounded by a verdant covering. Larthquakes are rather common, and one in 1806 so shook the building of the Mission of Santa Clara, that a new one was obliged to be erected. A few years ago, a boat belonging to a whale ship, when lying in several feet water, was suddenly thrown on the beach and left dry, and a vessel in the Bay of Monterey was suddenly and severely tossed about by the sea, and the shock was felt on the shore at the same time. At ten o'clock on the 26th December, 1827, a slight shock was felt at San Josef. The shocks are said to come along the coast from the northward, and when they are also felt at Monterey it is some minutes later.

"One was perceived at the Presidio of San Francisco in the month of April, 1827. It continued a short time, but the shaking was so slight that it injured nothing.-C."

Bell, William A. New tracks in North America. London, 1870. $564 \mathrm{pp}$.

Gives history of mining under the Spaniards, mines along the Colorado, etc. pp. 426 et seq.

Berry, George. The gold of California. London, 1849.

Blake, W. P. Notice of remarkable strata containing the remains of Infusoria and Polythalamia in the Tertiary formation of Monterey, California. Philadelphia, 1855. tract.

Observations on the characters and probable geological age of the sandstone formation of San Francisco. Washington, 1855. tract.

Observations on the extent of the gold region of California and Oregon, etc. New Haven, 1855. tract. (In Am. Jour. Sci., Vol. 20, pp. 72-85.)

Remarks upon the geology of California. Washington, 1855. tract.

Sur l'action des anciens glaciers dans la Siérra Nevada de California, et sur l'orgine de la Vallée de Yo-Semite. Paris, 1867. tract. 4to. 
Blake, W. P. Note upon the occurrence of fossil remains of the tapir in California. New Haven, 1868. tract.

- Geological reconnoissance in California. New York, 1858.

The production of precious metals. New York, 1869.

Borthwick, J. D. Three years in California. Edinburgh, 1857. 384 pp. illustrated.

Chapter XIX treats of the northern and southern mines.

Bound Hoye, or the Gold-Hunter's Manual. New York, 1852.

Bouchacourt, C. Notice industrielle sur la Californie. Lyons, 1849 .

Bourne, B. F. Captive in Patagonia. Boston, 1853.

Contains much about California.

Bowre, Aug. J. Hydraulic mining in California. San Francisco, 1878.

- Practical treatise on hydraulic mining in California. New York, 1885. 313 pp. 72 plates and illustrations.

- Same. New York, 1887. 313 pp. maps, plates, and sections.

— Mining débris in California rivers. 80 pp. 5 plates.

Bowman, Aros. Coast surface and scenic geology of California, 1873. 8 plates.

- Report on the properties and domain of the California Water Company, situated on Georgetown Divide; embracing the mining, water, and landed 'resources of the country between the South and Middle Forks of the American River, in El Dorado County, California. San Francisco, 1874. 225 pp. maps, plates, and illustrations.

The report contains a section on vein systems, their origin and relations.

Brooks, J. T. Four months among the gold-finders in Alta California. London, 1849. $207 \mathrm{pp.}$ 
Browne, J. Ross. The Coast Ranges; a chronicle of events in California. A series of articles in Harper's Magazine for 1861-62.

June number, 1861, Vol. XXIII, No. 1, pp. 1-14.

August number, 1861, Vol. XXIII, No. 2, pp. 306-316.

September number, 1861, Vol. XXIII, No. 3, pp. 593-606.

December number, 1861, Vol. XXIV, No. 4, pp. 1-16.

February number, 1862, Vol. XXIV, No. 5, pp. 289-301.

Bryant, Edwin. What I saw in California. Being a journal of a tour by the emigrant route and South Pass of the Rocky Mountains across the continent of North America, the Great Basin, and through California, in the years 1846 and 1847. London, 1849. $412 \mathrm{pp}$.

The appendix gives an account of the discovery of gold mines in California.

Buffum, E. Gould. Six months in the gold diggings, and scenes in Upper and Lower California, from 1847 to 1850. Philadelphia, 1850. $172 \mathrm{pp}$.

Chapter VIII treats of the extent and richness of the California gold fields.

Burnett, Peter H. Recollections and opinions of an old pioneer. New York, 1880. 448 pp.

Chapter VI treats of the gold discovery in California.

Butler, A. W. Resources of Monterey County. San Francisco, 1875.

California Gold Regions, with a full account of the mineral resources, etc. 'New York, 1849. 48 pp.

California; its gold and its inhabitants. London, 1856. 2 vols.

Description of the recently discovered petroleum region in California. New York, 1865. tract.

_- Its past history; its present position; its future prospects, etc., with an appendix containing the official reports made to the Government of the United States. London, 1850. $270 \mathrm{pp}$. 
Califorain, Life in; by an American. New York, $1846.341 \mathrm{pp}$.

On page 90 the author speaks of visiting a spot on the Alisal, near Monterey, from which considerable quantities of silver ore had been obtained. It was the first mine discovered in California, from this author's account.

California as it is. Being a concise description of the State by counties, with memoranda of the progress of each agricultural, horticultural, mining, and other industries up to the year 1887-88, etc. San Francisco, 1888. $257 \mathrm{pp}$. map.

There are five editions of this work. The first one was published by the Daily and Weekly Call in 1882 .

Carpenter, Philip P. Lectures on the shells of the Gulf of California. Washington. $25 \mathrm{pp} .6$ illustrations.

This aticle appeared in the Annual Report of Smithsonian Institution, 1859.

Carsor, J. H. Early recollections of the mines. Stockton, 1852.

Castanares, Manuel. Letters from California addressed to the President of the Republic of Mexico. City of Mexico, 1845.

Manuel Castanares was a Representative in the National Congress, from the Department of California, in 1845. In his first letter, under date of March 2,1844, the author. states that gold placers were discovered in California last year, extending some thirty leagues. In his second letter, under date of September 1, 1844, the writer states : "The mining interest in California is of great importance, and I have the satisfaction of assuring your Excellency that it forms one of the most valuable resources of this Department. Besides the silver mines which are found, there are various other mines which have actually yielded metals; the gold placer especially is worthy of great attention, which extends nearly thirty leagues, was discovered lately, together with mines of mineral coal."

Claudet, F. G. Gold. New Westminster, 1871.

Corgnet, M. Rapport sur les mines de New Almaden. Paris, 1866.

Colton, Walter. The Land of Gold, or three years in California : a diary from 1846 to 1849 . New York, 1860. $456 \mathrm{pp}$.

Chapter XXVII treats of the gold region, its locality, nature, and extent. Chapter XXX treats of the gold-bearing quartz, their locality, richness, and extent. 
Cooper, A. S. The genesis of petroleum and asphalt in California. Scientific American Supplement, September 2, 1893, and December 30, 1893.

Red shales, as connected with the genesis of bitumen in California. The most important asphalt deposits in California are in Tertiary rocks. In Kern County they occur in veins and superficial beds; in Santa Cruz County, bituminous beds are mined; in San Luis Obispo County, in strata and as superficial deposits from springs; in Santa Barbara County, mixed with sand and other substances found in veins and beds, and in sandstone and shale; in Ventura County, in irregular veins and impregnating sandstone.

Cooper, Dr. J. G. Resources of San Luis Obispo County. San Francisco, 1875.

Cony, Thomas G. Gold from California. Lecture, March 25, 1856.

Coulter, Thomas. Notes on Upper California. In Geog. Soc. Journal, Vol. 5, 1835, pp. 59-69.

Cronise, Titus F. The natural wealth of California. San Francisco, $1868.696 \mathrm{pp}$.

Comprising early history; geography, topography, and scenery; climate ; agriculture and commercial products ; geology, zoölogy, and botany; mineralogy, mines, and mining processes; manufactures; steamship lines, railroads, and commerce ; immigration, population, and society; educational institutions and literature; together with a detailed description of each county, its topography, scenery, cities and towns, agricultural advantages, mineral resources, and varied productions.

Chapter VI treats of geology of the State; principally taken from Professor Whitney's reports, Pacific Railroad Reports, and Blake's Geological Reconnaissance in California, etc.

Dana, James D. Manual of Geology, treating of the principles of the science, with special reference to American geological history. 2d edition. New York, 1874. $828 \mathrm{pp}$. (Third edition, New York, 1895.)

This work' contains special articles on California artesian 'wells, p. 654 ; also, notes on the Carboniferous, Cretaccous, Jurassic, Quaternary, sub-Carboniferous, Tertiary, and Triassic formations; with references to geysers, hot springs, human relics, and terraces in California.

Davies, William O. Report of the Pacific Coal Company. New York, $1865.10 \mathrm{pp}$.

Contains report of borings by W. O. Davies; coal fields on the Marsh ranch, in Contra Costa County, with section showing the dip of veins. 
Davison, Simpson. The discovery and geognosy of the gold deposits in Australia, with comparisons and accounts of the gold regions of California, etc. London, 1860. $36 \mathrm{pp}$.

Devoted to personal experience in the gold mines of California.

Delaxo, A. Life on the plains and among the diggings. Being scenes and adventures of an overland journey to California, with particular incidents of the route, etc. Auburn and Buffalo, 1854. $384 \mathrm{pp}$.

Chapter XXVII treats of the resources of California, mineral wealth, etc.

Delessert, B. Les mines d'or de la Californie. 17 pp. tract. (Rev. d. Deux Mondes, Vol. 5, 1849, p. 468.)

Delmar, Alexander. A history of the precious metals. London, 1880.

Denis, Ferd. Les Californiens. Paris, 1849. pamphlet. $45 \mathrm{pp}$.

This is an historical account of the settlement of California.

Dunbar, E. E. Romance of the age, or discovery of gold in California. New York, 1867. 134 pp.

The author gives ąn account of the discovery of gold in California, with a brief history of previous accounts of gold mentioned by writers before 1848 .

Elmore, M. G. Esmeralda mining map. New map of the Esmeralda mining district to December, 1862. San Francisco, 1862.

These mines are south of Washoe, on the eastern slope of the Sierra Nevada, and partly in California.

Evans, Albert S. A la California. Sketches of life in the Gold State. San Francisco, 1873.

The author gives passing references to mining, with illustrations.

Farnhan, T. J. Life and adventures and travels in California. New York, 1852. 514 pp.

- Same. New York, 1857. 468 pp. illustrated.

Fedix, - Les côtes des Pacifique. Paris, 1846. 258 pp. maps. 
Ferry, Hypolite. Description de la nouvelle Californie, geographique, politique, et morale. Paris, $1850.386 \mathrm{pp}$.

Chapter III treats of the climate and mountain chains.

Chapter IV treats of the auriferous regions of California.

Feuchiwanger, Dr. Louis. Valuable mining tables for ascertaining the weight of a cubic foot of any ore, metal., etc. (In California Farmer, Vol. 29, No. 14, April 9, 1868. Also published as broadside.)

Fortune, H. W. Report of the property of Trinidad Copper Mining Company, Lower California: San Francisco, 1879. $11 \mathrm{pp}$. sections.

Foster, G. G. The gold regions of California. Being a succinct description of the geography, history, topography, and general features of California: including a carefully prepared account of the gold regions of that fortunate country, prepared from official documents and other authentic sources. New York, 1848. $80 \mathrm{pp}$. and map.

Frignet, Ernest. La Californie Histoire-organisation, politique et administrative, Législation, Description, Physique et Géologique, Agriculture, Industrie, Commerce. Paris, 1866. $471 \mathrm{pp}$.

Livre 3, Chap. I, treats of the geology.

Frémont and Eyory. Notes of travel in California, comprising the prominent geographical, agricultural, geological, and mineralogical features of the country; also the route to San Diego, in California, including parts of the Arkansas, Del Norte, and Gila Rivers. Dublin, 1849. $311 \mathrm{pp}$.

Frost, John. History of the State of California. Auburn, 1850. $508 \mathrm{pp}$.

Chapter XIII treats of the mineralogical and other characteristics of gold, etc.

GEology of California, the supply of silver and gold. tract. 19 pp. (N. Amer. Rev., Vol. 75, 1852, p. 277.)

Gilpix, Williny. The central gold region; the grain, pastoral, and gold regions of North America, with some new views of its physical geography; and observations on the Pacific Railroad. Philadelphia, 1860. 194 pp. maps. 
GoLD mines and mining in California. A new gold era dawning on the State; progress and improvements made in the business; perfected methods; progress and machinery; vast extent of auriferous territory; rich and varied character of deposit; a country abounding with elements of success; grand field for the profitable investment of the world's surplus capital. San Francisco, 1885.

Under the general heading of Hydraulic Mining, pp. 63-82, the author gives a few geological notes on the Pliocene rivers. On p. 333 , a short account of the auriferous deposits peculiar to California. The Gold Bluffs and beaches is given, with a description of those of Humboldt County.

Goodyear, W. A. The coal mines of the western coast of the United States. San Francisco, 1877. 153 pp.

The part relating to California was republished, with additional notes and corrections, in the Seventh Annual Report of the State Mineralogist.

Gregory, J. G. Guide to California and the Isthmus of Panama. New York, 1850.

Hanks, Henry G. Address of the President of the California State Geological Society. Daily Alta, January 8, 1877.

_ Geological Society. Celebration of the first anniversary of the organization. Daily Alta, December 6, 1877.

These two papers were issued in pamphlet. They contain a list of private owners of mineral collections; also, notes on diatomaceous earth of the Pacific Coast.

Catalogue of the minerals, ores, rocks, and fossils of the Pacific Coast exhibition at the Paris Exposition of 1878. pp. i-xxiv and 1-99.

Coal and iron interest of the Pacific Coast. San Francisco, 1888. tract.

- Notes on mica. San Francisco, 1882. tract.

- The deep placers of California. In Mining and Scientific Press, 1890.

Magnesia and its base and compounds, with particular reference to magnesite. San Francisco, 1895. 27 pp. 
Hart, Albert. Mining statutes of the United States, California, and Nevada. San Francisco, 1877. 183 pp.

Hastings, L. W. A new description of Oregon and California, containing complete descriptions of those countries, together with the Oregon treaty and correspondence, and a vast amount of information relating to the soil, climate, productions, rivers and lakes, and the various routes over the Rocky Mountains; also an account, by Col. R. B. Mason, of the gold region, and a new route to California. Cincinnati, 1849. $168 \mathrm{pp}$.

Helper, H. R. Land of gold: reality vs. fiction. Baltimore, 1855. $300 \mathrm{pp}$.

Hittell, John S. The resources of California, comprising agriculture, mining, geography, climate, commerce, etc., and the past and future development of the State. 5th edition, with an appendix on Oregon, Nevada, and Washington Territory. San Francisco, 1869. 504 pp.

The first edition of this work was published in 1862. Chapter III treats of geology. There is also a chapter on mining.

Edition published in San Francisco, 1863, 1 vol., large 12mo, contains $461 \mathrm{pp}$; ; another edition in 1866, 1 vol., large $12 \mathrm{mo}$.

Holland, Charles. Mines and mining. In the Coast Review, 1873, p. 73.

Huse, Charles E. Sketch of the history and resources of Santa Barbara city and county. Santa Barbara, 1876.

Hutchings, J. M. Scenes of wonder and curiosity in California. 1860. 236 pp. 92 illustrations.

- Another edition. London, 1865. 267 pp. 100 illustrations.

Another edition, to which is added a tourist guide to the Yosemite Valley. New York, 1876. 292 pp. 100 illustrations.

Huntley, Sir Henry. California; its gold and its inhabitants. London, 1856.2 vols. 
JACKson, —. Map of the mining districts of California. 1851. Colored map, $18 \times 22$ inches.

The appendix to this map contains 16 pages.

JACkson, C. T. The oil interest of southern coast of California. San Francisco Bulletin, July, 1865.

Johnson, T. T. Oregon and California, or sights in the gold region and scenes by the way. New York, 1849. 290 pp. (Also published New York, 1850. 324 pp.)

Chapters XXVII and XXVIII treat of the gold regions, volcanic formations of California, etc.

The first edition was published in 1849. A second edition was published in April, 1850, with the addition of eight new chapters, viz., Chapters VI, XXV, XXVI, XXVII, XXVIII, XXIX, XXXI. There were no illustrations in the first edition.

Kelly, William. Excursion to California over the prairie, Rocky Mountains, and Great Sierra Nevada, with a stroll through the diggings and ranches of that country. London, 1851. Vol. 1, 342 pp.; Vol. 2, 334 pp.

King, Clarence. Mountaineering in the Sierra Nevada. Boston, 1872. $292 \mathrm{pp}$.

Kivg, T. Butler. Report on the metallic and mineral wealth of California. Appendix to Taylor's El Dorado. New York, 1850.

Kneeland, S. Wonders of the Yosemite Valley and of California. 97 pp. 2 maps. 10 photos.

Kustel, Guido. Concentration and chlorination of gold-bearing sulphurets, etc. San Francisco, 1868. 259 pp.

Roasting of gold and silver ores. New edition. San Francisco, 1880. 156 pp.

Nevada and California processes of gold and silver extraction.

Laur, P. De la production des Metaux precieux en Californie. Paris, 1862. 132 pp.

- Du gisement et de l'exploitation de l'or en Californie. In Ann. des Mines, Vol. 6, ser. 3, pp. 347-435. 
LAUR, P. Terrains aurifères de la Californie. 20 pp. In Rev. d. Deux Mondes, Vol. 5, 1863, p. 453.

Le Conte, Joseph. Elements of geology; a text-book for college and general readers. 2d edition. New York, 1878. $588 \mathrm{pp}$.

This work is of special interest to the student of California geology, containing many references to the geology of the State. We note an article on auriferous veins, given on p. 237; also, Quaternary period on the western side of the continent, p. 526 .

Levasseur, R. La question d'or, les mines de Californie et d'Australie, les anciennes mines d'or et d'argent. Paris, 1858.

Levy, Daniel. Les Français en Californie. San Francisco, 1884. $366 \mathrm{pp}$.

The second part of this book treats rather extensively of the placer mines, where they were located, how worked, etc. pp. 80 et seq.

Lock, Alfred G. Gold; its occurrence and extraction, etc. London, 1882. $1229 \mathrm{pp}$.

The description of the California gold fields is given on pp. 129-154.

Macfarlane, Janes. The coal regions of America; their topography, geology, and development; with a colored geological map of Pennsylvania, a railroad map of all the coal regions, and numerous other maps and illustrations. Third edition, with a supplement for the year 1875. New York, 1877. 697 pp., with maps, etc.

Chapter XXX treats of the Pacific Coast region. A description of the Mount Diablo coal field is given on pp. 563-567, with analyses of the coal.

Marcou, Jules. American geological classification and nomenclature. Cambridge, $1888.75 \mathrm{pp}$.

The author remarks on p.44: "In California, the Cretaceous is limited to the northwest corner of the State, and occupies a small area west of Mount Shasta. The Geological Survey of California, directed by Mr. J. D. Whitney, has called Cretaceous all the Eocene of Fort Tejon and Chico Creek."

Geology of North America; with two reports on the prairies of Arkansas and Texas, the Rocky Mountains of New Mexico, and the Sierra Nevada of California, originally 
made for the United States Government. Zurich, 1858. 144 pp. 7 plates and 2 geological maps.

This work contains :

Chapter I. Résumé of a geological reconnoissance extending from Napoleon, at the junction of the Arkansas with the Mississippi, to the Pueblo de los Angeles, in California. The following Californian fossils are described: Fossils of the Tertiary rocks-Ostria Virginica, var. Californica, Colorado Desert; Spirifer striatus, Mart., Shasta County, California.

Chapter V. On the geology of the United States and British Provinces of North America. Geological map of North America. (Extract from Dr. Petermann's Geographischen Mittheilungen, Heft. 6, in 4to. Gotha, 1855.) Contains a notice of the California Desert, or Great Basin, the Cascade Range, the Coast Range.

Chapter VI. Sketch of a geological classification of the mountains of a part of North America. (Extract from Annales des Mines, 5 ser., tome vii, p. 329. Paris, 1855.) Contains description of Coast Range and Sierra Nevada system.

Chapter VII. On the gold of California. (Extract from Bibliothéque Universelle de Genève. Février, 1855.)

Mariposa Gold Company Reports, by Garnet and Wakeley. 1863. $81 \mathrm{pp}$. col. map.

Mariposa Estate. London, 1861. 63 pp. map.

Mariposa Estate (The), its past, present, and future. Comprising the official report of J. Ross Browne upon its mineral resources. Transmitted to Congress, March 5, 1868. New York, 1868. $62 \mathrm{pp}$.

Marryat, Frank. Mountains and mole hills. New York, 1855. $393 \mathrm{pp}$.

This is an account of three years in California. Refers to the gold diggings on American River and other places, on p. 210 et seq.

Maxly, W. L. Death Valley in 1847. San José, 1894. 498 pp.

Manson, Marsdex. Geological and solar climates: their causes and variations. A thesis, University of California, May, 1893. San Francisco, 1894. 49 pp.

McGarrahan, Willian. The quicksilver mines of Panoche Grande. Washington, 1860.

Memorial of the New Idria Mining Company, in the matter of the Panoche Grande Rancho. 1867. 16 pp. 
Mines And Minisg in El Dorado County. The mineral belt, its slates and ores; deep mining, principal mines, etc. San Francisco, 1882. 14 pp.

Mofras, Dufiot De. Exploration des Territoire de l'Orégon, des Californies et de la Mer Vermeillo, exécutée pendant les années 1840,1841 , et 1842 . 2 vol. $8^{\circ}$, avec un Atlas in folio. Paris, 1844. Published by order of the King, under the auspices of the President of the Council and Minister of Foreign Affairs. Vol. I, 521 pp., 4 plates; Vol. II, 387 pp., 4 plates. Atlas of 26 sheets, maps, and plans.

This author states (Vol. 1, p. 489) that a vein of gold-bearing quartz was worked near the Mission of San Fernando by M. Baric in 1843.

According to De Mofras, the gold of the San Francisquito Rancho was first explored by M. Charles Baric. He gives its distance in the mountains as six leagues to the northward of the Mission of San Fernando, and fifteen leagues from Los Angeles. He further states: "This vein has an extent of six leagues, following the direction of the ravine where it is situated. The gold is found near the surface of the soil, and some pieces weighed two or three drachms." This description would lead one to the opinion that the deposit was a placer one and not a vein, although he uses the word filon.

According to De Mofras, silver ores occur about two leagues northwest of Cahuenga Rancho, and were not worked for want of mercury. He further observes that the Indians often bring in from the mountains, grains of copper, fragments of opal, and pieces of galena. Mines of gold and silver are also said to have been found about fourteen leagues from San Diego. They were once worked by a man from Guanajuata.

There is a notice of the bitumen near Los Angeles on p. 337, vol. 2. The author states: "Two leagues to the southeast of Los Angeles there are four great sources of asphaltum, situated on a level with the earth in a vast prairie. These springs open in the middle of little pools of cold water, while the bitumen possesses a higher temperature. This water has a mineral taste, which, however, does not prevent animals from drinking it. At sunrise the orifices of these springs are covered by enormous bubbles of asphaltum, often being more than a yard high, and looking like soap bubbles."

Molitọ, A. P. Essay on California gold. San Francisco, 1860.

This work is said to be a very valuable essay on this subject.

Mowry, Sylyester. The mines of the West. New York, 1864.

Murr, J. Living glaciers of California. In Harper's Mag., Vol. 51,1875, pp. 769-777. 
Murchison, Sir R. Siluria: A history of the oldest rocks in the British Isles and other countries; with sketches of the origin and distribution of native gold, the general succession of geological formations, and changes of the earth's surface. 1st edition, London, 1854 ; geological map and 37 plates of fossils. $2 d$ edition, London, - . $3 \mathrm{~d}$ edition, London, 1859 ; geological map and 41 plates of fossils. 4th edition, London, 1867 ; geological map and 42 plates. 5 th edition, London, 1872 ; with geological map and atlas of 42 plates.

The author notes the California gold field on p.470. He remarks in conclusion: "1. That, looking to the world at large, the auriferous veinstones in the lower Silurian rocks contain the greatest quantity of gold ; 2. That where certain igneous eruptions penetrated the Secondary deposits, the latter have been rendered auriferous for a limited distance only beyond the junction of the two rocks; 3 . That the general axiom before insisted upon remains: that all Secondary and Tertiary deposits (except the auriferous detritus in the latter) not so specially affected never contain gold."

Nordhoff, Charles. California for health, pleasure, and residence: a book for travelers and settlers. New York, 1873. $255 \mathrm{pp}$.

Contains notice of gold mining, with a few geological notes.

Old River-Bed Gold Mining Company. Report, 1879. New York. $18 \mathrm{pp}$.

The mines of this company are situated in Butte County, on the west branch of the Feather River. The report contains reports and sections, by J. H. L. Tuck and R. H. Stretch, on the old Pliocene river-beds of California, with sections of the west branch of Feather River, Butte County, California.

Oregon and California : Account of gold regions, methods of testing gold, etc. $1849.76 \mathrm{pp}$. col. map.

Pacific Coast Petroleum Company lands in San Luis Obispo County. 1865. $15 \mathrm{pp}$.

Palmer, Gen. Wy. J. Report of surveys across the continent in 1867-68, on the 35th and 32d parallels, for a route extending the Kansas Pacific Railway to the Pacific Ocean at San Francisco and San Diego. Philadelphia, 1869. 250 p. maps.

Contains a report by Dr. C. C. Parry, geologist and naturalist to the Survey, on the mineral districts of Central and Western Arizona and Southern California. 
Pfeiffer, E. J. Sketch-map of the Forest Home and Willow Springs Copper Mining District, Amador County. San Francisco, 1864.

Phillips, John Arthur. Notes on the chemical geology of the gold fields of California. London, 1868. tract.

- Gold mining and gold discoveries made since 1851. London, 1862. tract.

- The mining and metallurgy of gold and silver. London, 1867. tract.

Phillips, John S. Explorers and assayers' companion; rocks, veins, testing, and assaying. 2 vols. San Francisco, 1879 .

Player-Frowd, J. G. Six months in California. London, 1872. $164 \mathrm{pp}$.

A sketch of the general geological features of California is given on pp. 48-57; of mines and mining, on pp. 85-108.

Quicksilver: Facts concerning mines in Santa Clara County, California. New York, 1859.

Rayos, J. M. Informe relativo à los Trabajos ejecutados por la comision exploradora de la Baja California. Mexico, 1886. $222 \mathrm{pp}$. maps and geological sections.

Raven, RaLph. Golden dreams and leaden realities; with introduction by F. Fogie. New York, 1853. 344 pp.

RÉmond, A. Report of an exploration and survey of the coal mines of Monte Diablo district. San Francisco, 1861.

Contains small sketch-map in black, showing Tertiary hills.

Revere, J. W. (Lieut. U. S. Navy). A tour in California, including a description of the gold region and an account of the voyage around Cape Horn, etc. New York, 1849. $305 \mathrm{pp}$. maps and illustrations.

Chapter XIX treats of the gold regions. It also contains the official report of Colonel Mason, etc.

Rouinson, Fayetr. California and the gold regions, with a geographical and topographical view of the country, its 
mineral and agricultural resources, prepared from official and other authentic documents; with a map of the United States and California, showing the routes of the U.S. mail packets to California; also the various overland routes. New York, 1849. 137 pp.

Chapters I and II contain reports of the gold mines, with early accounts of the existence of gold in California.

This book also contains a synopsis of Mr. Larkin's and Colonel Mason's reports.

Ruxton, C. F. Life in the far West. New York, 1859. 235 pp.

Silversmith, J. Metallic and agricultural wealth of the Pacific States. $1863.150 \mathrm{pp}$. illustrated.

Seyd, Ernest. California and its resources. London, 1858. 168 pp. maps.

Contains a chapter on gold mining, and references to other minerals; etc.

SEymour, E. S. Emigrants' guide to the gold mines. Chicago, 1849.

Shaler, N. S. California earthquakes. In Atlantic Monthly, Vol. 25, 1870, p. 351.

Shaw, William. Golden dreams and waking realities. Being the adventures of a goldseeker in California and the Pacific Islands. London, 1851. $316 \mathrm{pp.}$

Shins, Charles H. Mining camps: a study on American frontier government. New York, 1885. $316 \mathrm{pp}$.

Silliman, B. Petroleum region in California. 1864. 21 pp., with one plate.

Report upon the oil property of the Philadelphia and California Petroleum Company. Philadelphia, 1865. $36 \mathrm{pp}$.

- On petroleum in California. National Intelligence, February $7,1866$.

Simonin, Lours. La vie Souterraine, ou les mines et les mineurs. Paris, 1867.

Contains Cartes des gîtes miniers des États de la Californie et Nevada. 
Simpsor, Henry J. The emigrant's guide to the gold mines. New York, 1848.

Solignac, Armond de. Les Mines de la California. Limoges, 1852. $98 \mathrm{pp}$.

This book is a narrative of the author's trip to California. There is very little about the mines, except on page 53 , where he gives a short description of the placers on the American River.

Stetefeldt, C. A. The lixiviation of silver ores with hyposulphite solutions, with special reference to the Runell process. New York, 1888. $223 \mathrm{pp}$.

Stewart, W. M. Lecture on the mineral resources of the Pacific States. New York, 1865.

Stillman, J. D. B. Seeking the Golden Fleece. San Francisco, 1877. $352 \mathrm{pp}$. illustrated.

This work is in the shape of a journal. On page 157 the author gives an account of mines, etc.

Stone, R. C. Gold and silver mines of America. New York.

TAYlor, BAyard. El Dorado: Adventures in the path of empire. New York, 1850.

In the appendix there is a report of Hon. T. Butler King, on the metallic and mineral wealth of the State. pp. 201-247.

TAYLoR, R. C. Statistics of coal. The geographical and geological distribution of mineral combustibles or fossil fuel; including, also, notices and localities of the various mineral bituminous substances employed in arts and manufactures. Illustrated by maps and diagrams,.etc. Philadelphia, 1848.

Under the heading of Upper California, the author states: "In the spring of 1847 , a new coal mine was discovered near San Luis Obispo, N. Lat. $35^{\circ}$. There are now three mines within three hundred miles of Monterey. Asphaltum and petroleum occur abundantly in Western California."

Same. Second edition, revised and brought down to 1854, by S. S. Haldeman. Philadelphia, 1855.

Notes a report of Dr. Le Conte on the, discovery of coal, 12 miles north of San Diego, in 1851. 
Tegoborski, M. L. DE. Essai sur les conséquences éventuelle de la déconverte des gites aurifères en Californie et en Australie. Paris, 1853. $199 \mathrm{pp}$.

The Piute Company of California and Nevada; organized April 13, 1869, incorporated June 30, 1870. San Francisco, 1870. 23 pp. 21 plates, and map.

This report contains excellent maps of the mining region, in San Bernardino County, California, and the adjoining Yellow Pine District, in Nevada. A few geological notes are given in the descriptions of the different mines.

The New Almaden Mines. Letters from the San Francisco "Daily Herald," as published on the mornings of the 15th, 17th, and 18th of December, 1858. San Francisco, 1858. pamphlet.

Thorstox, J. Quins. Oregon and California in 1848, with an appendix including recent and authentic information on the subject of the gold mines of California and other valuable matter of interest to the emigrant, etc. New York, 1849. 2 vols.

The appendix to Vol. 2, pp. 267-379, contains an account of the gold region of California, which is principally a copy of the official reports made in 1848.

Trask, Dr. John B. Earthquakes in California from 1800 to 1863. San Francisco, 1864. 26 pp.

Dr. Trask also published several articles on the same subject in the Proceedings of the California Academy of Sciences.

- Topographical map of the mineral districts of California, being the first map ever published from actual survey. San Francisco, 1853.

Trény. La Californie dévoilée du vérités irrécusable appuyées sur le nombreux témoignages sur cette partie du globe. Paris, 1850. $60 \mathrm{pp}$.

This pamphlet was issued in three editions.

Tripp, D. K. Report of the examination and survey of the Sonoma Pacific coal mines. Report 1888. San Francisco, 1888.

These mines are located about two and one half miles from Santa Rosa. The report gives several analyses of the coal, by D. K. Tripp. 
Turrill, Charles B. First volume-California Notes. San Francisco, 1876. $232 \mathrm{pp}$.

This book contains a chapter on the topography of California, with notes on the gold mines and geology of gold section.

Tysos, J. L. Diary in California. Baltimore (?), 1850. 92 pp.

Upham, Samuer G. Notes of a voyage to California via Cape Horn; also, scenes in El Dorado, 1849 and 1850. Philadelphia, 1878. 594 pp.

Veatch, John A. Letter from Dr. John A. Veatch to the Borax Company of California, June 28, 1857. San Francisco, 1857. $16 \mathrm{pp}$.

Dr. Veatch discovered borax at Borax Lake, Lake County, in 1856.

Walton, Daniel. Facts from the gold region. Boston, 1849.

WAsson, Jos. Bodie and Esmeralda. Being an account of the revival of affairs in two singularly interesting and important mining districts, including something of their past history, and the gist of the reports of Profs. Benj. Silliman and W. P. Blake, the late J. Ross Browne, R. H. Stretch, State Mineralogist, and H. R. Whitehill; also, detailed descriptions of mines most developed, tunnels, mills, etc. San Francisco, 1878. 60 pp.

Wells, W. V. How we get gold in California. In Harper's Mag., Vol. 20, 1860, p. 598. 19 pp.

Werti, Johr J. A dissertation on the resources and policy of California: minerals, agriculture, and commerce, including a plan for the disposal of the mineral lands. Benicia, 1851. $87 \mathrm{pp}$.

Weston, S. Four months in the mines of California. Providence, 1854.

Whitney, J. D. The metallic wealth of the United States described and compared with that of other countries. Philadelphia, 1854. $510 \mathrm{pp}$.

An account of the gold, with the geology of this region, in California, is given on pp. 134-149. 
Wintmey, J. D. Letter of Professor Whitney, State Geologist of California. In the Mariposa Estate, London, 1861, pp. 5-7.

Woods, Daniel B. Sixteen months at the gold diggings. New York, 1851. $199 \mathrm{pp}$.

The appendix contains a letter from Prof. Edward Hitchcock on the gold mines of California.

Wright, G. F. The Ice Age in North America, and its bearings upon the antiquity of man, by G. Frederick Wright; with an appendix on the probable cause of glaciation, by Warren Upham. New York, 1889. 622 pp. maps and many illustrations.

The author notices the existing glaciers of California, ancient glaciers, the terminal moraines of California, the pre-historic man in California, ancient river-beds, etc.

WYLD, J. Guide to California. London, 1849.

Notes on the distribution of gold throughout the world, including Australia, California, and Russia. London, $2 \mathrm{~d}$ edition, 1851; $3 \mathrm{~d}$ edition, 1853.

- Geographical and mineralogical notes to accompany Wyld's map of the gold regions. London, 1849.

YALE, Gregory. Legal titles to mining claims and water rights in California. San Francisco, 1867. $452 \mathrm{pp}$.

This report gives the history of early mining legislation in the United States, and especially that of California. 



\section{INDEX.}

Aaron, Leaching gold and silver ores Page.

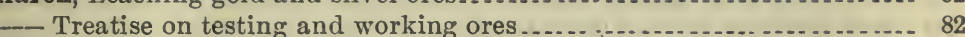

- Assaying; in three parts ............................................. 82

Adams, Catalogue of Panama shells .................................. 58

Agassiz, Notice of fossil fish ......................................... 30

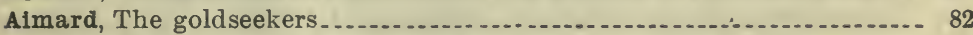

Allen and Avery, California gold book ................................ 82

Allsop, California and its gold mines.... ............................... 82

Anderson, A. D., The silver and gold of the Southwest.................... 82

Anderson, C. L., The natural history of Santa Cruz County .............. 82

Anderson, w., Desiccated human remains in California................... 15

Anonymous, Gold in California ......................................18, 88, 92

- Platinum and diamonds in California............................. 51

- Gold, its discovery and progressive development in the United Stätes. 57

- The Mariposa estate ................................................ 97

- A mammoth tusk .................................................. 63

— Cinnabar at'Point Reyes ........................................... 71

- Geology of American Valley ....................................... 26

— Bound home, or gold-hunters' manual .................. ........... 87

Ansted, The goldseeker's manual ..................................... 83

Antisell, Geology of Captain Parke's exploration ........................ 32

— Fossils from San Luis Obispo County ............................. 61

Ashburner, Geological formation of Pacific Slope....................... 33

- Report of California Water Company ................................ 83

Report of the Sulphur Bank Quicksilver Mining Company ........... 83

— Report on gold quartz mine ....................................... 83

Ashley, An illustration of the flexure of rocks ......................... 66

Studies in the Miocene of California ................................ 70

- Neocene stratigraphy of the Santa Cruz Mountains ................. 66

Attwood, Milling of gold quartz ....................................... 36,83

- Papers on microscopical examination of rocks...................... 83

Aubrey, Notes on routes from Tejon Pass to Santa Fé ... . ............... 28

Bache, Notice of earthquake waves, 1862 ............................. 37

Bailey, Fossil plants from Posumcula River ............................. 31

_ Fossil diatomacex in California .................................... 51

Baird, Ornithology of California .................................... 11

— The water-birds of North America ................................. 12

Barry, Report on proposed Eocene tunnel at Big Bend of Feather River.- 83

Becker, Report on uplift of the Coast Range ............................ 40

— Report on California division of geology ... ......................... 40

Notes on the stratigraphy of California ............... . ............. 42

Geology of the quicksilver deposits of the Pacific Coast .............. 44

Summary of the quicksilver deposits of the Pacific Coast .......... 40

- Relations of mineral belt of Pacific Slope to the great upheavals.... 55 
Becker, Texture of mineral rocks . .

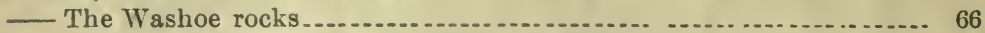

Sketch of geological development of Pacific Coast.....

Geometrical form of volcanic cones . ....... _.....

- Cretaceous metamorphic rocks of California $\ldots \ldots \ldots \ldots$

- Structure of a portion of the Sierra Nevada_........ . . . . . . . . . 58, 83

- Antiquities from under Tuolumne Table Mountain ................. 58

Notes on early Cretaceous of California _.....

Beechey, Narrative of a voyage to the Pacific and Behring Strait........ 83

Behr, Mine drainage, pumps, etc........ ...

Bell, New tracks in North America . . . . . . . . .

Berry, The gold of California . . .

Blake, Rare minerals of California ..................................... 13

- Contributions to the geology and mineralogy of California .......... 14

- Annotated catalogue of California minerals _.

-_ Geographical distribution and geology of precious metals and minerals of Pacific Coast............ .

Geological report of routes in California in 1856 . . . .

Physical geography and geology of coast of California from Bodega

Bay to San Diego . . .

- Geological age of the sandstone formation of San Francisco........45, 86

Grooving and polishing of hard rocks and minerals by dry sand .... 45

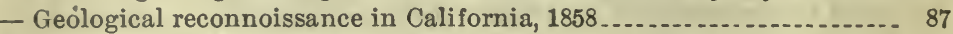

The production of precious metals . _ _ .

Forms in which gold occurs in nature .....

Miscellaneous notices of . . . . .

Sur l'action des anciens glaciers dans la Sierra Nevada .............67, 86

- Observation on the extent of the gold region of California ..........71,86

- Notice of strata containing infusoria, etc., at Monterey . . . . . . . . . . 86

- Remarks on geology of California, 1855 . _ _ _ _ _

Quaternary deposits in California . .

_ Quicksilver mines of Almaden, California _... . . . . . . . . . . . . . . 51

Recent earthquake shocks in California .

- Extent of gold regions of California and Oregon . . . . . . . _ . . . . 52

- On fossil tapir of California _...

_ New mineral oil region in Tulare Valley . . .

Blake, James, Glacial action at Johnson's Pass . ... . . . . . . . . . . . . . . 65

Blankinship, Notes on the geology of the Farallones .................. 80

Borthwick, Three years in California _...

Bouchacourt, Notice industrielle sur la Californie . . . . . . . . . . . . . ... 87

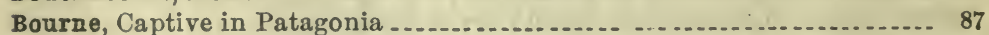

Bowers, Report on Ventura County ..............

Geology of San Nicolas Island . . . . .

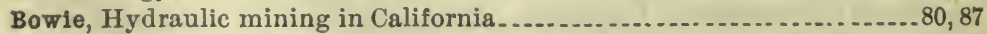

__ Practical treatise on hydraulic mining in California ............... 87

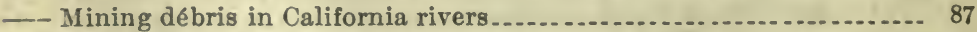

Bowman, Coast surface and scenic geology ............................. 64,87

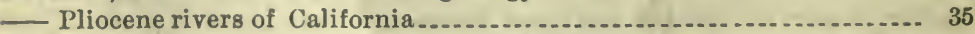

_. Mining development of the northwest Pacific Coast . . . . . . . . . .... 80

_ Geology of the Sierra Nevada in its relation to vein mining ......... 35

- Report on California Water Company ...

Brewer, Reports on botany ............

Brooks, Four months among the gold fields..................... ....... 87 
Brown, C. Page.

, C. J., Extinct rivers of the auriferous belt of California ........... 35

Brown; Robert, On coal fields of north Pacific Coast..................... 68

— Supposed absence of northern drift from Pacific Coast............... 53

Browne, J. Ross, Historical sketch of gold and silver mining on the Pacific Coast

Condition of gold and silver mining on Pacific Coast ........ 33

Copper resources of Pacific Coast .................................... 33

General condition of mining interest in 1868........................ 34

The Coast Range, a chronicle of events in California................. 88

Bryant, What I saw in California .......................................... 88

Buffum, Six months in the gold diggings .............................. 88

Burchard, Reports to United States Mint............................... 36

Burnett, Recollections of an old pioneer............................... 88

Butler, Resources of Monterey County .................................. 88

California, Its gold and its inhabitants ............................... 88

Description of petroleum regions ................................. 88

Its past history and present position ................................ 88

Life in, by an American .......................................... 89

As it is ....... . .

Call, Quaternary and recent mollusca of the Great Basin... ............. 41

Carpenter, Mollusca of the west coast of North America.................68, 89

Supplement to mollusca of west coast of North America ............. 68

- Lectures on shells of the Gulf of California.......................... 89

Carr, On mountain sculpture in the Sierra Nevada, and method of glacial erosion ............................................................ 54

Mountain sculpture in the Sierra Nevada ......... ............... 72

Carson, Early recollections of the mines............................... 89

Castanares, Letters from California _................................... 89

Census, Tenth and Eleventh Census Reports ......................... 37, 38

Chapman, Pliocene Ostracoda........................................ 24

Chase, Klamath River mines .......................

— On auriferous gravel deposits of Gold Bluff ...................... 64

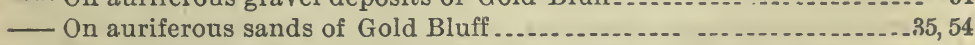

Artesian wells of Los Angeles . .................................... 64

Christy, Report on Mount Diablo coals ................................ 19

The genesis of cinnabar ..........

Clark, Correlation papers, Eocene .................................. 43

Clarke, Petroleum in California ......................................... 35

Clayton, Earthquakes on Kern River................................... 63

The glacial period; its origin and development................... 65

Coignes, Rapport sur les mines de New Almaden.................... 89

Colton, The land of gold .............................................. 89

Conkling, Geology of mountain ranges from La Veta Pass to headwaters of Pecos............................................................. 38

- Geological report of western Nevada and eastern California, between

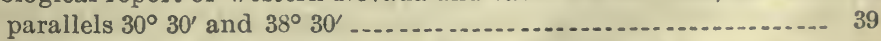

Conrad, Marine shells from Upper California ............................. 73

\begin{tabular}{lll} 
- Notes on Miocene and Post Pliocene deposits of California .......... & 73 \\
\hline Description of fossils from California and one from Texas .......... & 73
\end{tabular}

Description of Cretaceous and Tertiary fossils, Mexican Boundary Survey ..................................................... 28

Description of fossil shells; P. R. Report, Vol. V .................. 30

— Description of Tertiary fossils ; P. R. Report, Vol. VI ............... 31 
Conrad, Palæontology of Captain Parke's'Report; Observation on certain Eocene fossils, described as Cretaceous by W. M. Gabb Observations on Jr. Gabb's palmontology o Califoria California, elevation of, during the Tertiary epoch ................... Fossils from Tertiary deposits on Columbia River .

Reply to Mr. Gabb, on Cretaceous rocks of California.

Cooke, March from Santa Fé to San Diego, 1848

- Journal of march of Mormon battalion from Santa Fé to San Diego, 1849

Cooper, A. S., The genesis of petroleum

Cooper, J. G., Catalogue of mollusca from west of the Rocky Mountains.. On some Pliocene fresh-water fossils of California ...... . . . . . . . . . .

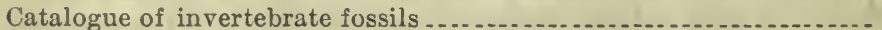
On fossil and sub-fossil land-shells of the United States .............. Catalogue of fossils, 1888 The value of fossils as indications of important mineral productions.. Catalogue of California fossils; parts 2-5 ............................ Catalogue of Vest North American shells .............................. On the discovery of lignites in Amador County .................... Age of the Tejon group Remarks on California coal

California during Pliocene epoch

California during Miocene epoch

The Eocene epoch in California

Notes on Tertiary formation of California

West Coast pulmonata, fossil and living .............................

Resources of San Luis Obispo County ................................

Cope, Mesozoic and Cenozoic realms in North America...................

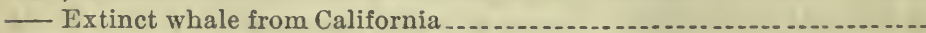

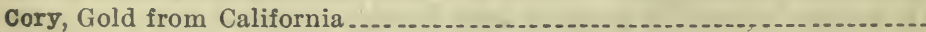

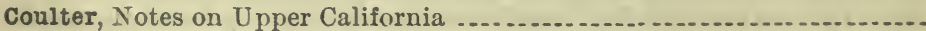

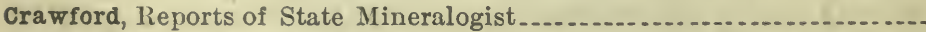

Cronise, Natural wealth of California....................................

Crosby, Origin of continents ..........

Crossman, Report on San Bernardino County .............................

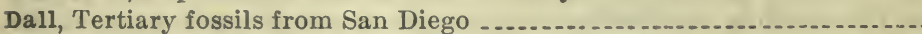

- Post Pliocene fossils of Coast Range of California...................

Distribution of California Tertiary fossils

Dana, Geology, United States Exploring Expedition .....................

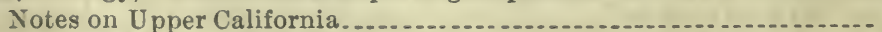
Manual of geology ....................................................

Davies, Report of Pacific Coal Company ..................................

Davis, Remarks on certain geological specimens ...........................

Davison, H., Remarks on surface geology, as affected by upheavals........

- Remarks on the first discovery of glaciers ......... . ................

— Remarks on recent earthquake wave ............................... Abrasions of the continental shores of northwest A merica ......... 64

Davison, simpson, The discovery and geognosy of the gold deposits in Australia, etc. ... .............................................. 91

Day, Reports on mineral resources of United States ................. .40,41 Deetken, Treatment of gold ores...... ................................ 35 
Page,

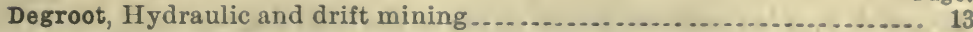

Delano, Life on the plains and among the diggings .................... 91

Delessert, Les mines d'or de la Californie ....... . . . . . . . . . . . . . . . . . ... 91

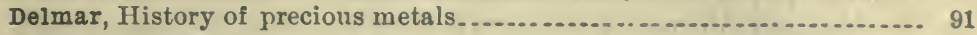

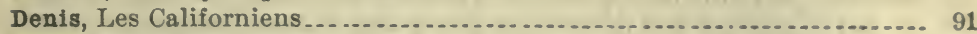

Derby, Topographical memoir, with map of the Sacramento Valley ...... 27

Diller, Coal in the Chico group of California ........................ 77

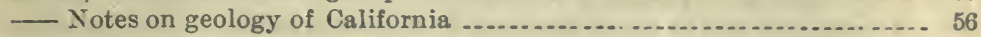

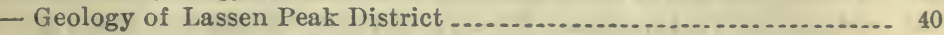

— Volcanic eruption in Northern California . . $\ldots \ldots \ldots \ldots \ldots \ldots \ldots \ldots \ldots \ldots \ldots . . .56$

- Tertiary revolution in the topography of Pacific Coast............... 41

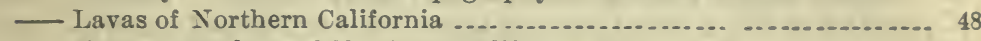

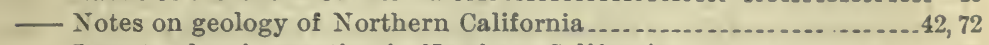

L Latest volcanic eruption in Northern California......... . . . . . . . . .. 43

— Notes on Cretaceous rocks in Northern California ................... 57

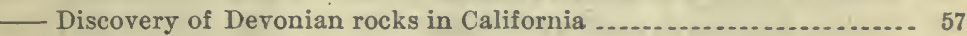

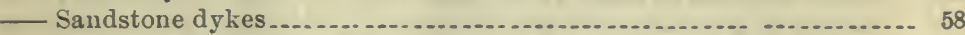

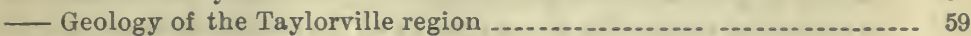

_ Cretaceous and early Tertiary of Northern California ............... 59

- Shasta-Chico series .... _._.

- Revolution in the topography of the Pacific Coast since the auriferous period ... . .

Dunbar, Romance of the age, etc.

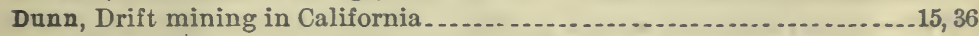

The auriferous conglomerates in California ...

Dutton, Latest volcanic eruptions in United States . . . . . . . . . . . . . . 77

Dwinelle, Acquisition of California . .

Earthquakes, Recent shocks in California-Blake _.....

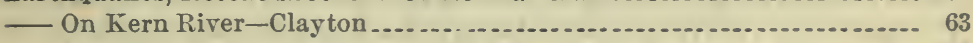

_ Remarks on recent earthquake wave-Davidson .................... 64

- Recorded earthquakes in California-Holden . . . . . . . . . . . . . . . . . 19

_. In California-Keeler. ... _... .

California earthquakes-Shaler _... $\ldots \ldots \ldots \ldots \ldots 1$

- In California from 1800-63-Trask .

— In California, 1858-59-Trask _ . _ . .

- In California from 1800 to 1861 -Trask _...

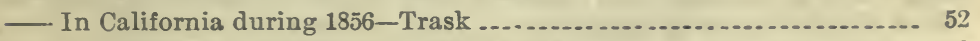

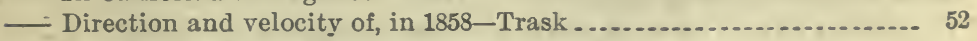

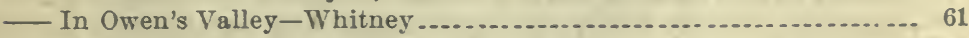

On tides and earthquakes, etc. - Winslow . $\ldots \ldots \ldots \ldots \ldots \ldots \ldots . . . .61$

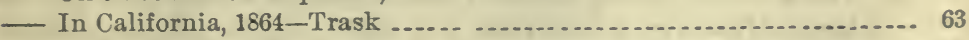

- In California, 1865-Trask ............... . .

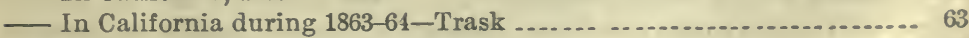

Edman, Geological account of Plumas County . _...

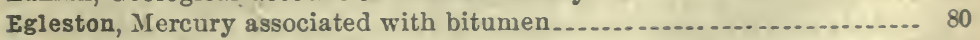

Ehrenberg, Infusoria in California _... . . . . .

Eisen, Explorations in the cape region of Baja California... ........... 34

Elmore, Esmeralda mining map .... . . . . . .

Emmons, Orographic movements of the Rocky Mountains _............. 58

Geological sketch of Lower California.... .........................34,60

Emory, Reconnoissance from Santa Fé to San Diego..................... 25

— United States and Mexican Boundary Survey ....................... 29

Evans, Geo. M., History of the discovery of gold in California .......... 69 
Evans, A. S., A la California sketch of life in the Gold State

Fairbanks, Geology of the Mother Lode region.

— Stratigraphy of the California Coast Ranges........................ 70

Geology and mineralogy of Shasta County ......................... 16

- Notes on geology and mineralogy of Tehama, Colusa, Lake, and Napa

Counties.......................................................... 17

Report on San Bernardino County ................................ 17

Mineral deposits of Inyo, Mono, and Alpine Counties .............. 17

- Geology of Ventura, Santa Barbara, San Luis Obispo, Monterey, and

San Benito Counties

Analcite diabase from San Luis Obispo County ..................... 17

Geology of the Mother Lode gold belt................................ 49

_ Pre-Cretaceous age of the metamorphic rocks of Coast Range ....... 49

- Notes on Mesozoic and Palæozoic of Shasta County ................ .. 49

- Notes on geology of eastern California ............................ 49

_ Mineral deposits of eastern California ............................ 49

— Validity of the so-called Wallala beds.... . ........................... 57

- Review of our knowledge of the geology of the California coast..... 60

— The geology of Point Sal ........................................... 24

Farnhan, Life and adventures and travels in California................ 91

Fedix, Les côtes des Pacifique ........................................... 91

Ferry, Description de la nouvelle Californie .............................. 92

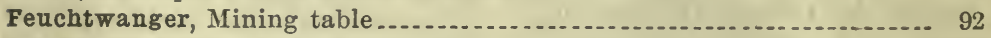

Fewkes, Santa Barbara Channel ....

Finch, Infusorial earth at Santa Barbara ............................... 76

Fortune, Report of Trinidad Copper Mining Company .................. 92

Foster, Gold region of California ................................. 92

Frazer, Report on minerals to General Smith ............................. 26

Fremont, Report of exploring expedition to the Rocky Mountains, 1842-44 25

- Map of Oregon and California, 1848 ..... ............................. 25

— Notes of travels in California ...................................... 92

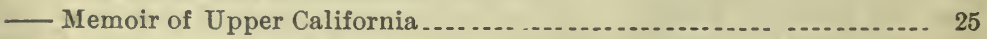

Friedrich, Silicified wood from California ............................ 71

Frignet, La Californie histoire ...................................... 92

Frost, History of California ......................... 92

Frowd-Player, Six months in California ........................... 100

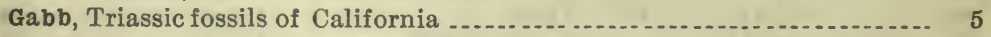

- Report on coal mines of the West Coast........................... 33

- American Tertiary fossils and new carboniferous cephalopod from Texas .......................................................... 74

Cretaceous fossils from California ................................... 6,10

Cretaceous and Tertiary fossils ..................................... 8

Notes on the geology of Lower California .......................... 12

Geographical and physical features of Lower California ............. 34

— Reply to Mr. Conrad's criticism, 1860 ............................. 46

— Description of some Secondary fossils from the Pacific ............. 47

- Subdivisions of the Cretaceous rocks in California ..................53, 63

— Notes on some fossils from gold-bearing slates.................... 63

— San I uis Obispo quicksilver fossils............................... 63

Gannet, Dictionary of altitudes in United States ..................... 42

Geology of California, the supply of silver and gold ................... 92

Gilbert, Report on geology of portions of Nevada, Utah, California, and Arizona .................................................. '38 
Page

Stages of geologic history of Sierra Nevada...................... 72

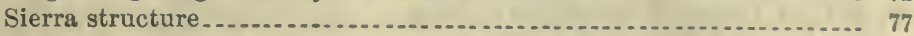

Gilpin, The central gold region

Goddard, Report on the old Carson and Johnson immigrant roads ...... 3

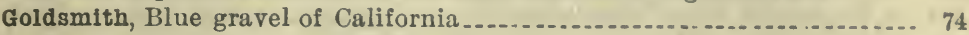

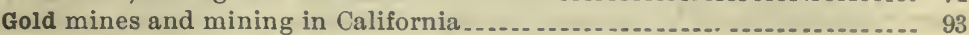

Goodyear, Description of Monte Diablo coal field...................... 12

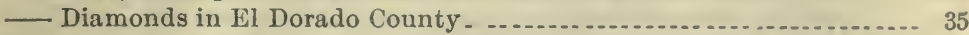

Coal mines of the western coast of United States ................... 93

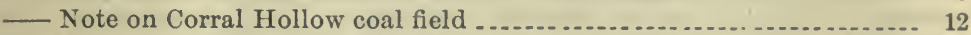

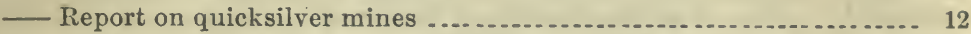

- On petroleum, asphaltum, and natural gas of Califoruia ........... 15

- Report on counties in California, $1888 \ldots \ldots \ldots \ldots \ldots \ldots \ldots . . . .15$

_ Report on San Diego County _. _...

$\longrightarrow$ Notes on the geology of the coast of Oregon . .

- Notes on the high Sierra south of Mount Whitney.................. 64

Gray, Gamopetalæ, Botany, Vol. I. ... _.

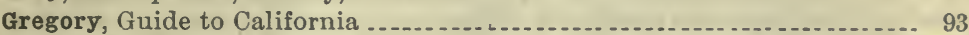

Grewingk, Beitrag zur kenntniss geognostischen Beschaffenheit Californiens .... . .

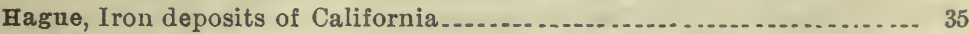

Hall, Report on geology and palæontology of Mexican boundary ........ 28

Hammond, Auriferous gravels of California _... ...

Hanks, Reports of State Mineralogist...

- Placer gold in California . . _ _ _ _ .

Borax deposits of California . . . . . . . . . . . .

Address before California Geological Society _...

- Catalogue of minerals, ores, rocks, and fossils of Pacific Coast....... 93

On the occurrence of Hanksite in California _ _ _ _

Coal and iron interest of the Pacific Coast._.

Notes on mica ........

- Deep placers of California _..._.

— Magnesia and its base and compounds _..... . .

Hardenburg, California gold mines _.

Harkness, Cinder cone age of eruption

Harris, Correlations of Tejon deposits with Atlantic stages of Gulf slope_ 77

Hart, T. s., Notes on Almaden mine . .

Hart, A., Mining statutes of United States and California . . . . . . . . . 94

Harvey, Contribution to ethnology and geology of the Pacific Slope...... 13

Hastings, Descriptions of Oregon and California _. . . . . . . . .

Hayden, Twelfth Annual Report of the Geological Survey of Territories.. 39

Heilprin, Occurrence of ammonites in the Tertiary ................... 75

Age of the Tejon rocks of California .....

Age of the Tejon rocks of California, and occurrence of ammonitic

remains in Tertiary _. .

Helper, Land of gold .......... 91

Hilgard, Report on agricultural features of California .

Agriculture and late Quaternary geology _.......... 77

Hittell, Resources of California.

- Dead rivers of California..._.

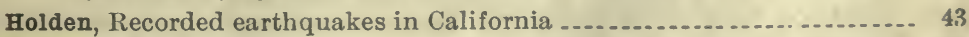

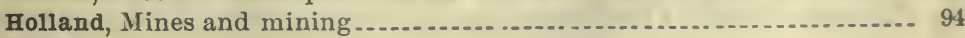


Huntley, California, its gold and its inhabitants

Huse, Resources of Santa Barbara City and County. Hutchings, Scenes of wonder in California ..............................

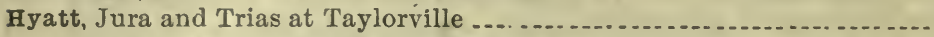
Trias and Jura in the Western States .............................. 59

Irelan, Reports of State Mineralogist_................................. 15

Isherwood, Report on brown coal from Mount Diablo.................... 29 - Experiments on various coals to ascertain their potential and economic vaporizations ........................................... 69

Jackson, A. W., Building-stones of California ........................... 15, 20

Jackson, C. T., Oil interest of Southern California...................... 95

Jackson, —, Map of mining districts of California ..................... 95

Janin, Mining and metallurgy of quicksilver.......................... 35

Jenney, Notes on dry lakes of Nevada and California.................. 78

Johnson, A. R., Expedition from Santa Fé to San Diego, 1848 ........... 26

Johnson, W. D., Report on clays ......................................... 16

Johnson, T. T., Oregon and California ................................ 95

Jones, Coal of Pacific Slope.............................................. 38

Keeler, Earthquakes in California, 1890 ................................ 42

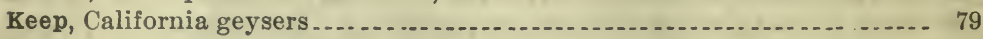

Kellogg, Forest trees of California ................................... 13

Kelly, Excursion to California, etc. ............... 95

Kimball, Reports to United States Mint............................... 36

King, Clarence, Mountaineering in the Sierra Nevada ................ 95

- Report of Sierra Iron and Mining Company ........................ 35

- Discovery of actual glaciers on the mountains of the Pacific Slope.- 53

King, T. Butler, Report on California, $1850 \ldots \ldots \ldots$

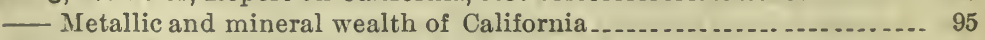

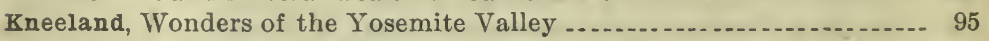

Kustel, Concentration of all kinds of ores ............................ 95

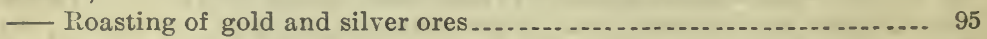

- Nevada and California processes of gold and silver extraction....... 95

Lansweert, Mineral waters from Red Bluff........................... 62

Laur, Production des metaux precieux en Californie................... 95

Du gisement et l'exploitation de l'or en Californie.................. 95

Terrains auriferous de la Californie .............................. 96

Lawson, Geology of Carmelo Bay ...................................... 20

- Post Pliocene diastrophism of the coast of Southern California.... 20

- Geomorphogeny of the coast of Northern California................ 21

Contribution to the geology of Coast Ranges ......................41, 49

- Malignite . ...................................................... 24

Lawton, California mining

Lawver, California mines .................... ....................... 36

Le Conte, Critical periods in the history of the earth ................. 21

Flora of coast islands of California.............................48, 56

Elements of geology ................................................. 96

Address before American Association for the $\Lambda$ dvancement of

Science..................................................... 45

On nomenclature of Cenozoic formations ......................... 48

Volcanic springs in desert of Colorado .............................. 51

On some ancient glaciers of the Sierra .......................... 65

Great lava flood of the northwest ...............................54, 64

- Ancient glaciers of the Sierra ............................... 54,65 
Le Conte, Prairie mounds of California and Oregon .................. 71

Theory of formation of great features of the earth's surface........ 53

— Reply to Prof. T. Sterry Hunt ...................................... 53

- On lava flood of the west, and structure of the Cascade Mountains.- 64

- Ancient glaciers of Sierra Nevada in Lake Valley ................... 54

- Formation of coast ranges ........................................ 54

Structure and origin of mountains ................................. 55

- Volcanoes about Lake Mono ........................................ 55

- Mono volcanoes are relation to glacial epoch ........................ 55

- Evidence of horizontal crushing in formation of Coast Range of

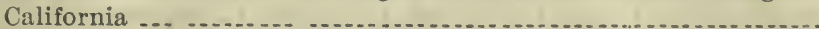

- Old river-beds of California ...........................................

— Clay and marl deposits ..............................................

Metalliferous vein formation at Sulphur Bank .....................

- Mineral vein formation at Steamboat Springs .......................

Genesis of metalliferous veins ........................................

Tertiary elevation of the Sierra Nevada ............................. 56

On the original of normal faults ...

- Tertiary and Post Tertiary changes in the Atlantic and Pacific coasts. 58

Leech, Reports to United States Mint. .............................. 36

Leidy, Elotherium in California ....................................... 74

— Vertebrate fossils from auriferous gravels .............. . . . . . . . ... 74

On mastodon remains ............................................. 74

Extinct mammals from California .........

- Extinct mammalian fauna of Dakota and Nebraska ............... 75

Lesquereux, Report on fossil plants of the auriferous gravels............ 12

- Fossil plants of Recent formations................................. 52

Levassur, Les mines de Californie et d'Australie........................ 96

Levy, Les français en Californie....................................... 96

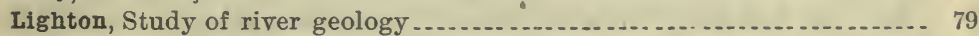

Lindgren; Notes on geology of Baja California ......................... 66

— Gold and silver veins of Ophir .................................. 41

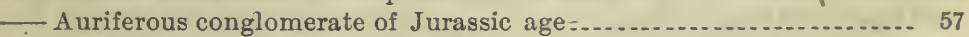

- Two Neocene rivers of California . ................................ 59

- Characteristic features of California gold quartz veins .............. 60

- Silver mines of Calico, California ................................. 80

Lock, Gold, its occurrence ........................................... 96

Loew, Geology and mineralogical character of Southern California....... 38

Lopateck, Gypsum of the coast of Lower California..................... 78

Lower California, Notes on the geology of Baja California, by W.Lindgren .34, 66

_ Geological sketch of Lower California, by S. I. Emmons .............34,60

_ Geographical and physical features, by W. M. Gabb..... ........... 34

- Explorations in the cape region of Baja California, by Gustar Eisen .......................................................... 34

Some geological notes in Emory's Mexican Boundary Survey ....... 28

Notes on the geology of Lower California, by W. M. Gabb ..........
Geological sketches of Lower California, by Merrill ................. 60

— Gold field of, by Orcutt ............................................. 79

- Eruptive rocks of, by Ritter ....................................... 67

Iyman, Mines of cinnabar in Upper California ..................... 50

Observations on California, 1848 ................................. 50

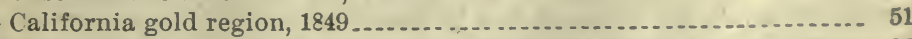

McFarlane, The coal regions of America ............................. 96 
McGarrahan, The quicksilver mines of Pinoche

McGillivray, Old river-beds of the Sierra Nevada

Mallet, Catalogue of earthquales

mallet, Catalogue of earthquakes ....................................... 68

Man

Map of region adjacent to the Bay of $\operatorname{san}$ Francisco

- American River ..................................................... 27

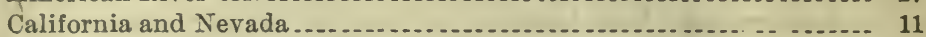

— Geological map of United States................................. 35

— Sacramento district ............................................... 44

- Topographical map of the mineral districts of California .. ......... 103

— Smartsville ... ....................................................... 44

- Marysville ............................................................... 44

— Lassen Peak........................................................ 44

— Jackson .............................................................. 44

Marcou, Geological reconnoissance from Napoleon to Los Angeles, 1855 ... 29

- Report on gèology of Southern California, 1876 ..................... 38

- Note sur les geologie de la Californie.............................. 68

- Untersuchungen in Californien ..................................... 68

_ Gisements de l'or en Californie....................................... 68

- Mittheilungen iiber die geol. Californiens ............................. 68

- American geological classification and nomenclature ............... 96

— Geology of North America .......................................... 96

Marsh, Notice o $i$ fossil forest in Tertiary of California ................. 53

Maryat, Mountain and mole hills......................................... 97

Masoh, Letter on the discovery of gold in California ..................... 27

Meek, Carboniferous and Jurassic fossils............................... 5

— Jurassic fossils of California ......................................... 6,10

— Cretaceous fossils from Vancouver and Sucia Islands ............... 74

Description of fossils from Cretaceous of Vancouver Island ......... 79

Memorial of the New Idria Mining Company ............................. 97

Merriam, List of type specimens of fossils in State University Museum .. 21

— Sigmogomphius LeContei ............................................. 24

- Reptilian remains from Triassic of Northern California ............ 57

Merrill, Geological sketch of Lower California............................ 60

Mills, Stratigraphy and succession of rocks of the Sierra Nevada ........ 59

Mines and mining in El Dorado County ................................ 98

Mining debris in California, reports on ................................. 28

— In California rivers................................................ 28

Mofras, Exploration des Territorie de l'Oregon, etc.................... 98

Moltior, Essay on California gold ..................................... 98

Mowry, The mines of the west ...................................... 98

Muir, Studies in formation of mountains in the Sierra Nevada .......... 45

— On actual glaciers in California ................................54, 72

— Living glaciers of California .................................... 98

Murchison, Siluria ..................................................... 99

Newberry, Reports on geology of California. I. R. Reports, Vol. VI.... 31

- Supposed Tertiary ammonites................................... 75

Genesis and distribution of gold ............................... 78

Nordhoff, California for health, pleasure, residence, etc................. 99

old River-Bed Gold Mining Company, Report, $1879 \ldots . . . . . . . . . . . . . . . . .99$

Orcutt, Minerals and mines of San Diego............................ 78

— Gold fields of Lower California .................................. 79 
Orcutt, Notes on Tertiary fossils from San Diego.......... . . . . . . . . . 79

_. Notes on Tertiary fossils from wells at San Diego .................. 79

Ord, Lieutenant, Report to General Riley . . . . . . . . . . . . . . . . . . . ... 27

Oregon and California, Account of gold regions, method of testing gold. 99

Paciflc Coast mines .... . . . . .

— Petroleum Company lands, San Luis Obispo ..... . . . . . . . . . . . . ... 99

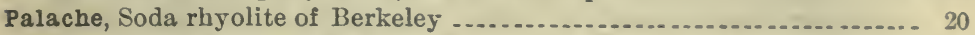

Lherzolite-serpentine of Potrero.... _....

Palmer, Report of surveys across the continent.................... 99

Parke, Captain, Explorations in California. P. R. Report, Vol. VII ..... 32

Parker, Asphaltum ....

- Infusorial earth of California _...

Patton, Geology of Calaveras County ...

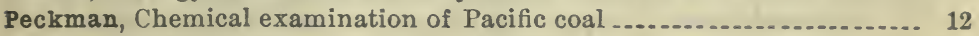

- Origin of bitumen . _.

- Examination of bituminous substances of Southern California ..... 12

- Petroleum in Southern California ....

Perrine, Earthquakes in California _... . .

Pfeiffer, Sketch map of Forest Home and Willow Spring Copper Mining

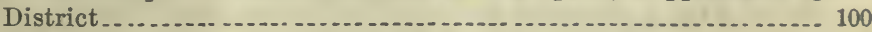

Phillips, J. A., Chemical geology of gold field of California............. 100

Contribution to the history of mineral veins . . . . . . . . . . . . . . . 53,67

- Mining and metallurgy of gold and silver ... . . . . .

_ Gold mining and gold discovery since $1851 \ldots \ldots 0$

Phillips, J. S., Explorers' and assayers' companion . . . . . . . 100

Piute Mining Company, Report, 1869 .

Preston, E. B., Report on Los Angeles County .

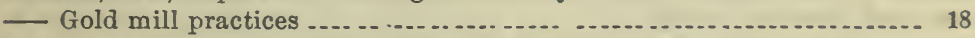

Preston, R. E., Reports as Director of United States Mint. ... ........... 36

Pumpelly, Relation of secular rock disintegration to Loess glacial drift .- 55

Quicksilver, Cinnabar at Point Reyes . . . . . . . 71

Report of Sulphur Bank Mining Company ....................... 83

- Geology of, Becker._...

- Summary of Pacific Coast deposits _.

— Sur les mines de New Almaden . . .

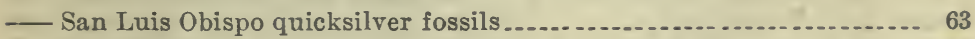

_ Report on quicksilver mines-Goodyear.......... 12

- Mines of Panoche ._. . .

- Facts concerning mines in Santa Clara .

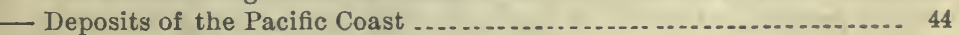

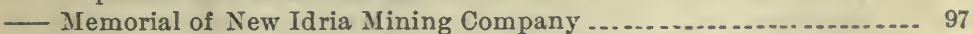

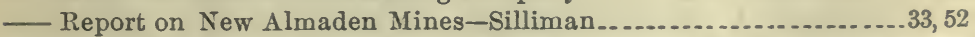

Randol, report on quicksilver ......

Ramos, Exploradora de la Baja California _..... 100

Randall, Report of special committee in favor of geological survey of the State

Randol, Report on quicksilver....

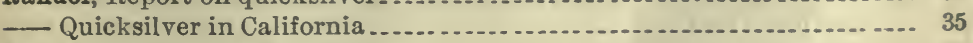

Randolph, History of California _ . . .

Ransome, Eruptive rocks at Point Bonita......... 20

Geology of Angel Island .............. 20

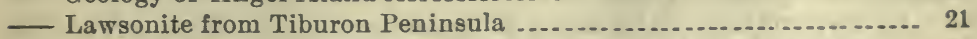

- Great Valley of California; a criticism of the theory of isostasy .... 24 
Raven, Golden dreams and leaden realities, etc.

Page:

Raymond, Notes on California, 1869 .......

- Production of gold and silver in United States . . . . . . . . . . . . . . . 79

Reger, Zwei profile durch die Sierra Nevada _ . . . . . . . . . . . . . . . . . 67

Remond, Quartz mines and mills of Mariposa and Tuolumne Counties... 4

- Description of two new species of bivalved shells from Tertiary of

Contra Costa County ..... . - . . . . 62

- Description of four new species of Echinodermata from Contra Costa .... . .

Report of an exploration and survey of the coal mines of Monte

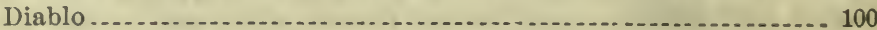

Report on Pacific wagon roads, 1858....

- Of the Director of the Mint upon the product of the precious metals in United States.

Revere, A tour in California, including a description of the gold region, etc. 1. . n

Richthofen, Natural system of volcanic rocks. . . . .

Ridgeway, The water-birds of North America . . . . . . . . . . . . . . . . . 12

Riley, Report of General Riley, 1850_..

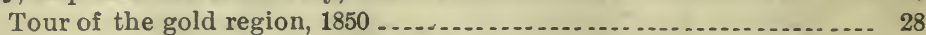

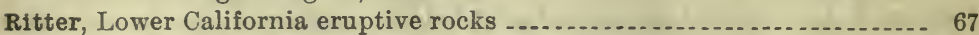

Robinson, Fayett, California and the gold regions, etc. ................. 100

Robinson, F. W., Notes on hydraulic mining . . . . . . . . . . . . . . . . 13

Rowell, List of printed maps of California.....

Russell, Quaternary history of Mono Valley ..... . . . . . . . . . . . . . . 40

- Notes on faults of the Great Basin . . . . .

Ruxton, Life in the far west, 1859...... .

Scheidel, Cyanide process .... . . .

Schuchert, Directions for collecting and preparing fossils .............. 76

Schuster, Mikroskopische beobachtungen an Californischen gesteinen ... 68

Seyd, California and its resources _ . .

Seymour, Emigrant's guide to the gold mines ...... . . . . . .

shaler, California earthquakes . ...

shaw, Golden dreams and waking realities, etc. ...................... 101

shepherd, Geysers of California .... .

Shinn, C. H., Mining camps ... . .

shumard, Description of Tertiary fossils from Oregon and Washington, and Cretaceous of Vancouver Island .............. . ............ 77

silliman, On naphtha and illuminating oil from California _............. 52

- On probable existence of microscopic diamonds in sands of hydraulic washings .... . . .

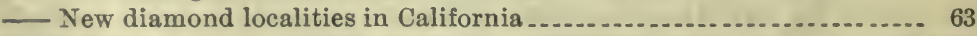

_ Report on New Almaden quicksilver mines . ... . . . . . . . . . . . . . . . .33, 52

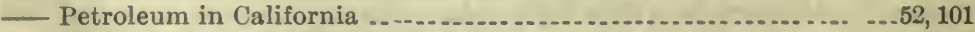

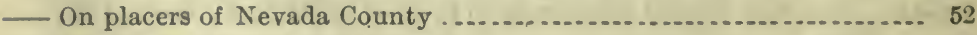

_- Petroleum regions in California ...... .

- Report on oil property of Philadelphia and California Petroleum

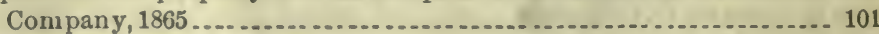

On petroleum in California .............

siversmith, Metallic wealth of Pacific States ........................ 101

Simonin, Auriferes de la Mariposa .... ................................. 67

_L La vie Souterrain, ou les mines et les mineurs . . . . . . . . . . . . . . . . . .. 101

_- Geologie, observation sur les gesements auriferes .... .............. 67 
Page.

Simpson, Emigrant's guide to the gold mines.......................... 102

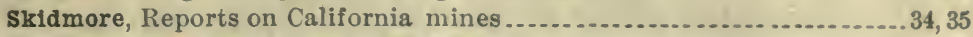

- Deep placer mining in California . . . . . . . . . . . . . . . . . . . . . . . ... 34

Smith, - , Report of General Smith on California, 1849................ 26

Smith, James P., Age of auriferous slates of the Sierra Nevada.......... 59

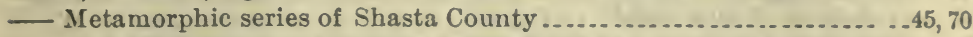

The Arkansas coal measures, in their relation to the Pacific carbon-

iferous province.................................................... 70

Supplementary notes on the metamorphic series of the Shasta region . 45

Mesozoic changes in the faunal geography of California ........... 70

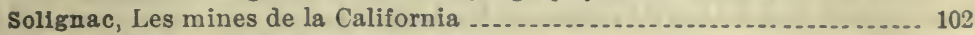

Stanton, Notes on geology of coast ranges ...

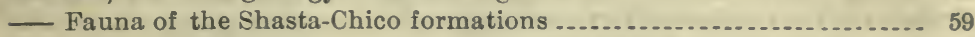

- Shasta-Chico series ........................

Cretaceous palæontology, Knoxville beds .................. ....... 43

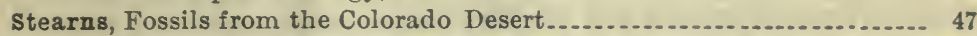

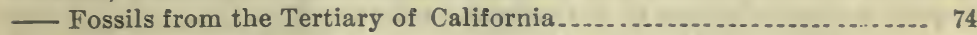

Cerripide of California _ .

Stein, Translation of the future of silver, by Edward Suess .............. 29

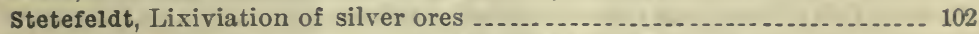

Stewart, Lecture on mineral resources of the Pacific States ............. 102

Stillman, Seeking the Golden Fleece......

Stone, Gold and silver mines of America ............ . . . . . . . . . . . . . . 102

Storms, Ancient channel system of Calaveras County ................. 17

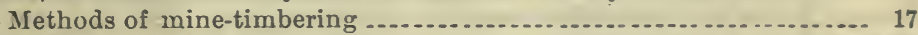

Talbot, Report of Lieutenant Talbot to General Smith, $1849 \ldots \ldots \ldots$

Taylor, Bayard, El Dorado, etc. . . . . . . . . . . .

Taylor, J. W., Condition of gold and silver mining on Pacific Slope, 1867.- 33

Copper resources of Pacific Slope, 1867 . . . . . . . . . . . . . . . . . . . . . 33

Taylor, R. C., Statistics of coal ....

Tegoborski, Essay on the effect of the discovery of gold in California and

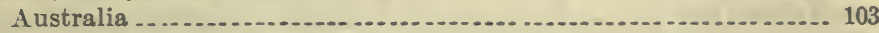

Thornton, Oregon and California in $1848 \ldots \ldots 3$

Trask, Earthquakes in California, from 1800 to $1863 . \ldots \ldots . . . . . . . . . . . . .103$

_- Geology of the Sierra Nevada or California Range................... $1,70$.

- Mineral districts of Central California . . . . . . . . . . . . .

Report on State Geological Survey _.

Description of three new species of the genus Plagiostoma from the Cretaceous ...............

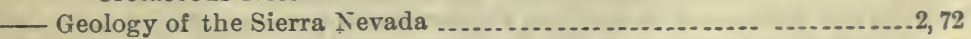

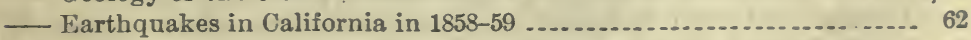

Geology of coast mountains _.....

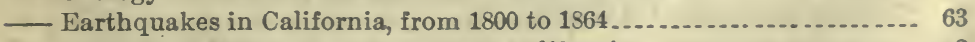

- Geology of Northern and Southern California . . . . . . . . . . . . . . ... 2

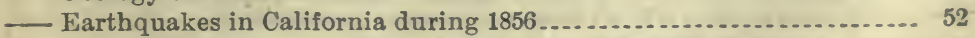

_ Direction and velocity of earthquakes in California, 1857 ......... 52

_ Description of Ammonites Batesi . . . . . . . . . . . . . . . . . . . . . . . .... 61

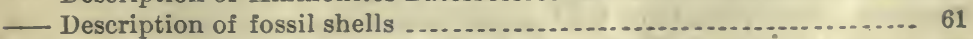

- On earthquakes in California, from 1812 to $1857 \ldots \ldots \ldots \ldots \ldots \ldots . . \ldots \ldots$

_ Two new species of Ammonites and Baculite...................... 62

- Topographical map of the mineral districts of California ......... 103.

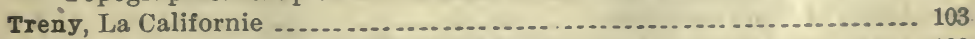

Trip, Report on Sonoma-Pacific coal mines . . . . . . . . . . . . . . . . . . . . 103. 
Turner, Rocks of the Sierra Nevada

Page.

Contribution to the geology of California ........................... 49

Geological notes on the Sierra Nevada, parts 1 and $2 \ldots . . . . . . . . . . . .49$

- Notes on geology of the coast ranges................................ 49

Auriferous gravels of the Sierra Nevada ........................... 49

- Geology of Mount Diablo .......................................... 59

The age and succession of the igneous rocks of the Sierra Nevada... 70

Turrill, California notes.................................................... 104

Twining, Report on Union and Central Pacific Railways ............... 28

Tyson, P. T., Geology of California....................................... 26

Geology and industrial resources of California.................... 27

Tyson, J. L., Diary in California ............................................ 104

Veatch, On mud volcanoes in Colorado Desert.........................62, 104

- On earthquakes in San Francisco ................................... 71

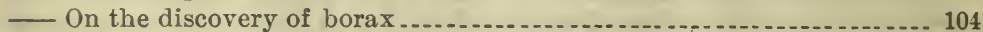

Vinton, Report on artesian well near Benicia .......................... 27

Vogdes, Geological survey in the State of California...................... 66

On the discovery of Proetus ellipticus in Shasta County ............. 66, 80

Walbridge, Fossil ferns ............................................. 79

Walcott, Lower Cambrian rocks in eastern California .................. 57

Waldeyer, Hydraulic mining in California ............................. 35

Walton, Facts from the gold region ...................................... 104

Warner, Reconnoissance of a route through the Sierra Nevada, by the

Upper Sacramento ................................................ 27

Wasson, Bodie and Esmeralda, etc.......................................... 104

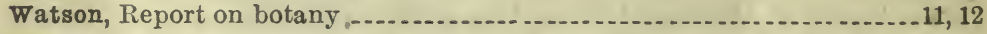

watts, The gas and petroleum-yielding formation of the central valley of California ...................................................... 17

Weber, Petroleum and asphaltum of Northern California ............... 15

Report on Santa Clara County ..................................... 16

Weeks, Petroleum ...................................................... 38,41

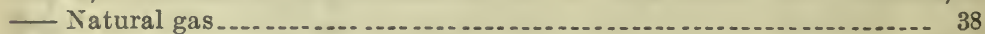

Wells, How we get gold in California .................................... 104

Werth, Dissertation on the resources and policy of California ............ 104

Weston, Four months in the mines of California ....................... 104

Wheeler, Report of surveys west of the 100th meridian.................. 38

White, Description of Productus giganteus ................................ 39

— Report on Mesozoic invertebrates................................... 39

— Mesozoic and Cenozoic palæontology of California .................. 41

- On new Cretaceous fossils from California ............................ 42

— Remarks on the genus Aucella ...................................... 44

_ Fossils from the Pacific Coast .......................................... 42

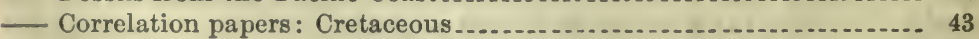

Mountain upthrust................................................... 47

_ Notes on occurrence of Productus giganteus in California ........... 76

— North American Mesozoic .............................................. 77

Whiting, Report on Mono County .................................... 15

Whitney, Metallic wealth of the United States ... ...................... 104

- Letter of Professor Whitney on the Mariposa estate ................. 105

- Address delivered before Legislature ................................ 3,4

- Notice of a human skull from a shaft near Angels.................. 63

- Letter of State Geologist ............................................. 3,4

- Fresh-water infusorial deposits of the Pacific Coast................. 63 
Whitney, Lecture on geology ...................................... Page.

— Die Californischen Bacillarien Gebirge .......................... 67

Annual reports of State Geologist................................ 4

Yosemite guide-books ............................................ 5

- Report of progress and synopsis of field-work from 1860-64. Geology, Vol. I.

Contributions to barometric liypsometry ......................... 11

— Geology of California, Vol. II .................................. 12

Climatic changes of later geological times ......................... 13

— Report to Board of Regents, 1877 ................................. 19

— Progress of Geological Survey in California ........................ 52

- On earthquake wave of 1872 .......... ....................... 72

- Notice of explorations of Geological Survey of California in the Sierra Nevada, 1864 .................................................... 52

- On the borax in California ..................................... 52

— On the Owen's Valley earthquake ............................... 53

- Auriferous gravels of the Sierra Nevada ...... ....................... 13

Wlley, Remarks on auriferous gravel deposits of Placer County .......... 64

Williams, Reports of mineral resources of United States.................39, 44

Williamson, Reports on Pacific Railroad Surveys, Vol. V and Vol. VI ...29, 31

_ Exploration of Monte Diablo and valley ........................... 27

Wilson, On the gold regions of California ........................... 67

- Geology of the gold region of California ......................... 71

Winchell, Effects of pressure of a continental glacier................ 48

- Glacial action in flanks of higher Sierra Nevada ................... 48

Winslow, On human remains with those of the mastodon.............. 53

- On tides, earthquakes, rising of continents, etc................... 61

Lead and zinc deposits of Missouri................................. 81

Wood, Sixteen months at the gold diggings .......................... 105

Wright, The ice age in North America .............................. 105

- Note on glaciation of Pacific Coast.................................. 47

Wyld, Guide to California ................................................ 105

- Notes on distribution of gold throughout the world ................. 105

- Geographical and mineralogical notes to accompany Wyld's map of the gold regions................................................. 105

Yale, C. G., Bulletin No. 7, showing the mineral productions of California. 18 - Bulletin No. 8, showing by counties the mineral productions of California

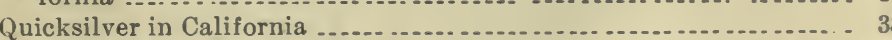

- Auriferous gravels of California

- Reports on California mining .......... ......................... 36

- Chapter on California mines, in Eleventh Census Report ........... 38

- Iron ores of Pacific Coast.......................................... 39

Yale, G., Legal titles to mining claims .................................. 105

Yates, Notes on the geology of the Channel Islands ................... 16

- The mollusca of the Channel Islands ............................. 16

- Notes on the geology and scenery of the islands of Santa Barbara

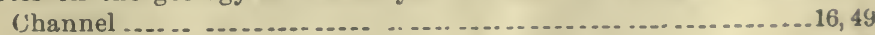

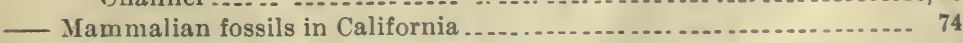

- Fossil botany ................................................... 78 


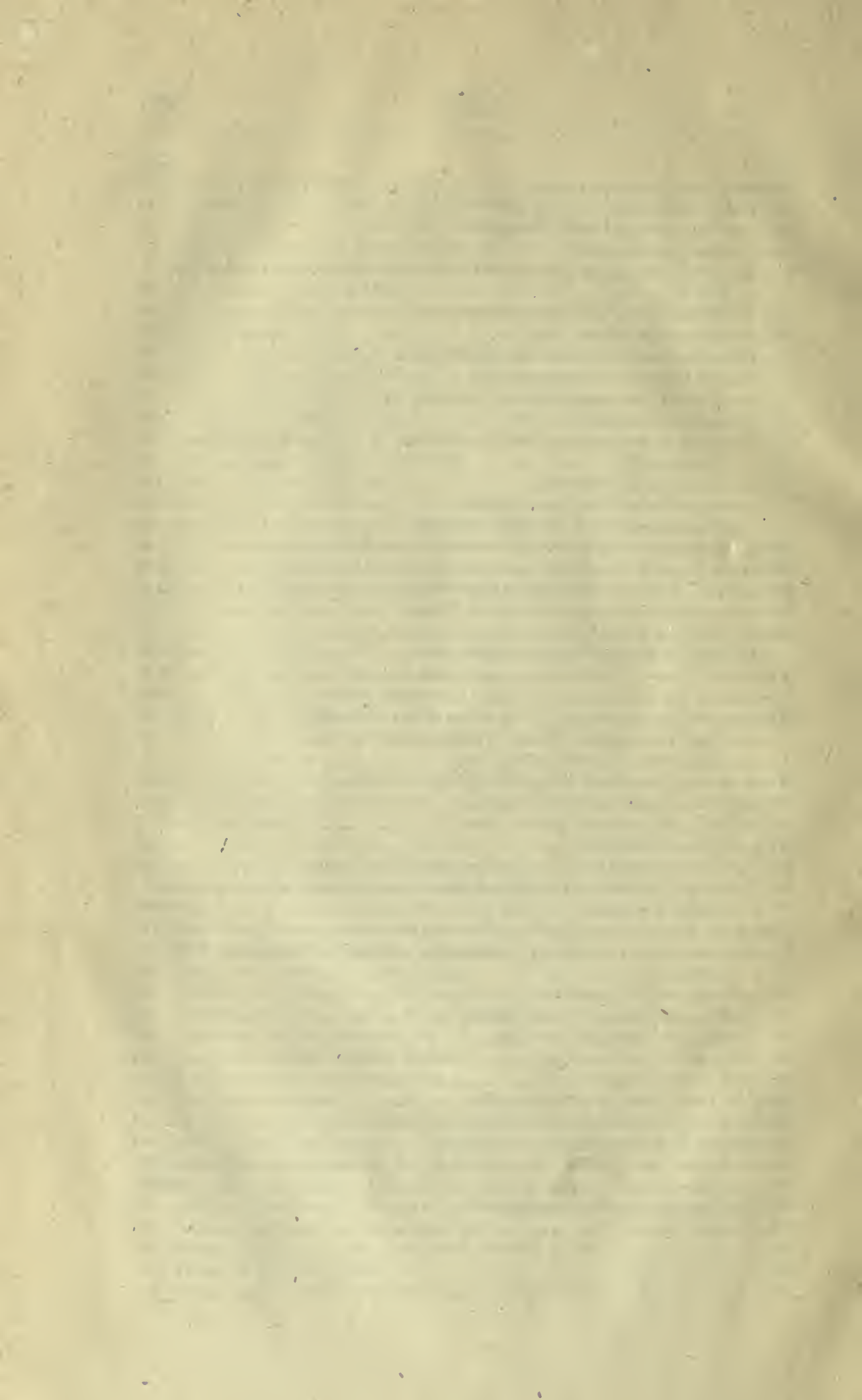




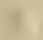



$=$ 
THIS BOOK IS DUE ON THE LAST DATE STAMPED BELOW

FEB 20 'Bz

AN INITIAL FINE OF 25 CENTS WILL. BE ASSESSED FOR FAILURE TO RETURN THIS BOOK ON THE DATE DUE. THE PENALTY WILL. INCREASE TO 50 CENTS ON THE FOURTH DAY AND TO \$1.00 ON THE SEVENTH DAY OVERDUE.

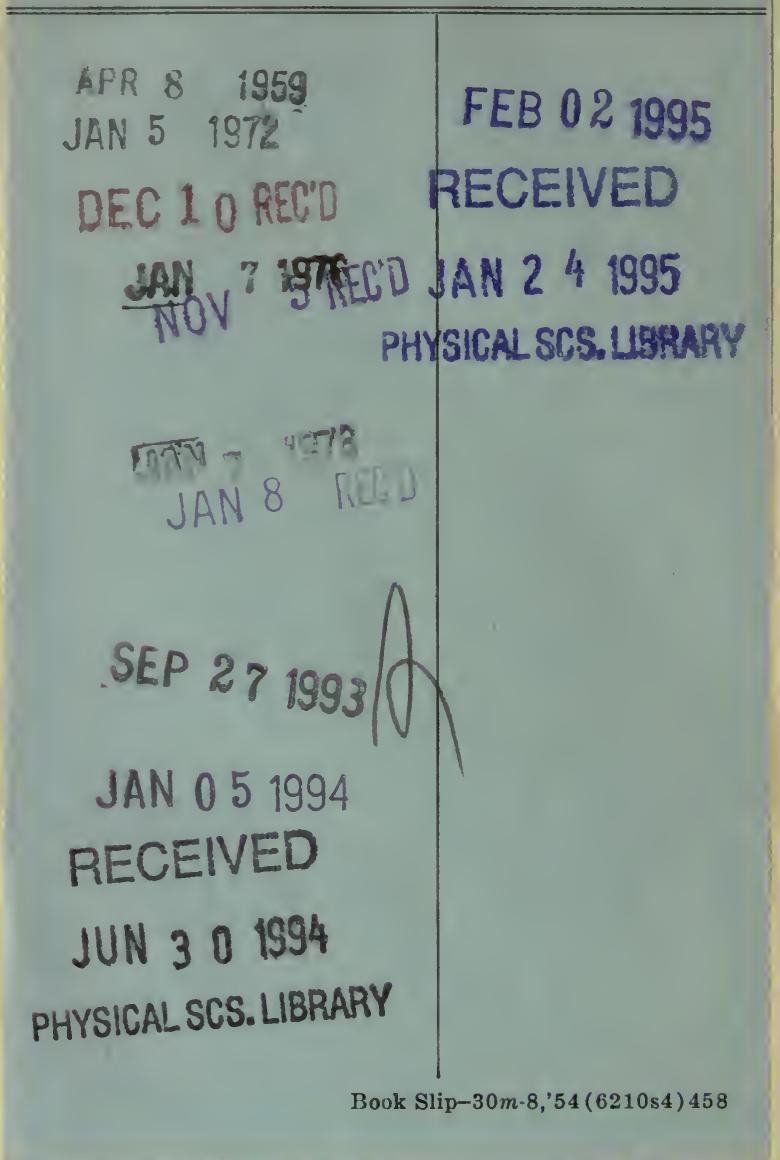

M 1 ' 65 
